\title{
CURVA DE CRESCIMENTO E ACÚMULO DE NUTRIENTES PELA CULTURA DA BATATA cv. 'ATLANTIC'
}

\author{
GLAUCIA TIEMI YORINORI
}

Dissertação apresentada à Escola Superior de Agricultura "Luiz de Queiroz", Universidade de São Paulo, para obtenção do título de Mestre em Agronomia, Área de Concentração: Solos e Nutrição de Plantas.

PIRACICABA

Estado de São Paulo - Brasil

Fevereiro - 2003 


\title{
CURVA DE CRESCIMENTO E ACÚMULO DE NUTRIENTES PELA CULTURA DA BATATA cv. 'ATLANTIC'
}

\author{
GLAUCIA TIEMI YORINORI
}

Engenheiro Agrônomo

Orientador: Prof. Dr. QUIRINO AUGUSTO DE CAMARGO CARMELLO

Dissertação apresentada à Escola Superior de Agricultura "Luiz de Queiroz", Universidade de São Paulo, para obtenção do título de Mestre em Agronomia, Área de Concentração: Solos e Nutrição de Plantas.

PIRACICABA

Estado de São Paulo - Brasil

Fevereiro - 2003 


\title{
Dados Internacionais de Catalogação na Publicação (CIP) DIVISÃO DE BIBLIOTECA E DOCUMENTAÇÃO - ESALQ/USP
}

\author{
Yorinori, Glaucia Tiemi \\ Curva de crescimento e acúmulo de nutrientes pela cultura da batata cv. 'Atlantic' / \\ Glaucia Tiemi Yorinori. - - Piracicaba, 2003. \\ 66 p. : il. \\ Dissertação (mestrado) - - Escola Superior de Agricultura Luiz de Queiroz, 2003. \\ Bibliografia.
}

1. Batata 2. Nutrientes minerais do solo 3. Safra I. Título

CDD 633.491

"Permitida a cópia total ou parcial deste documento, desde que citada a fonte - O autor" 
"A felicidade aparece para aqueles que choram.

Para aqueles que se machucam.

Para aqueles que buscam e tentam sempre.

E para aqueles que reconhecem a importância das pessoas que passam por suas vidas" Clarice Lispector 
Aos meus irmãos

Eliane e Newton e

àminha tia Toshiko

por todo o carinho,

amizade e apoio

OFEREÇO

Ao meu pai e à minha mãe (in memoriam)

Por todo o amor, apoio e incentivo DEDICO 


\section{Agradecimentos}

A Deus, por me mostrar a luz nos momentos difíceis da minha vida e por colocar no meu caminho pessoas maravilhosas quando precisei.

Ao Prof. Dr. Quirino Augusto de Camargo Carmello, pelo carinho, paciência, dedicação, orientação e amizade.

Ao Sr. Kameo Oi e ao Keko, pelas áreas cedidas e pela compreensão para a realização do trabalho.

Aos engenheiros agrônomos Mauro Ono e Paulo, pela ajuda e apoio.

Ao "Passarinho" pela compreensão e paciência durante o período das coletas.

Aos Professores Francisco Antonio Monteiro e Antonio Roque Dechen, pela convivência, amizade e aprendizado.

Ao Prof. Dr. Décio Barbin, pela ajuda na parte estatística deste trabalho.

À Prof ${ }^{a}$. Dr ${ }^{a}$. Beatriz Monte Serrat Prevedello, pelo incentivo e apoio para a realização deste Mestrado.

A todos os professores do Programa de Pós-graduação em Solos e Nutrição de Plantas por todos os conhecimentos adquiridos durante o Mestrado.

À Elma Chips, por ter financiado as análises deste experimento.

Aos engenheiros agrônomos da Divisão Agrícola da Elma Chips, pelo auxílio e apoio.

Às funcionárias do laboratório de Nutrição Mineral de Plantas: Ednéia C. S. Mondoni, Lúcia H. S. P. Forti, Lurdes A. D. de González, Nivanda M. de Moura e Sueli M. A. C. Bovi, pelo apoio e amizade.

Às amigas Aline Marques Genú e Karina Batista, um agradecimento especial por todos os momentos que passamos juntas, pelo convívio, amizade e ajuda incondicional. 
Às amigas Adriana Teramoto, Cristiaini Kano, Fernanda Forli, Adriana M. M. Pires, Ana Paula do Carmo e ao amigo Caio Fortes, muito obrigada por tudo.

A todos os amigos da salinha da pós-graduação da Nutrição Mineral de Plantas e em especial àminha xará e "irmã" Gláucia Regina Anti, pela amizade e ajuda.

Ao estagiário Tiago Pires Marques pela ajuda durante o experimento.

Aos amigos Cristiano Alberto de Andrade e Gilmar Ribeiro Natchigall pela amizade, ajuda e compreensão.

Aos amigos de graduação Fábio Prata, Robson R.M. Barizon, Márcia M. Grise, Carolina S.S. Augusto e Maristela Hikishima pela amizade e apoio nas horas difíceis que passei durante a realização deste trabalho.

A todas as pessoas que de alguma forma ajudaram na elaboração desta dissertação.

Aos meus cães e gatos, pela amizade incondicional.

Ao Conselho Nacional de Desenvolvimento Científico e Tecnológico (CNPq) pela concessão da bolsa.

À Escola Superior de Agricultura "Luiz de Queiroz" - USP e à Coordenação do Programa de Pós-Graduação em Solos e Nutrição de Plantas pela realização do curso. 


\section{SUMÁRIO}

\begin{tabular}{|c|c|}
\hline & Página \\
\hline ESUMO.......... & ix \\
\hline SUMMARY... & $x i$ \\
\hline 1 INTRODUÇÃO... & 1 \\
\hline 2 REVISÃO DE LITERATURA....... & 2 \\
\hline 2.1 Aspectos gerais da cultura da batata.................... & 2 \\
\hline 2.2 Breve histórico da batata industrializada..... & 4 \\
\hline 2.2.1 Características das cultivares destinadas àindústria....................... & 5 \\
\hline 2.3 Massa de material seco e acúmulo de nutrientes pela batateira................... & 5 \\
\hline 3 MATERIAL E MÉTODOS.... & 11 \\
\hline 3.1 Áreas experimentais.......... & 11 \\
\hline 3.1.1 Localização e características gerais das áreas experimentais.................... & 11 \\
\hline 3.1.2 Características dos solos................... & 12 \\
\hline 3.2 Calagem, preparo do solo e adubação de plantio............ & 14 \\
\hline 3.3 Plantio e espaçamento.... & 14 \\
\hline 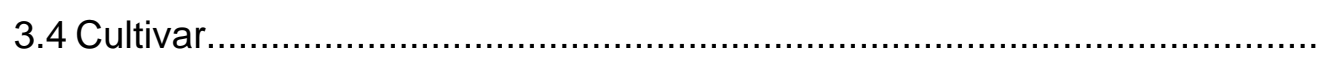 & 14 \\
\hline 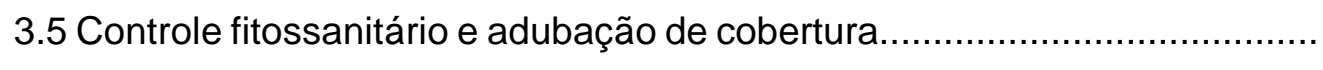 & 15 \\
\hline 3.6 Irrigação....... & 16 \\
\hline 3.7 Coleta de plantas............. & 16 \\
\hline 3.8 Preparo das amostras.................. & 17 \\
\hline 3.9 Análise química das plantas........ & 18 \\
\hline 3.10 Análise estatística.................... & 18 \\
\hline 4 RESULTADOS E DISCUSSÃO....... & 19 \\
\hline 4.1 Acúmulo de massa de material seco.............................. & 19 \\
\hline 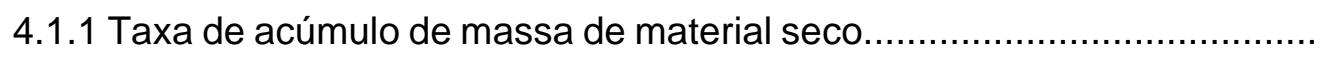 & 22 \\
\hline 2 Acúmulo e exportação de macronutrientes.... & 24 \\
\hline
\end{tabular}




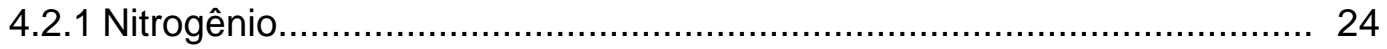

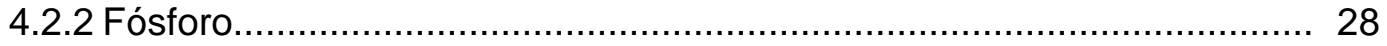

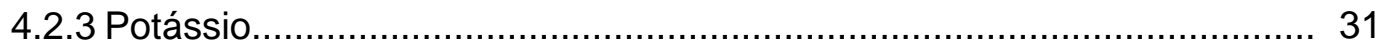

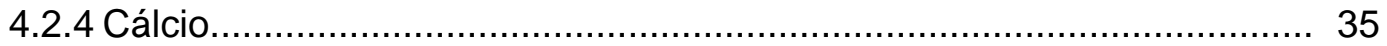

4.2.5 Magnésio............................................................................. 38

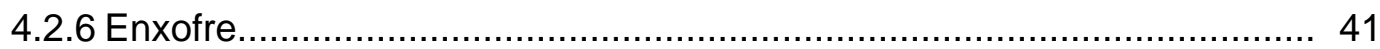

4.3 Acúmulo e exportação de micronutrientes........................................ 44

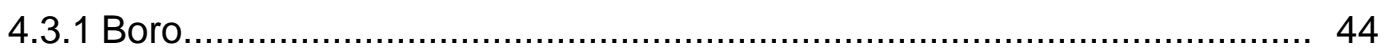

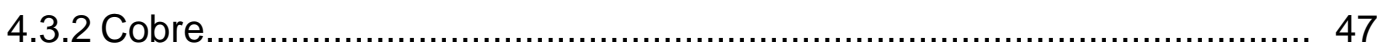

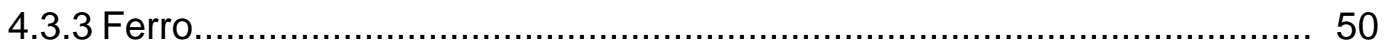

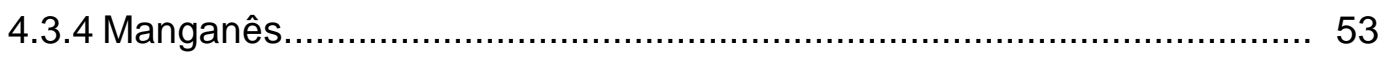

4.3 .5 Zinco........................................................................................ 56

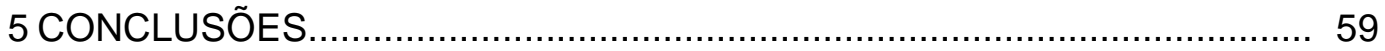

REFERÊNCIAS BIBLIOGRÁFICAS.................................................. 60 


\title{
CURVA DE CRESCIMENTO E ACÚMULO DE NUTRIENTES PELA CULTURA DA BATATA cv. 'ATLANTIC'
}

\author{
Autora: GLAUCIA TIEMI YORINORI \\ Orientador: QUIRINO AUGUSTO DE CAMARGO CARMELLO
}

\section{RESUMO}

Por apresentar elevada capacidade de produção e por ser uma das poucas cultivares adaptadas àprodução de "chips", a cultivar de batata 'Atlantic' responde por cerca de $80 \%$ do mercado brasileiro formal de batata consumida desta forma. Com os objetivos de determinar as curvas de crescimento de massa de material seco, o acúmulo máximo e a exportação de nutrientes, em lavouras comerciais, em duas safras, pela cv. 'Atlantic', realizou-se este trabalho nos períodos de setembro a dezembro de 2001(safra das águas) e de fevereiro a março de 2002 (safra da seca) em Itapetininga-SP, localizada na latitude $23^{\circ} 35^{\prime} 08^{\prime \prime} \mathrm{S}$, longitude $48^{\circ} 02^{\prime} 50^{\prime \prime} \mathrm{W}$ e com $636 \mathrm{~m}$ de altitude. Para isso, foram delimitadas quatro parcelas de $100 \mathrm{~m} \mathrm{X} 17 \mathrm{~m}$ em lavouras comerciais, das quais foram realizadas coletas semanais das plantas a partir de 20 dias após o plantio. As plantas coletadas foram separadas em raízes, caules, folhas e tubérculos e secas e pesadas para a obtenção da massa de material seco nos diferentes estádios de desenvolvimento, sendo posteriormente moídas, e submetidas àanálise para a obtenção da extração de nutrientes ao longo do ciclo. A 
análise estatística dos parâmetros avaliados foi feita considerando-se as épocas de plantio e quatro repetições.

Os resultados permitiram as seguintes conclusões: a safra das águas produziu mais massa de material seco que a safra da seca. $O$ acúmulo de massa da planta foi influenciado pelos estádios da cultura e pela safra: vegetativo (2,2 e 5,2\%) < tuberização (13 e 20\%) < enchimento de tubérculos (90 e 95\%) < maturação (100 e $100 \%$ ) para a safra das águas e da seca, respectivamente. A seqüência de acúmulo máximo na safra das águas foi: nitrogênio > potássio > cálcio > fósforo > magnésio > enxofre $>$ ferro $>$ manganês $>$ zinco $>$ boro $>$ cobre. Na safra da seca, o potássio trocou de posição com o nitrogênio e o fósforo com o cálcio. O acúmulo máximo dos nutrientes depende da safra e do nutriente: nitrogênio (140 e 119); fósforo (17,6 e15,2); potássio (134 e 139); cálcio (21,7 e 14,6); magnésio (14,3 e 6,9); enxofre (10,8 e 14,6) em kg ha-1; boro (107 e 84,3); cobre (43,5 e 38,9); ferro (1.229 e 790); manganês (250 e 130); zinco (156,6 e 124,6) em g ha-1, para as safras das águas e da seca, respectivamente. A seqüência de exportação de nutrientes pelos tubérculos na safra das águas foi: nitrogênio > potássio > fósforo > enxofre > magnésio > cálcio > ferro > zinco > boro > manganês > cobre. Na safra da seca, potássio trocou de posição nitrogênio e cobre com manganês. 


\title{
GROWTH CURVE AND NUTRIENT ACCUMULATION OF ATLANTIC POTATOES
}

\author{
Author: GLAUCIA TIEMI YORINORI \\ Adviser: Prof. Dr. QUIRINO AUGUSTO DE CAMARGO CARMELLO
}

\section{SUMMARY}

By presenting a high yield potencial and being one of the few cultivars adapted for chipping, Atlantic potatoes are responsible for approximately $80 \%$ of the brazilian formal potato chips market. With the objective of determining the growth curves, maximum nutrient accumulation and nutrient exportation, this study was carried out in Itapetininga, São Paulo State, at $23^{\circ} 35^{\prime} 08^{\prime \prime}$ S of latitude, $48^{\circ} 02^{\prime} 50^{\prime \prime}$ W of longitude and 636 meters above sea level, in two commercial areas of Atlantic potatoes from September to December 2001 (wet season), and from February to March 2002 (dry season). Four plots with $100 \mathrm{~m} \mathrm{X} 17 \mathrm{~m}$ were set in each experiment and plants were collected weekly, after 20 days from planting. The collected plants were separated in roots, stems, leaves and tubers, dried and weighted, to obtain the dry-matter at different stages of growth. Samples were ground and analized to obtain nutrients concentration and to calculate nutrients accumulations. Statistical analysis considered the season and four replications.

Results showed that wet season potatoes had higher dry-matter production than those of dry season. Nutrient accumulation was influenced by growth stage and 
season: vegetative (2.2 and 5.2\%) < tuberization (13 and 20\%) < tuber bulking (90 and $95 \%$ ) < maturation (100 and 100\%) for wet and dry season, respectively. The maximum nutrient accumulation in the wet season was: nitrogen > potassium > calcium $>$ phosphorus $>$ magnesium $>$ sulphur $>$ iron $>$ manganese $>$ zinc $>$ boron $>$ copper. During dry season, potassium changed position with nitrogen, and phosphorus with calcium. Maximum accumulation of nutrients $\left(\mathrm{kg} \mathrm{ha}^{-1}\right.$ for macronutrients and $\mathrm{g} \mathrm{ha}^{-1}$ for micronutrients) depended on the season and on the nutrient: nitrogen (140 and 119); phosphorus (17.6 and 15.2); potassium (134 and 139); calcium (21.7 and 14.6); magnesium (14.3 and 6.9); sulphur (10.8 and 14.6); boron (107 and 84.3); copper (43.5 and 38.9); iron (1229 and 790); manganese (250 and 130); zinc (156.6 and 124.6), for wet and dry season, respectively. The nutrient exportation by the tubers in the wet season was: nitrogen $>$ potassium $>$ phosphorus $>$ sulphur $>$ magnesium $>$ calcium > iron > zinc > boron > manganese > copper. In the dry season, potassium changed position with nitrogen, and copper with manganese. 


\section{INTRODUÇÃO}

A batateira é a hortaliça mais plantada no mundo e ocupa o quarto lugar entre os alimentos mais consumidos, sendo superada apenas pelo trigo, arroz e milho. No Brasil são produzidas cerca de 2,5 milhões de toneladas anuais de batata, o que corresponde, aproximadamente, ao consumo nacional. A forma mais popular de consumir batatas é através de "palitos" fritos. Em menor escala, a batata é consumida cozida, como purê, salada ou assada. Também tem-se observado o rápido aumento do consumo de batata industrializada, na forma de fatias finas fritas ("chips") ou "palitos" pequenos fritos (batata palha).

Apesar da sua importância e do grande número de pesquisas sobre a cultura, as peculiaridades de cada cultivar fazem uma grande diferença na produtividade. Os estudos existentes sobre a nutrição mineral da cultura são voltados para cultivares de consumo "in natura" e a maioria deles são bastante antigos. Com relação às cultivares para fins industriais, nas condições tropicais, as pesquisas são quase inexistentes.

Em nosso país, a cv. 'Atlantic' destaca-se e responde por cerca de $80 \%$ do mercado nacional formal de batata do tipo "chips", por ser uma das poucas cultivares adaptadas a essa finalidade e, por apresentar elevada capacidade de produção, é também a cultivar mais plantada nos Estados Unidos, para esse fim.

Sabe-se que as cultivares destinadas à indústria possuem necessidades nutricionais diferentes das utilizadas no consumo "in natura" e, a nutrição é um dos principais fatores que interferem, tanto na produtividade, quanto na qualidade da batata.

Com isso, os objetivos deste trabalho foram: determinar as curvas de crescimento de material seco em lavouras comerciais, nas safras das águas e da seca pela cultura da batata cv. 'Atlantic', de uso industrial; determinar o acúmulo máximo de nutrientes na batateira e, também, a exportação por ocasião da colheita, o que permite levar-se informações práticas para os produtores e, servir de base para os estudos futuros. 


\section{REVISÃO DE LITERATURA}

\subsection{Aspectos gerais da cultura da batata}

A batateira (Solanum tuberosum L.), também conhecida como batateira-inglesa, é nativa da Cordilheira dos Andes na América do Sul, onde foi consumida pelas populações nativas, em tempos que remontam a mais de 6.000 anos. Ela teve grande importância na cultura Inca e nas civilizações anteriores a eles (Harris, 1992). Foi introduzida na Europa por volta de 1570, através dos colonizadores espanhóis, tornando-se um alimento importante, principalmente na Inglaterra, daí a denominação batata-inglesa. Por volta de 1620, foi levada da Europa para a América do Norte, onde tornou-se um alimento popular (Lopes, 1997).

No Brasil, o cultivo mais intenso da batateira teve início da década de 1920, no cinturão verde de São Paulo (Lopes, 1997). Hoje a batata é considerada a principal hortaliça do país e é a cultura que apresenta a maior demanda relativa por fertilizantes $\left(1940 \mathrm{~kg} \mathrm{ha}^{-1}\right)$, cerca de 5,7 vezes maior do que a da soja (338 $\mathrm{kg} \mathrm{ha}^{-1}$ ) (ANDA, 2000). Anualmente, a área plantada está em torno de 150.000 ha, com produção de $2.500 .000 \mathrm{t} \mathrm{ano}^{-1} \mathrm{e}$ uma produtividade média de $16 \mathrm{t} \mathrm{ha}^{-1}$. As regiões Sul e Sudeste são as principais produtoras, contribuindo com $98,5 \%$ do total produzido (FNP, 2002).

A batateira é uma solanácea anual, que apresenta caules aéreos, herbáceos, e suas raízes originam-se na base desses caules ou hastes. O sistema radicular é delicado e superficial, com raízes concentrando-se até $30 \mathrm{~cm}$ de profundidade. Suas folhas são compostas por folíolos arredondados e as flores hermafroditas apresentamse reunidas em inflorescências no topo da planta. Predomina a autopolinização, que origina um pequeno fruto verde, que contém numerosas sementes minúsculas e viáveis (Filgueira, 2000). 
A batateira tolera uma acidez moderada, produzindo bem na faixa de $\mathrm{pH} \mathrm{5,0} \mathrm{a}$ 6,5. Acima dessa faixa, pode ocorrer susceptibilidade dos tubérculos a certos patógenos do solo, como agentes da sarna comum (Streptomyces scabies) e da murcha-bacteriana (Pseudomonas solanacearum). Solos com textura média, leves, arejados e bem drenados, ricos em matéria orgânica e com saturação por alumínio abaixo de $20 \%$ são os mais favoráveis ao desenvolvimento dos tubérculos (Kleinkopf et al., 1981; Manrique, 1992). A batateira é moderadamente tolerante àsalinidade do solo e ocorre uma diminuição na produtividade, com valores acima de 1,7 dS $\mathrm{m}^{-1}$ (Maas \& Hoffman, 1977).

A cultura da batateira é classificada como uma cultura de clima temperado, porém cresce nas regiões tropicais, com altitude elevada. As maiores produtividades são obtidas nos países onde os dias duram de 13 a 17 horas na época de tuberização, com temperaturas médias entre 15 e $18^{\circ} \mathrm{C}$ e com irrigação (Haeder \& Beringer, 1983). A cultura é muito sensível ao estresse hídrico, sendo necessário, portanto, o fornecimento adequado de água, desde o início da tuberização até a maturidade (Loom, 1981; Hang \& Miller, 1986). As exigências climáticas da cultura são peculiares e precisas, ressaltando-se que o fator limitante é a temperatura elevada, especialmente a temperatura noturna, pois quando esta se mantém acima de $20^{\circ} \mathrm{C}$ durante 60 noites ou mais, não ocorre a tuberização (Ewing, 1997).

No centro-sul do país, distinguem-se três épocas características de plantio: o plantio das águas, realizado de setembro a novembro, que é praticado em larga escala, nas regiões mais altas, onde a elevação da temperatura e o alongamento do fotoperíodo durante o ciclo resultam em crescimento exagerado da parte aérea, o que provoca o acamamento da planta, tornando os folíolos menores e retardando a tuberização. Ele responde por 55\% da safra (Filgueira, 2000).

O plantio da seca, realizado de fevereiro a abril, que é praticado em altitudes medianas, quando a temperatura e o fotoperíodo diminuem ao longo do ciclo, o que estimula a tuberização e o crescimento dos tubérculos, ele é responsável por $32 \%$ da safra e, o plantio de inverno, realizado de maio a julho, que é praticado em altitudes variadas, onde o inverno é suave e livre de geadas, quando a temperatura e o fotoperíodo mantêm-se favoráveis ao longo do ciclo. Ele responde por $13 \%$ da safra nacional (Filgueira, 2000). 


\subsection{Breve histórico da batata industrializada}

Desde o tempo dos Incas, o homem desidrata as batatas para facilitar o armazenamento e aumentar sua durabilidade, servindo como alimento para os guerreiros. Isso era feito deixando-as congelarem durante a noite e descongelarem durante o dia. O suco era então espremido por meio de pisoteio, a operação era repetida inúmeras vezes, até que a umidade fosse reduzida a um ponto conveniente para o armazenamento (Pereira, 1987).

Após os espanhóis terem levado a batata para a Europa, os processos de desidratação tornaram-se mais sofisticados. Durante a Revolução Industrial, foram criados na Alemanha e na Inglaterra, processos de secagem de batata fatiada, extrusada e de purê de batata em superfícies aquecidas. Durante o século XIX, surgiram novos processos de industrialização, como a fermentação da batata para a fabricação de álcool e a produção de amido manufaturado para as indústrias de papel e têxtil (Willard, 1993). Ainda nesse século, teve início a produção de batata "chips", cuja origem foi um "Resort" em Saratoga Springs, Nova lorque, com o Chef George Crum, em 1853 (Snack Food Association, 1987).

Após essa descoberta, durante a década de 1890, na cidade de Cleveland nos Estados Unidos da América, muitos comerciantes vendiam batatas "chips" fritas caseiramente, em grande quantidade. Hoje, os processos industriais utilizados para a fabricação de "snacks" são muito mais sofisticados, transformando flocos e grânulos de batata em "chips" lisos, enrolados, ondulados ou anelados (Willard, 1993).

Os inconvenientes do armazenamento doméstico, o descascamento e a fritura ou o cozimento vem provocando um declínio no consumo de batatas frescas em alguns países, particularmente devido à tendência mundial do aumento do consumo de alimentos prontos-para-servir, o que gera um aumento no consumo de produtos já processados. Em 1956, 23\% da produção total de batatas no mundo era industrializada e esse número aumentou para $25 \%$ em 1962 , 30\% em 1970 , chegando a $45 \%$ em 1987 (Pereira, 1987). 


\subsubsection{Características das cultivares destinadas à indústria}

As cultivares apresentam diferenças marcantes no que diz respeito ao seu potencial de uso, existindo dessa maneira, cultivares que se adaptam melhor ao consumo fresco, enquanto outras são mais adaptadas à industrialização (CoraspeLéon, 1995).

Entre as características de interesse especial para o processamento, estão o teor de açúcares redutores e a massa de material seco. Os açúcares redutores (glicose e frutose) podem reagir com os aminoácidos livres durante o processamento, desenvolvendo uma coloração escura e um sabor amargo no produto final. Por essa razão, para a indústria é desejável um baixo teor de açúcares redutores. Um teor de açúcares redutores menor que $0,1 \%$ indica que a batata é boa para fritura (Bintje, Cristal e Atlantic); entre 0,1 e $0,3 \%$ indica que a qualidade da batata é duvidosa (Piratini e Cerrito Alegre) e acima deste percentual, a batata não presta para a fritura (BR-3, Trapeira, Santo Amor, Monte Bonito, Macaca, Baronesa, Cascata). Além disso, a batata pode concentrar um teor de açúcares redutores maior em um dos lados do tubérculo, característica essa, não desejável para a indústria (Paschoalino, 1993).

Outra característica de interesse é a massa de material seco ou de sólidos totais, o que corresponde a todo material que faz parte da planta ou do tubérculo, após a remoção da água. Quanto maior a massa de material seco do tubérculo, maior o rendimento industrial. Por isso, as indústrias estabelecem um valor mínimo de massa de material seco de acordo com cada safra, abaixo do qual, elas são recusadas (Kolasa, 1993).

\subsection{Massa de material seco e acúmulo de nutrientes pela batateira}

A massa de material seco (MS) na batateira é dividida em raízes, caules, folhas e tubérculos, sendo este último órgão, o que acumula a maior parte da MS total produzida pela planta (Hooker, 1986; Westcott et al., 1991).

A produção de MS é dividida em quatro estádios fenológicos. O estádio I ou período vegetativo tem início após a quebra de dormência das gemas, quando ocorre a produção de brotos. A MS é acumulada rapidamente através do desenvolvimento rápido das raízes e da parte aérea, incluindo a emergência e indo até o início do 
"inchamento" dos tubérculos. O estádio II ou período de tuberização tem início com a formação dos tubérculos nas pontas dos estolões, mas eles ainda não estão desenvolvidos e vai até o início do enchimento dos primeiros tubérculos. Embora a formação de tubérculos continue durante o próximo estádio de desenvolvimento, os tubérculos que definirão a colheita formam-se nesse estádio. O estádio III ou período de enchimento dos tubérculos é caracterizado por uma taxa de aumento constante de massa e tamanho dos tubérculos. A parte aérea continua a crescer, porém os aumentos na massa de material seco total são, na maior parte, devido aos tubérculos. Este é o estádio mais longo e vai até a maturação. O estádio IV ou período de maturação é marcado pelo início do amarelecimento dos caules e a senescência das folhas, indo até o final do ciclo (Roberts \& Dole, 1985; Ojala, et al., 1990; Biemond \& Vos, 1992).

Na ausência de uma curva de absorção de nutrientes, a produção de MS fornece uma boa aproximação do acúmulo de nutrientes (Sousa \& Coelho, 2001) e os fatores associados àprodução de MS na cultura da batateira são: as práticas culturais, a maturidade dos tubérculos, a disponibilidade hídrica, a eficiência fotossintética e a adubação (Pereira, 1987; Beukema \& Zaag, 1990; Chapman et al., 1992; Ewing, 1997; Panique et al., 1997; Fageria et al., 1997).

Quanto à adubação, sabe-se que a disponibilidade de nitrogênio influencia a produção de MS dos tubérculos. Em países com clima temperado, os trabalhos têm mostrado aumento na produção de MS, com o aumento da dose de nitrogênio (Guasena \& Harris, 1968; Westermann \& Kleinkopf, 1985; Joern \& Vitosh, 1995; Meyer \& Marcum, 1998; Errebhi et al., 1998), porém quantidades excessivas de nitrogênio estimulam o crescimento vegetativo e atrasam a formação e a maturação dos tubérculos e, os tubérculos imaturos colhidos apresentam uma menor quantidade de MS e podem apresentar uma qualidade ruim (Kleinkopf et al., 1979; Roberts \& Dole, 1985; Harris, 1992).

Geralmente, o potássio reduz a produção de MS e, o cloreto de potássio tem produzido mais efeitos negativos quando relacionado ao sulfato, porém a aplicação adequada de nitrogênio e potássio pode aumentar a produção de MS (Saffigna \& Keeney, 1977; Roberts \& Dole, 1985).

O conhecimento da quantidade de nutrientes acumulados nas plantas, principalmente na parte colhida, é importante para se avaliar a remoção dos nutrientes 
da área de cultivo $\mathrm{e}$, tornou-se um dos componentes necessários para as recomendações econômicas de adubação. Em média, as plantas possuem cerca de $5 \%$ de nutrientes minerais no MS, porém existem grandes diferenças entre as espécies e as quantidades totais exigidas por uma cultura dependem da produtividade. Por outro lado, a absorção de nutrientes é diferente de acordo com a fase de desenvolvimento da cultura, intensificando-se no florescimento, na formação e no crescimento dos frutos ou do órgão que será colhido, por isso, além da quantidade absorvida de nutrientes, deve ser considerada também, a sua concentração nos diferentes estádios de desenvolvimento (Haag et al., 1981; Vitti et al., 1994; Malavolta et al., 1997).

De acordo com Carolus (1937), em um experimento realizado na Virginia, nos Estados Unidos da América (EUA), visando obter-se a marcha de absorção de nutrientes de uma cultivar de batata de ciclo vegetativo longo, observou que a cultura absorveu somente $9 \%$ da quantidade total dos nutrientes nas primeiras sete semanas de seu ciclo, $16 \%$ da sétima até a nona semana, $67 \%$ da décima até a décima segunda semana e, finalmente, $8 \%$ dos nutrientes restantes, entre a décima terceira e a décima quarta semana.

Hawkins (1946), trabalhando com a cultivar 'Green Mountain' no Maine (EUA), com uma população de 37.037 plantas ha ${ }^{-1}$, uma adubação com $126 \mathrm{~kg} \mathrm{ha}^{-1}$ de $\mathrm{N}(1 / 3$ nitrato de sódio $+1 / 3$ sulfato de amônio $+1 / 3$ uran), $252 \mathrm{~kg} \mathrm{ha}^{-1}$ de $\mathrm{P}_{2} \mathrm{O}_{5}$ (superfosfato simples) e $252 \mathrm{~kg} \mathrm{ha}^{-1}$ de $\mathrm{K}_{2} \mathrm{O}$ ( $1 / 2$ cloreto de potássio + 1/2 sulfato de potássio), e uma produtividade de $29 \mathrm{t} \mathrm{ha}^{-1}$, observou que o acúmulo máximo de todos os macronutrientes ocorreu cerca de 10 dias antes de se atingir produção máxima de material seco e que o acúmulo maior de MS da parte aérea ocorreu entre 61-70 dias, e para os tubérculos, entre 82-91 dias após o plantio. O acúmulo máximo de MS total ocorreu 85 dias após o plantio. Além disso, os resultados mostraram que os tubérculos acumularam as maiores quantidades de nitrogênio, fósforo e enxofre e, a parte aérea, as maiores quantidades de cálcio e magnésio. Quanto ao potássio, o acúmulo foi semelhante, para os tubérculos e a parte aérea.

Carpenter (1957), também no Maine (EUA), em um estudo sobre o acúmulo de nutrientes em plantas de batateira da cv. 'Kennebec', mostrou que o potássio foi o nutriente absorvido em maior quantidade pela planta, seguido por nitrogênio, magnésio, cálcio e fósforo. 
Jackson e Haddock (1959), em estudos realizados com a cv. 'Russet Burbank' em Utah (EUA), com uma população de 37.037 plantas ha ${ }^{-1}$, uma adubação com $90 \mathrm{~kg}$ ha-1 de $\mathrm{N}$ (sulfato de amônio), $50 \mathrm{~kg} \mathrm{ha}^{-1}$ de $\mathrm{P}_{2} \mathrm{O}_{5}$ (superfosfato triplo) e uma produtividade de $38 \mathrm{t} \mathrm{ha}^{-1}$, descobriram que o acúmulo máximo de MS ocorreu junto com os máximos de absorção de nitrogênio, fósforo e potássio, dos 88 aos 95 dias após o plantio.

Em um experimento conduzido em vasos com a cultivar 'Bintje' (ciclo de 80 dias) em Campinas, com uma população de 32.000 plantas ha ${ }^{-1}$ e uma adubação correspondente a $80 \mathrm{~kg} \mathrm{ha}^{-1}$ de $\mathrm{N}$ (sulfato de amônio), $120 \mathrm{~kg} \mathrm{ha}^{-1}$ de $\mathrm{P}_{2} \mathrm{O}_{5}$ (superfosfato simples) e $160 \mathrm{~kg} \mathrm{ha}^{-1}$ de $\mathrm{K}_{2} \mathrm{O}$ (sulfato de potássio), e uma produtividade de $15 \mathrm{t} \mathrm{ha}^{-1}$, Gargantini et al. (1963) observaram que o potássio foi o nutriente absorvido em maior quantidade pela batateira, seguido por nitrogênio, cálcio, enxofre, fósforo e magnésio. Os máximos de absorção do nitrogênio, potássio, magnésio e enxofre foram verificados entre 50 e 60 dias após o plantio, enquanto que para o fósforo e o cálcio, a absorção máxima ocorreu no final do ciclo. Ainda segundo os mesmos autores, o maior acúmulo de MS ocorreu aos 70 dias, em média 15 dias após a máxima absorção dos nutrientes.

Ezeta \& McCollum (1972), trabalhando no campo com Solanum andigena Hawkes cv. 'Renacimiento' (ciclo de 172 dias), nos Andes Peruanos, obtiveram grandes extrações de nitrogênio e potássio, para uma adubação com $160 \mathrm{~kg} \mathrm{ha}^{-1}$ de $\mathrm{N}$ (nitrato de amônio), $160 \mathrm{~kg} \mathrm{ha}^{-1}$ de $\mathrm{P}_{2} \mathrm{O}_{5}$ (superfosfato simples) e $160 \mathrm{~kg} \mathrm{ha}^{-1}$ de $\mathrm{K}_{2} \mathrm{O}$ (cloreto de potássio), com uma população de 33.333 plantas ha $^{-1}$ e uma produtividade de $41 \mathrm{t} \mathrm{ha}^{-1}$. A maior produção de MS da parte aérea ocorreu aos 137 dias e dos tubérculos, aos 172 dias após o plantio. O máximo de absorção de nitrogênio ocorreu aos 156 dias, de fósforo e potássio aos 172 dias e de cálcio e magnésio, aos 137 dias após o plantio. A absorção de nitrogênio, fósforo e potássio aumentou até o final do ciclo, do mesmo modo que a massa de material seco, porém apenas o fósforo teve comportamento semelhante àmassa de material seco durante todo o ciclo da cultura, indicando que o fósforo deve estar disponível até o final do ciclo.

Em um estudo sobre a marcha de absorção de macronutrientes por 2 cultivares de batateira ('Achat' e 'Mantiqueira' com ciclo de 100 dias), com população de 41.667 plantas ha ${ }^{-1}$ e adubação com $80 \mathrm{~kg} \mathrm{ha}^{-1}$ de $\mathrm{N}$ (sulfato de amônio), $280 \mathrm{~kg} \mathrm{ha}^{-1}$ de $\mathrm{P}_{2} \mathrm{O}_{5}$ (superfosfato simples) e $160 \mathrm{~kg} \mathrm{ha}^{-1}$ de $\mathrm{K}_{2} \mathrm{O}$ (cloreto de potássio) $+30 \mathrm{~kg} \mathrm{ha}^{-1}$ de $\mathrm{N}$, em 
Minas Gerais, Brasil, foi observado que o período de acúmulo máximo de MS ocorreu 82 dias após o plantio para ambas as cultivares e que os macronutrientes acumulados em maiores quantidades na massa de material seco total (parte aérea + tubérculo), em ordem decrescente, foram de potássio, nitrogênio, cálcio, fósforo, magnésio e enxofre. Os tubérculos acumularam as maiores quantidades de macronutrientes, com exceção do cálcio, que teve o maior acúmulo na parte aérea em ambas as cultivares (Paula et al., 1986a).

Com relação aos micronutrientes analisados, os autores observaram que o ferro, foi acumulado de modo geral, em maior quantidade pela planta inteira, seguido por manganês, zinco, boro e cobre. As folhas absorveram as maiores quantidades de ferro e manganês e os tubérculos, as maiores quantidades de boro, cobre e zinco (Paula et al., 1986b).

Feltran \& Lemos (2001), visando determinar o acúmulo de nutrientes na parte aérea e a exportação pelos tubérculos de quatro cultivares de batata ('Asterix', 'Laguna', 'Picasso' e 'Solide' aos 70 dias após a emergência, em São Manuel, Brasil, com uma adubação de plantio com $226 \mathrm{~kg} \mathrm{ha}^{-1}$ de termofosfato magnesiano em área total, 2,35 t ha ${ }^{-1}$ de 04-14-08 + 0,5\% Zn no sulco e duas adubações em cobertura com $200 \mathrm{~kg} \mathrm{ha}^{-1}$ de 20-00-20, com uma população de 35.714 plantas ha $^{-1}$, observaram que o acúmulo de nutrientes na parte aérea, de forma geral, apresentou a seguinte ordem: potássio, cálcio, nitrogênio, magnésio, fósforo, zinco e boro. Porém, as cultivares 'Laguna' e 'Solide' acumularam mais cálcio do que potássio; a cv. 'Picasso' acumulou mais nitrogênio do que potássio e as cultivares 'Asterix' e 'Laguna' acumularam mais boro do que zinco na parte aérea. Nos tubérculos, a exportação de nutrientes para todas as cultivares apresentou a seguinte ordem: potássio, nitrogênio, fósforo, magnésio, cálcio, boro e zinco.

A utilização de curvas de acúmulo de nutrientes para os diversos híbridos ou variedades cultivadas de hortaliças, como um parâmetro para a recomendação de adubação, é uma boa indicação da necessidade de nutrientes em cada etapa do desenvolvimento da planta, indicando as quantidades de nutrientes absorvidas para se atingir uma certa massa de material seco, auxiliando assim no estabelecimento de um programa de fertilização do solo para a cultura (Roberts \& Dole, 1985; Villas Bôas et al., 2001). 
Nas nossas condições, a batateira é uma planta que se desenvolve rapidamente, havendo assim, uma grande exigência de nutrientes num curto espaço de tempo. A resposta da batateira em termos de produtividade, porém, é afetada por outros fatores além da adubação, existindo também uma grande variabilidade de resposta quanto ao acúmulo de nutrientes, dependendo da cultivar. As informações em relação à marcha de absorção são escassas ou antigas, ressaltando a necessidade deste tipo de trabalho, dada a importância da cultivar 'Atlantic' em condições brasileiras. 


\section{MATERIAL E MÉTODOS}

\section{1 Áreas experimentais}

\subsubsection{Localização e características gerais das áreas experimentais}

Este trabalho foi conduzido em duas propriedades pertencentes ao Sr. Kameo Oi, ambas no município de Itapetininga, Estado de São Paulo, localizado na latitude

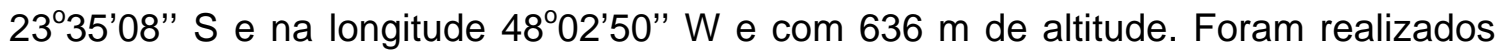
dois experimentos, um na safra das águas (Set-Dez/2001 - Fazenda Marconi) e outro na safra da seca (Fev-Mai/2002 - Área do Abacateiro). Os dados climáticos da região durante o período de cultivo da batateira encontram-se na Tabela 1.

Tabela1. Valores médios das temperaturas máxima, mínima e da precipitação pluvial mensal durante os períodos de cultivo da batateira em Itapetininga/SP.

\begin{tabular}{cccc}
\hline $\begin{array}{c}\text { Período } \\
\text { (meses) }\end{array}$ & máxima $\left({ }^{\circ} \mathrm{C}\right)$ & mínima $\left({ }^{\circ} \mathrm{C}\right)$ & $\begin{array}{c}\text { Precipitação } \\
\text { pluvial mensal }(\mathrm{mm})\end{array}$ \\
\hline Setembro / 2001 & 24,53 & 14,98 & 52,7 \\
Outubro / 2001 & 26,50 & 16,82 & 164,9 \\
Novembro / 2001 & 28,42 & 18,78 & 150,9 \\
Dezembro / 2001 & 26,94 & 23,79 & 230,9 \\
Fevereiro / 2002 & 27,51 & 20,11 & 143,9 \\
Março / 2002 & 29,91 & 21,30 & 72,6 \\
Abril / 2002 & 28,83 & 19,64 & 43,6 \\
Maio / 2002 & 24,15 & 16,51 & 122 \\
\hline
\end{tabular}

Fonte: CATI, 2001; CATI, 2002. (Comunicação pessoal). 


\subsubsection{Características dos solos}

Os solos das áreas experimentais foram classificados como LATOSSOLO VERMELHO ESCURO e a caracterização química e granulométrica dos solos (Tabelas 2 a 4) foram feitas através da análise de amostras compostas coletadas logo após a calagem. As análises foram realizadas no Laboratório de Solos do Departamento de Solos e Nutrição de Plantas da ESALQ/USP.

Tabela 2. Resultados das análises granulométricas do solo nos experimentos, proveniente da camada de 0,0 a 0,2 m em uma área não cultivada.

\begin{tabular}{|c|c|c|c|c|}
\hline \multirow[t]{2}{*}{ Área } & Areia & Silte & Argila & \multirow[t]{2}{*}{ Classe textural } \\
\hline & -----.- & $\mathrm{g} \mathrm{kg}^{-1}$ & & \\
\hline Marconi & 60 & 80 & 860 & Muito argilosa \\
\hline Abacateiro & 150 & 120 & 730 & Muito argilosa \\
\hline
\end{tabular}

Tabela 3. Resultados das análises químicas do solo nos experimentos, proveniente da camada de 0,0 a 0,2 m em uma área não cultivada.

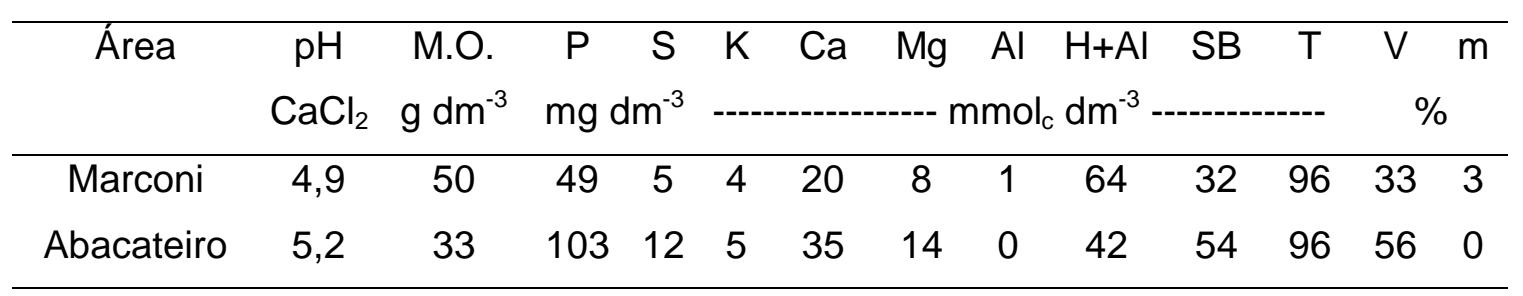

Tabela 4. Resultados das análises de micronutrientes do solo nos experimentos da Fazenda Marconi, proveniente da camada de 0,0 a 0,2 m em uma área não cultivada.

\begin{tabular}{cccccc}
\hline Área & B & $\mathrm{Cu}$ & $\mathrm{Fe}$ & $\mathrm{Mn}$ & $\mathrm{Zn}$ \\
& & & & \\
& & & & \\
Marconi & 0,6 & 0,2 & 32 & 1,4 & 0,2 \\
Abacateiro & 0,92 & 0,4 & 79 & 7,8 & 1,1 \\
\hline
\end{tabular}



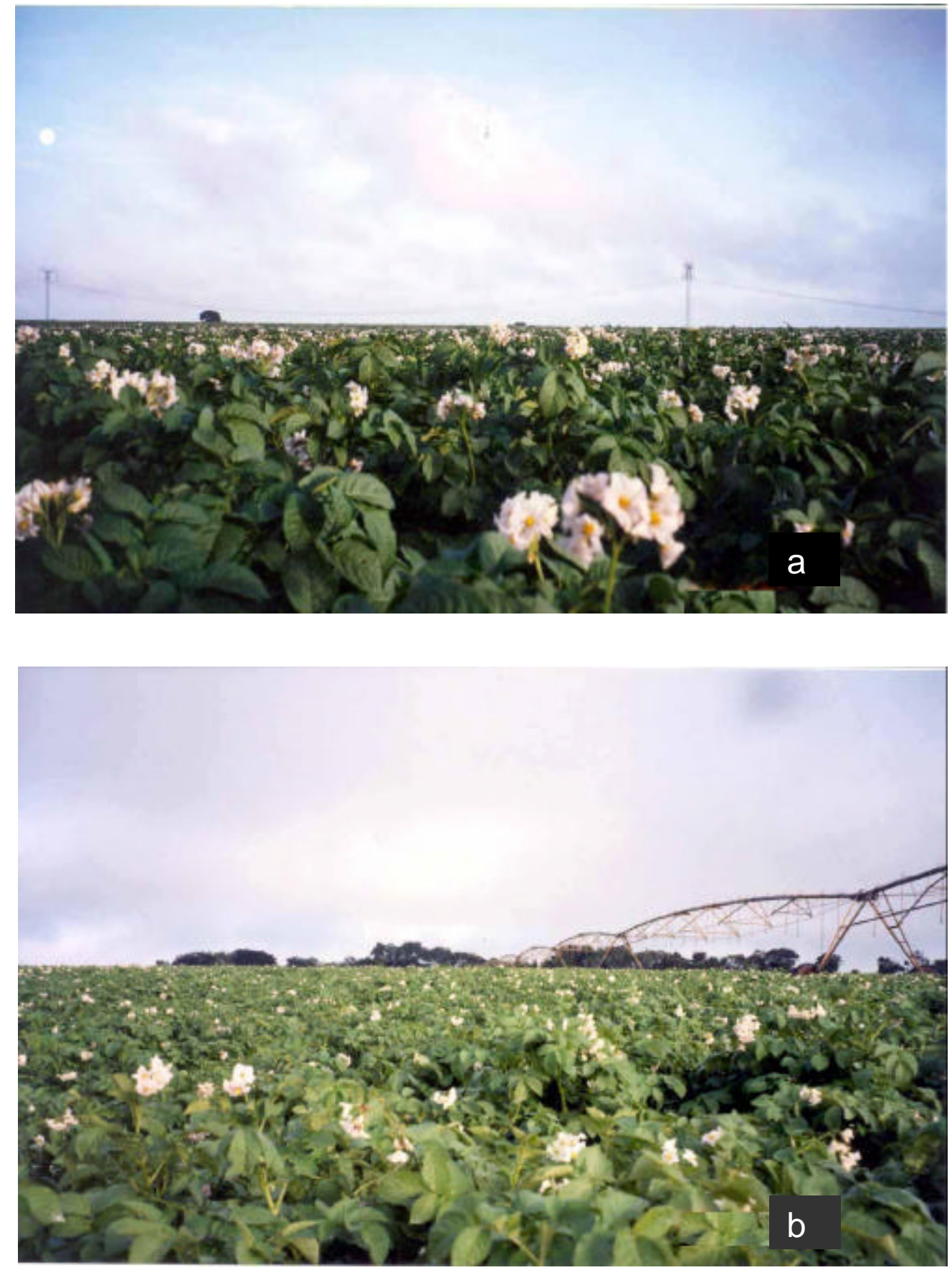

Figura 1 - Área dos experimentos. Fazenda Marconi (a) e área do Abacateiro (b). 


\subsection{Calagem, preparo do solo e adubação de plantio}

A calagem na área 1 foi feita 60 dias antes do plantio, mediante a incorporação de uma dose de 4,5 t ha ${ }^{-1}$ de calcário dolomítico (PRNT 70\%) e na área 2, 120 dias antes do plantio, com a incorporação de $2 \mathrm{t} \mathrm{ha}^{-1}$ do mesmo tipo de calcário.

O solo foi preparado de forma convencional, com uma aração, uma subsolagem e duas gradagens cerca de 30 dias antes do plantio. Em seguida foi realizada a adubação.

A adubação no sulco de plantio, feita pelo produtor, foi de $160,8 \mathrm{~kg} \mathrm{ha}^{-1}$ de $\mathrm{N}$ (sulfato de amônio), 643,2 kg ha- ${ }^{-1}$ de $\mathrm{P}_{2} \mathrm{O}_{5}$ (superfosfato simples + fosfato monoamônico ou fosfato diamônico) e $321,6 \mathrm{~kg} \mathrm{ha}^{-1}$ de $\mathrm{K}_{2} \mathrm{O}(\mathrm{KCl})$.

\subsection{Plantio e espaçamento}

Tubérculos inteiros foram plantados com uma plantadeira Watanabe de quatro linhas em duas épocas, nos dias 03 e 04 de Setembro de 2001 (safra das águas na Fazenda Marconi) e dias 23 e 24 de Fevereiro de 2002 (safra da seca na área do Abacateiro).

O espaçamento utilizado foi de 0,30 m entre plantas e 0,80m entre linhas de plantio, resultando em uma população de 41.667 plantas ha-1. A escolha do espaçamento deve-se ao fato dele favorecer a realização de uma amontoa com melhor qualidade, reduzindo, dessa forma, a possibilidade de perda de tubérculos por esverdeamento ou danos causados por insetos (larva-alfinete e traça da batata) (ELMA CHIPS, 2000).

\subsection{Cultivar}

Foi usada batata-semente certificada da cultivar 'Atlantic' $(60 \mathrm{~mm})$, fornecida pelo proprietário da fazenda. A escolha da cv. 'Atlantic' deveu-se ao fato do proprietário ter firmado contrato com uma indústria de batata "chips" e esta ser uma das poucas cultivares que possui baixos teores de açúcares redutores, mesmo quando imatura e, além disso, tem um ciclo precoce e possui teores altos de sólidos solúveis, características ideais para batata com finalidade industrial. Outro aspecto atraente da 
cv. 'Atlantic' é a elevada capacidade de produção, mesmo com baixas dosagens de fertilizantes, desde que o solo possua bons níveis de fertilidade (ELMA CHIPS, 2000).

Essa cultivar apresenta as seguintes características:

- Origem genética: proveniente do cruzamento de B5141-6 (Lenape) $x$ Wauseon, produzida e selecionada pelo Ministério de Agricultura dos Estados Unidos em 1969. Maturação: 90 - 120 dias (média estação).

- Características botânicas: plantas medianamente grandes; porte ereto; hastes grossas e de cor roxa na base, formando uma pigmentação ou pequenas manchas irregulares para cima, com nós ligeiramente inchados. Folhas medianamente pubescentes, lisas, de cor verde brilhante. Folíolos terminais grandes e ovalados; ápice cuspidado; base obtusa e assimétrica. Folíolos primários grandes e ovalados; ápice cuspidado, base obtusa, principalmente assimétrica, com três pares. Folíolos secundários e terciários numerosos. Flores numerosas com cor lavanda pálido, sobre gemas fortemente pubescentes, com uma pigmentação lavanda difusa sobre um fundo verde.

- Tubérculos: ovalados a redondos, lisos; película branca, ligeiramente reticulada a muito escamada; "olhos" brancos e superficiais; polpa branca.

- Brotos: roxos.

- Características agronômicas: alto rendimento, boa aparência, grande adaptabilidade, porém não recomendada para solos arenosos e secos. A produção de tubérculos de maior tamanho e com coração-ôco pode ser evitada, com uma adubação moderada, um espaçamento mais estreito e o controle adequado da irrigação. $O$ conteúdo total em glicoalcalóides é baixo e em material seco é elevado. A densidade específica é elevada.

- Reação àdoenças: imune ao vírus do mosaico leve (PVX), alguma resistência à Streptomyces scabies, Phytophthora infestans, Pseudomonas fluorescens e Verticillium albo-atrum e resistência à raça $A$ do nematóide dourado (Globodera rotochiensis) (ELMA CHIPS, 2000).

\subsection{Controle fitossanitário e adubação de cobertura}

O controle fitossanitário foi feito através de aplicações preventivas e de controle com defensivos químicos, a cada sete dias em média ou sempre que necessário. 
As adubações de cobertura na safra das águas foram feitas através de pulverizações com $600 \mathrm{ml}$ de Crop Set (1\% Cu p/p; 1,5\% Fe p/p e 2\% Mn p/p, com $\mathrm{d}=1,06 \mathrm{~g} / \mathrm{ml}$ ), aos 35 e 50 dias após o plantio e de 2,1 $\mathrm{kg} \mathrm{ha}^{-1}$ Forth Mix H (9\% B; 1,5\% $\mathrm{Cu} ; 2,5 \% \mathrm{Fe} ; 2 \% \mathrm{Mn} ; 4 \% \mathrm{Zn} ; 1 \% \mathrm{Mo} ; 0,6 \% \mathrm{Mg}$ e 9\% S) aos 45 e 80 dias após o plantio.

Na safra da seca, foram usados os mesmos produtos, na mesma quantidade, porém, foram duas pulverizações com Crop Set, aos 42 e 57 dias após o plantio e uma aplicação de Forth Mix H, 66 dias após o plantio.

\subsection{Irrigação}

A irrigação foi realizada através de pivô central e seu controle foi feito pelo próprio produtor, em função do aspecto visual.

\subsection{Coleta de plantas}

As coletas foram realizadas semanalmente, na parte da manhã, para evitar que as plantas murchassem até chegarem ao laboratório, tendo início 20 dias após o plantio (Figura 2b). Foram definidos os estádios de desenvolvimento e o número de plantas coletadas por parcela foi sendo reduzido à medida que as plantas se desenvolviam: no estádio I foram coletadas 15 plantas, no estádio II, 10 e, nos estádios III e IV, cinco. Foram estabelecidos, para a safra das águas os estádios: I - vegetativo, da emergência até 34 dias após plantio (DAP); II - tuberização, de 35 a 48 DAP; III enchimento de tubérculos, de 49 a 90 DAP e IV - maturação, de 91 a 111 DAP. Para a safra da seca, foram estabelecidos os estádios: I - vegetativo, da emergência até 20 DAP; II - tuberização, de 21 a 34 DAP; III - enchimento de tubérculos, de 35 a 69 DAP e IV - maturação, de 70 a 90 DAP.

Foram delimitadas quatro parcelas de $100 \times 17 \mathrm{~m}$. As coletas foram realizadas seguindo dois critérios: seleção de plantas que sempre tivessem em todos os lados da planta coletada plantas competitivas, e seleção das melhores plantas sob o aspecto visual, aparentemente bem nutridas e com ausência de viroses, até quando possível. 


\subsection{Preparo das amostras}

Após as plantas serem removidas do campo, elas eram levadas ao Laboratório de Nutrição Mineral de Plantas da Escola Superior de Agricultura "Luiz de Queiroz", sendo lavadas, agitando-as por alguns segundos em 4 etapas: água de torneira + detergente, água de torneira, água desionizada $+\mathrm{HCl}\left(0,01 \mathrm{~mol} \mathrm{~L}^{-1}\right)$ e água desionizada. Após a lavagem, as plantas foram secas ao ar para remoção do excesso de água, sendo posteriormente separadas em raízes, caules, folhas e tubérculos (Figura 2a e c). Cada parte da planta foi colocada em saco de papel pardo e levado para secagem em estufa com circulação forçada de ar a $65-70^{\circ} \mathrm{C}$, até atingir peso constante. Após a secagem, a massa das amostras foi determinada em balança analítica, para a obtenção da massa de material seco, foi moída em moinho de aço inoxidável tipo Wiley, com peneira de malha 20 mesh $(1 \mathrm{~mm})$ e armazenada em saco plástico, devidamente identificado até a análise.
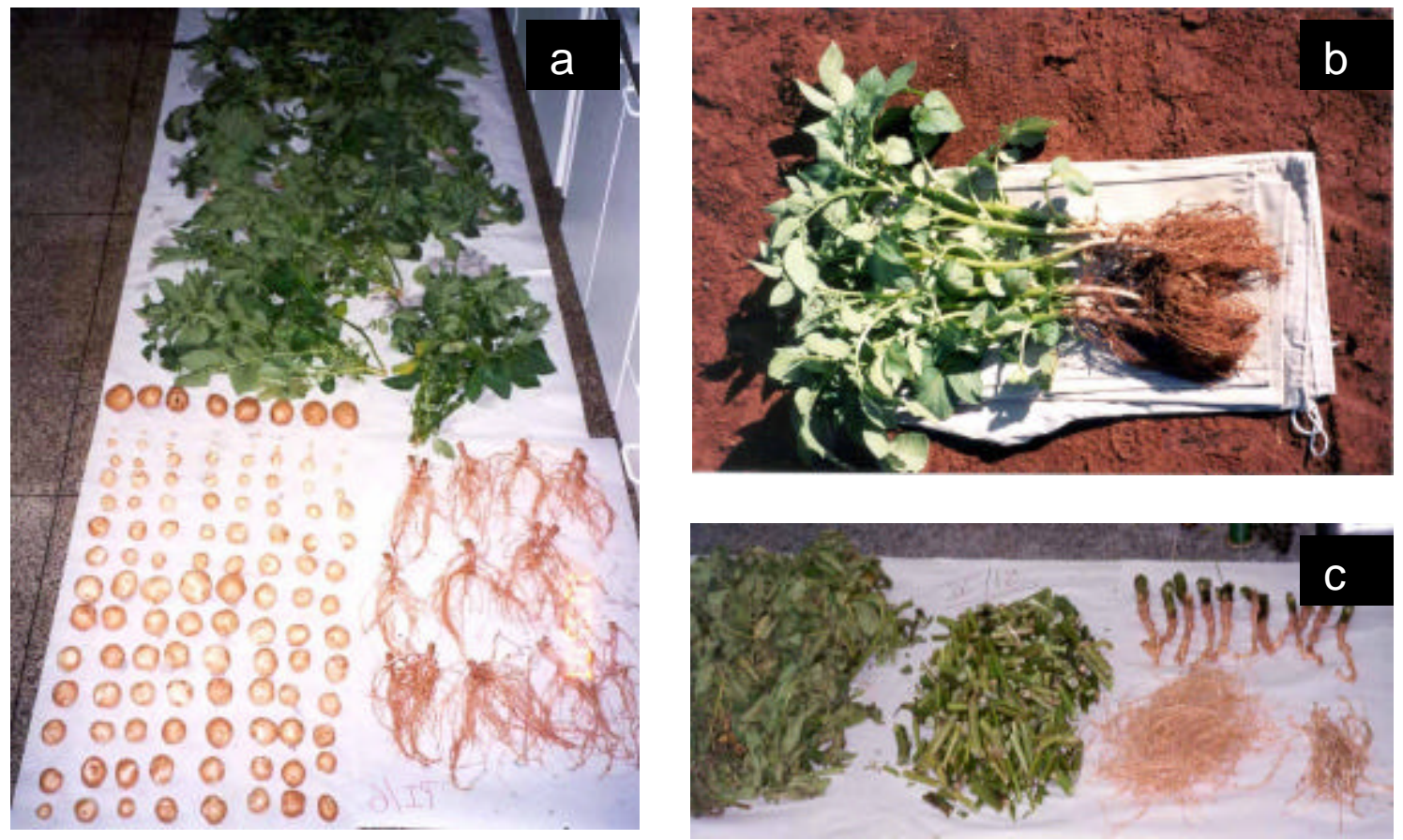

Figura 2 - Plantas de batata separadas em raízes, caules, folhas e tubérculos (a e c). Planta de batata da primeira coleta aos 20 dias após o plantio (b). 


\subsection{Análise química das plantas}

As análises químicas para a determinação dos teores de nutrientes presentes em cada órgão das plantas foram feitas nos extratos obtidos pela digestão sulfúrica (nitrogênio), nítrico-perclórica (fósforo, potássio, cálcio, magnésio, enxofre, cobre, ferro, manganês e zinco) e por via seca (boro) (Sarruge \& Haag, 1974).

O nitrogênio foi quantificado pelo método semi-micro Kjeldahl; fósforo por colorimetria do metavanadato e boro por colorimetria da azometina $\mathrm{H}$; potássio por fotometria de chama de emissão; cálcio, magnésio, cobre, ferro, manganês e zinco por espectrofotometria de absorção atômica e enxofre por turbidimetria do cloreto de bário (Sarruge \& Haag, 1974).

O resultado das análises forneceu as concentrações de nitrogênio, fósforo, potássio, cálcio, magnésio e enxofre em $\mathrm{g} \mathrm{kg}^{-1}$ e de boro, cobre, ferro, manganês e zinco em $\mathrm{mg} \mathrm{kg}^{-1}$. Para se determinar a quantidade total de nutrientes acumulados em cada parte da planta, multiplicou-se a concentração de cada nutriente pela massa de material seco do referido órgão.

\subsection{Análise estatística}

A análise estatística dos parâmetros avaliados foi feita considerando-se as duas épocas de plantio e as quatro repetições. A análise de todos os resultados do experimento foram realizados utilizando-se o programa estatístico SANEST, através da análise de variância e, quando esta era significativa, aplicou-se a análise de regressão. 


\section{RESULTADOS E DISCUSSÃO}

\subsection{Acúmulo de massa de material seco}

Para a determinação da curva de crescimento ou curva de acúmulo de massa de material seco, foram definidos os períodos dos quatro estádios de desenvolvimento da batateira, sendo considerado, para a safra das águas: I - vegetativo, da emergência até 34 dias após plantio (DAP); II - tuberização, de 35 a 48 DAP; III - enchimento de tubérculos, de 49 a 90 DAP e IV - maturação, de 91 a 111 DAP. Para a safra da seca, I - crescimento vegetativo, da emergência até 20 DAP; II - tuberização, de 21 a 34 DAP; III - enchimento de tubérculos, de 35 a 69 DAP e IV - maturação, de 70 a 90 DAP.

Os acúmulos máximos de MS total, nas safras das águas e da seca, foram significativos $(P<0,01)$ e ajustaram-se a modelos cúbicos de regressão. Na safra das águas, o acúmulo máximo de MS total foi de 219,85 $\mathrm{g}_{\text {planta- }}{ }^{-1}\left(9.160,49 \mathrm{~kg} \mathrm{ha}^{-1}\right)$ ocorreu 103 DAP e o acúmulo máximo da safra da seca foi de $149,41 \mathrm{~g}_{\text {planta }}{ }^{-1}$ $\left(6.225,46 \mathrm{~kg} \mathrm{ha}^{-1}\right)$ aos 77 DAP e foi $32 \%$ inferior ao da safra das águas. Tanto na safra das águas como na da seca, o acúmulo de MS total ocorreu no estádio de maturação (Figura 3).

Nos pontos de acúmulo máximo de MS total, a MS dos tubérculos correspondeu a aproximadamente $88 \%$ da MS total, nas duas safras. Esse resultado foi maior do que o verificado por Ezeta \& McCollum (1972), que estudando a produção de massa de material seco, absorção e exportação de nutrientes por Solanum andigena cv. 'Renacimiento' nos Andes Peruanos, observaram que $70 \%$ do total da MS produzida foi armazenada nos tubérculos, em condição de alta fertilização.

Na safra das águas, o acúmulo de MS, no final de cada estádio correspondeu a: vegetativo - 2,2 \% do total, tuberização - $13 \%$, enchimento de tubérculos - $90 \%$, e $100 \%$ na maturação. Já na seca, os valores corresponderam a 5,2; 20; 95 e 100\%, 
respectivamente.

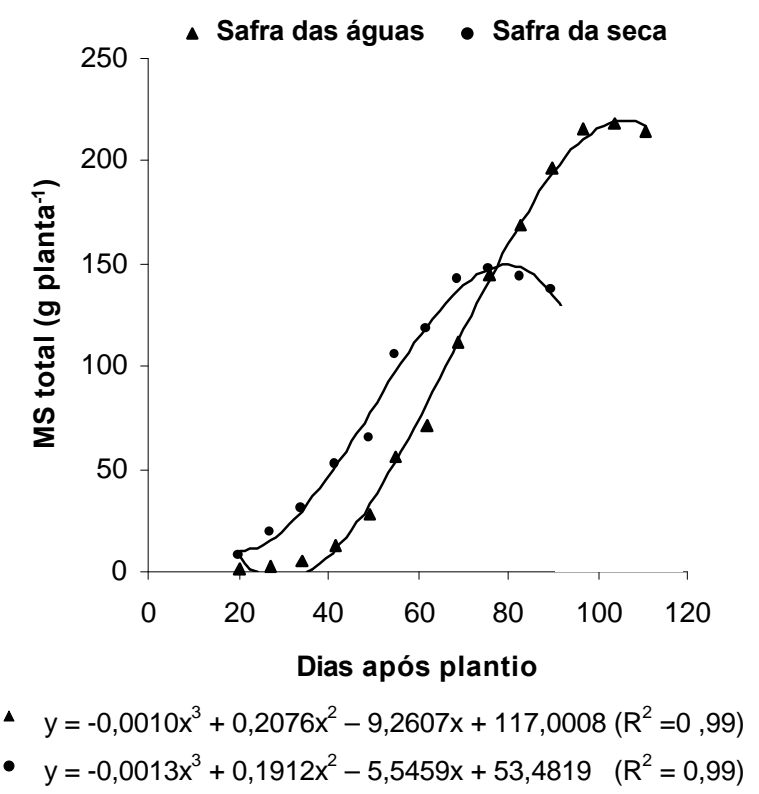

Figura 3 - Massa de material seco total nos órgãos da batateira ao longo do ciclo (g planta $\left.{ }^{-1}\right)$.

A análise de variância apresentou significância $(P<0,01)$ e ajustou-se ao modelo quadrático de regressão nas raízes, porém nos caules, nas folhas e nos tubérculos, apresentou significância $(P<0,01)$ e ajustou-se ao modelo cúbico de regressão, nas duas safras (Figura 4).

O acúmulo de MS nas raízes foi maior na safra da seca do que na das águas, (0,69 $\mathrm{g}$ planta $^{-1}$ ou $28,75 \mathrm{~kg} \mathrm{ha}^{-1}$ aos 48 DAP, na safra da seca e $0,64 \mathrm{~g} \mathrm{planta}^{-1}$ ou $26,67 \mathrm{~kg} \mathrm{ha}^{-1}$ aos 72 DAP, na safra das águas). Porém, as curvas apresentaram comportamento semelhante, com acúmulo contínuo até o máximo, que ocorreu no enchimento dos tubérculos.

O acúmulo de MS nos caules foi maior na safra da seca do que na safra das águas. O acúmulo máximo na safra da seca ocorreu aos 47 DAP e foi de $14,47 \mathrm{~g}$ planta $^{-1}\left(602,92 \mathrm{~kg} \mathrm{ha}^{-1}\right)$ e na safra das águas, aos 83 DAP e foi de $12,33 \mathrm{~g} \mathrm{planta}^{-1}$ $\left(513,75 \mathrm{~kg} \mathrm{ha}^{-1}\right)$. Ambos ocorreram no estádio do enchimento dos tubérculos.

Quanto à folhas, oc orreu acúmulo maior de MS na safra das águas. Nessa safra, observou-se um aumento contínuo até 69 DAP, seguido de um período de pequeno aumento, até os 79 DAP, quando ocorreu o acúmulo máximo de 
22,67 $\mathrm{g} \mathrm{planta}^{-1}\left(944,59 \mathrm{~kg} \mathrm{ha}{ }^{-1}\right)$. Depois de $79 \mathrm{DAP}$, ocorreu um período de decréscimo pequeno até os 95 DAP, seguido de uma queda brusca até o final do ciclo, possivelmente devido à doenças que ocorreram nesse período.

- Safra das águas - Safra da seca
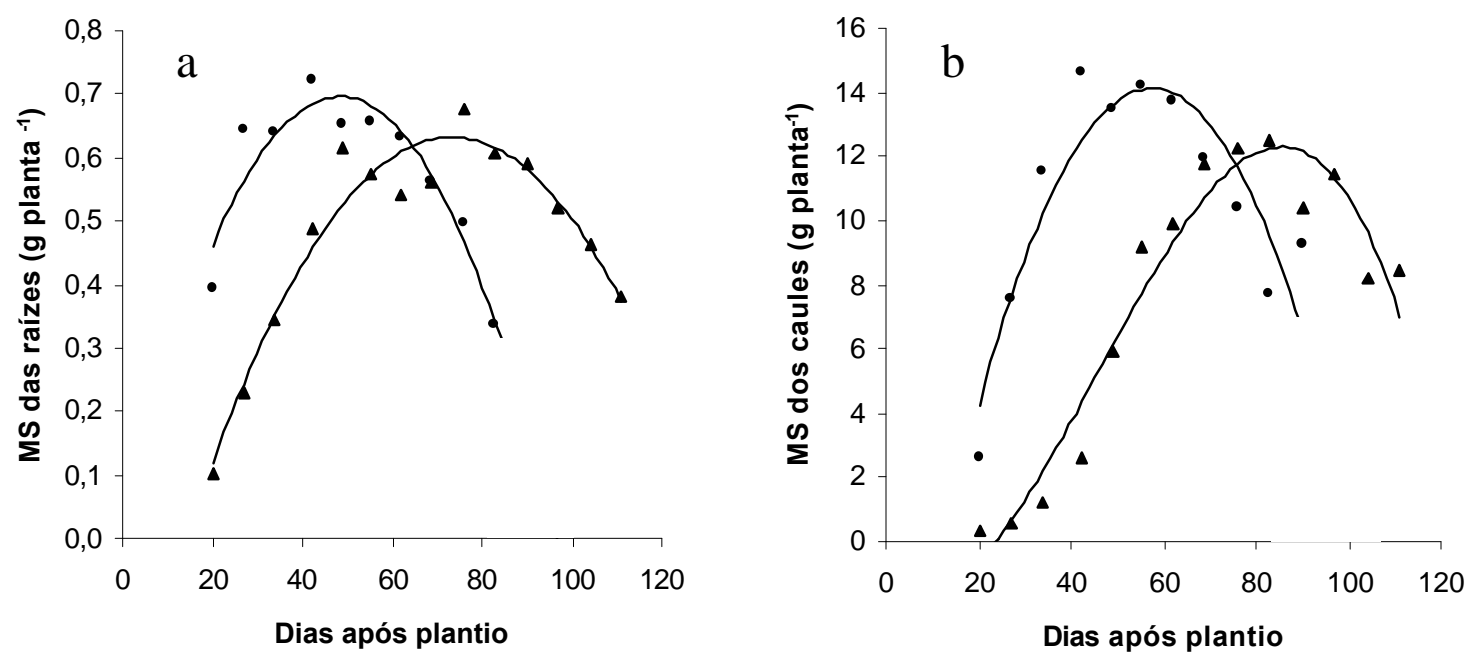

$$
\begin{array}{ll}
\Delta y=-0,0002 x^{2}+0,0273 x-0,3446 & \left(R^{2}=0,92\right) \\
\text { - } y=-0,0003 x^{2}+0,0289 x-0,0032 & \left(R^{2}=0,81\right)
\end{array}
$$

$$
\begin{array}{ll}
\text { - } y=-0,00005 x^{3}+0,0063 x^{2}+0,0203 x-3,3468 & \left(R^{2}=0,91\right) \\
\text { - } y=0,0002 x^{3}-0,0376 x^{2}+2,3144 x-30,5116 & \left(R^{2}=0,84\right)
\end{array}
$$

- Safra das águas - Safra da seca
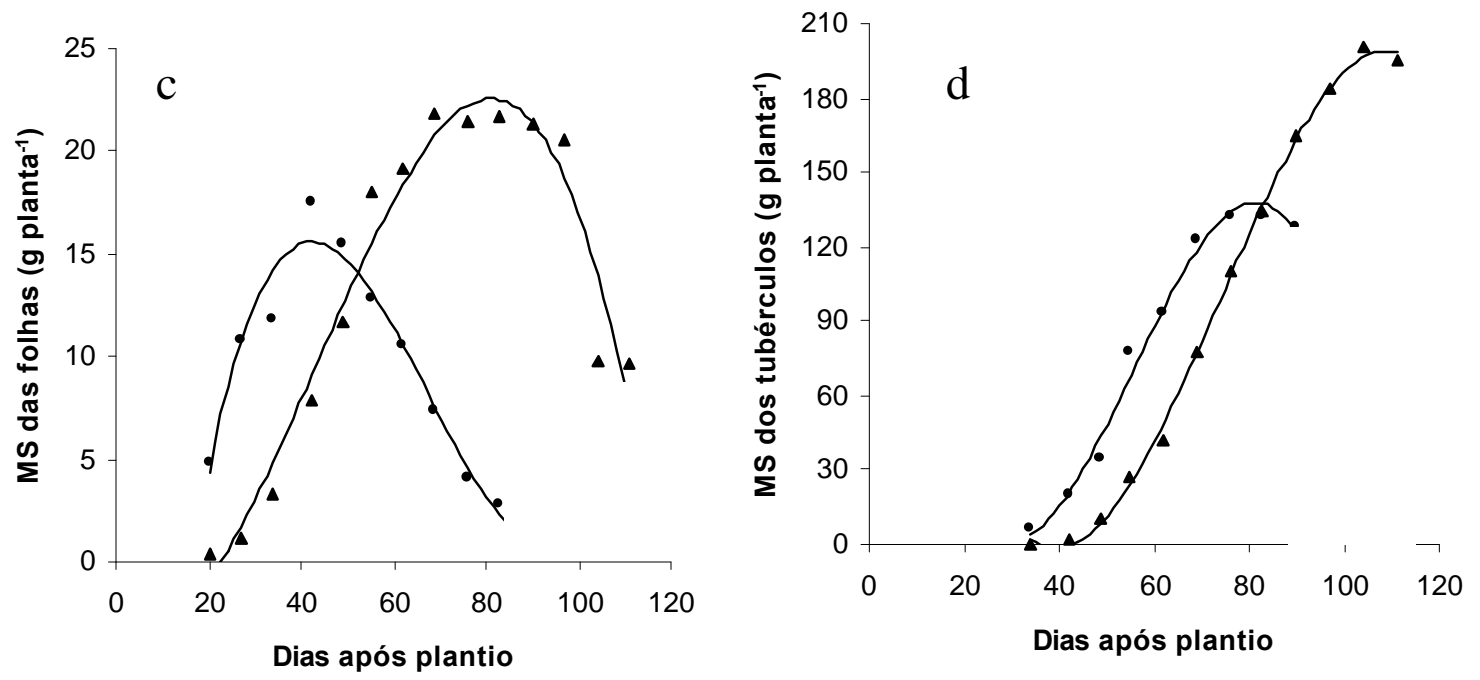

$y=-0,0001 x^{3}+0,013 x^{2}+0,0131 x-5,8461 \quad\left(R^{2}=0,96\right)$

$\Delta=-0,0012 x^{3}+0,271 x^{2}-15,0562 x+249,453\left(R^{2}=0,99\right)$

- $y=0,0003 x^{3}-0,0521 x^{2}+2,9365 x-35,665\left(R^{2}=0,95\right)$

- $y=-0,0019 x^{3}+0,322 x^{2}-13,9173 x+182,008\left(R^{2}=0,99\right)$

Figura 4 -MS acumulada nos órgãos da batateira ao longo do ciclo, nas safras das águas e da seca $\left(g\right.$ planta $\left.^{-1}\right)$ : raiz (a), caule (b), folha (c) e tubérculo (d). 
Na safra da seca, ocorreu o contrário, pois houve um aumento rápido até o acúmulo máximo de MS das folhas (15,5 $\mathrm{g} \mathrm{planta}^{-1}$ ou 645,83 $\mathrm{kg} \mathrm{ha}^{-1}$ ) aos 41 DAP, seguido de uma redução contínua até a colheita, que foi ocasionada pelo ataque descontrolado de lagartas, o que causou redução na área foliar. Esse período coincidiu com o estádio de enchimento de tubérculos e afetou a produtividade.

A manutenção das folhas no enchimento dos tubérculos é muito importante para se obter uma boa produtividade, pois é nesse estádio que os fotossintatos e os nutrientes minerais da parte aérea são translocados para os tubérculos (Roberts \& Dole, 1985).

Portanto, quanto mais tempo as folhas permanecerem sadias, maior a produtividade.

O comportamento da curva de acúmulo de MS nos tubérculos foi semelhante ao da curva de acúmulo de MS total ao longo do ciclo. Na safra das águas, a MS dos tubérculos correspondeu a $13,37 \%$ da MS total, no final do estádio I; 49,67\% no final do estádio II; $83,66 \%$ no final do estádio III; $91,38 \%$ no final do estádio IV e esses valores, na safra da seca corresponderam a $0 ; 37,15 ; 86,08$ e $93,25 \%$, respectivamente.

O acúmulo máximo de MS nos tubérculos ocorreu no estádio de maturação, diferindo das outras partes da planta. Na safra das águas, o máximo ocorreu aos 106 DAP, com acúmulo de 198,57 $\mathrm{g}_{\text {planta }}{ }^{-1}$ de $\mathrm{MS}\left(8.273,82 \mathrm{~kg} \mathrm{ha}^{-1}\right)$, que corresponde a $22,2 \%$ da massa do material fresco (MF) $\left(37.232,17 \mathrm{~kg} \mathrm{ha}^{-1}\right)$, enquanto que na safra da seca, o máximo ocorreu aos 82 DAP, com acúmulo de 137,62 $\mathrm{g} \mathrm{planta}^{-1}$ de MS $\left(5.734,21 \mathrm{~kg} \mathrm{ha}^{-1}\right)$, que corresponde a $22 \%$ da MF $\left(25.803,94 \mathrm{~kg} \mathrm{ha}^{-1}\right)$.

\subsubsection{Taxa de acúmulo de massa de material seco}

A taxa maior de acúmulo na safra das águas foi de 5,9 $\mathrm{g} \mathrm{planta}^{-1} \mathrm{dia}^{-1}$ (246 kg ha-1 $\mathrm{dia}^{-1}$ ) no período de 62 a 69 DAP e, na safra da seca, a taxa de acúmulo foi semelhante, de 5,8 $\mathrm{g}_{\text {planta }}{ }^{-1} \mathrm{dia}^{-1}\left(242 \mathrm{~kg} \mathrm{ha}^{-1} \mathrm{dia}^{-1}\right)$, porém ocorreu no período de 48 a 55 DAP, pois as condições ambientais foram diferentes, apesar de ser a mesma cultivar.

Hawkins (1946), em estudo sobre a taxa de absorção e translocação de nutrientes minerais pelas batatas em Aroostook County, no Maine (EUA), encontrou que a maior taxa de acúmulo do MS total foi de $133 \mathrm{~kg} \mathrm{ha}^{-1} \mathrm{dia}^{-1}$ entre 61 e 70 DAP na 
cv. 'Green Mountain', taxa essa menor do que as observadas neste experimento, pois trata-se de cultivares e condições edafo-climáticas bem diferentes. Já Ezeta \& McCollum (1972), com a cv. 'Renacimiento', observaram que a taxa de acúmulo máximo do MS total foi maior, de $198 \mathrm{~kg} \mathrm{ha}^{-1} \mathrm{dia}^{-1}$ e ocorreu no intervalo de três semanas, de 137 a 156 DAP, com nível elevado de fertilização. Taxas de crescimento de 47 e $205 \mathrm{~kg} \mathrm{ha}^{-1}$ dia $^{-1}$ foram encontradas no mesmo intervalo, para fertilização baixa e média, respectivamente.

A taxa maior de crescimento do MS dos tubérculos ocorreu dos 63 aos 69 DAP, e foi de $218 \mathrm{~kg} \mathrm{ha}^{-1} \mathrm{dia}^{-1}$ de MS, que corresponde a cerca de $980 \mathrm{~kg} \mathrm{ha}^{-1} \mathrm{dia}^{-1}$ de MF. Já na safra da seca, a taxa maior de crescimento da parte aérea ocorreu entre 20 e 27 DAP, e para os tubérculos, entre 49 e 55 DAP, com acréscimos de $254 \mathrm{~kg} \mathrm{ha}^{-1} \mathrm{dia}^{-1} \mathrm{de}$ MS, nesse período, que equivale a cerca de $1.145 \mathrm{~kg} \mathrm{ha}^{-1} \mathrm{dia}^{-1}$ da massa de material fresco, porém o ciclo da safra da seca foi reduzido, e um dos fatores que pode ter contribuído para isso foi a temperatura (máxima e mínima), que nos meses iniciais, foi maior em relação àda safra das águas (ao contrário do que se esperava, pois com temperaturas mais amenas e a diminuição do fotoperíodo, as fases inicias são mais prolongadas e o translocamento dos fotossintatos é mais lento, levando a uma produtividade maior). Essas temperaturas elevadas favoreceram o ataque das lagartas, que promoveu redução na área foliar, causando estresse na planta e como mecanismo de defesa, os fotossintatos foram translocados rapidamente para os tubérculos.

Hawkins (1946) encontrou uma taxa máxima de acúmulo de MS nos tubérculos, de $158 \mathrm{~kg} \mathrm{ha-1} \mathrm{dia}^{-1}$ para a cv. 'Green Mountain', Jackson \& Haddock (1959), $172 \mathrm{~kg} \mathrm{ha}^{-1} \mathrm{dia}^{-1}$ de MS para os tubérculos da cv. 'Russet Burbank' e Paula et al. (1986a), 71,9 kg ha ${ }^{-1} \mathrm{dia}^{-1}$ para a cv. 'Mantiqueira' e 29,4 $\mathrm{kg} \mathrm{ha}^{-1} \mathrm{dia}^{-1}$ para a cv. 'Achat'.

As taxas negativas de acúmulo da parte aérea durante os períodos de 84 a 90 e também após os 97 DAP na safra das águas e a partir dos 41 DAP na safra da seca podem ser explicados pelo translocamento de fotossintatos e minerais da parte aérea para os tubérculos (Roberts \& Dole, 1985).

Outro aspecto importante é a relação existente entre a parte aérea (caule + folhas) e a subterrânea (raízes + tubérculos). Do plantio até a floração, a MS da parte aérea foi maior, se comparada àparte subterrânea e a partir desse ponto, ocorreu uma inversão nos valores, tanto na safra das águas quanto na seca. 


\subsection{Acúmulo e exportação de macronutrientes}

\subsubsection{Nitrogênio}

O acúmulo total de nitrogênio na cultura (raízes + caules + folhas + tubérculos) nas duas safras, ajustou-se ao modelo quadrático de regressão $(P<0,01)$ (Figura 5).

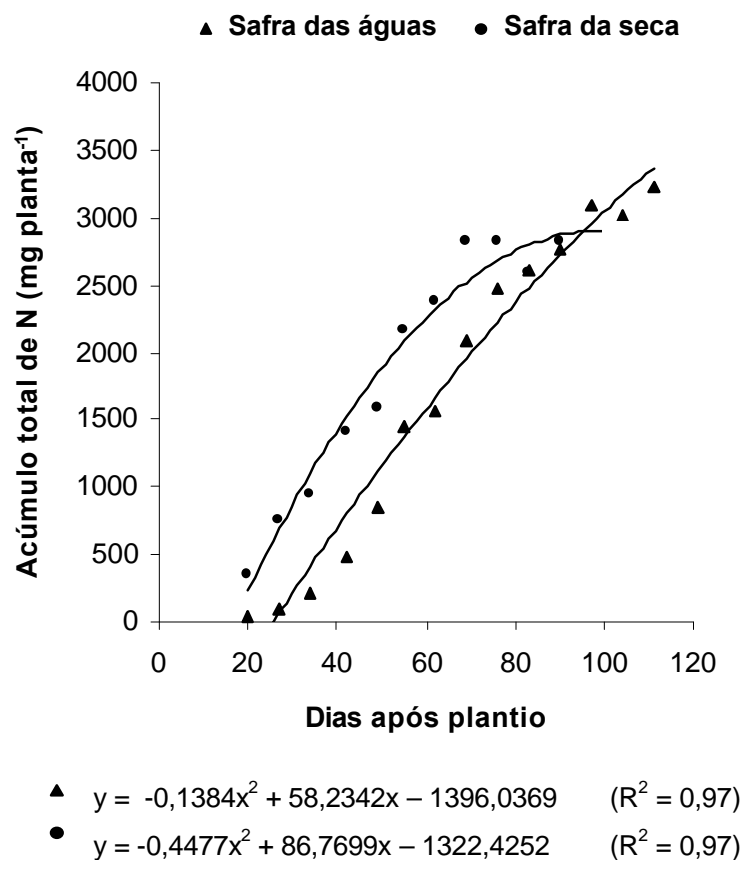

Figura 5 - Nitrogênio total acumulado na batateira ao longo do ciclo nas safras das águas e da seca (mg planta $\left.{ }^{-1}\right)$.

O acúmulo total máximo corresponde ànecessidade total do nutriente para a cultura e, varia em função da produtividade e da cultivar. Dessa forma, como no presente experimento, apenas uma cultivar, porém duas safras (produtividades diferentes), pode-se observar que o acúmulo máximo de nitrogênio total na safra das águas foi de $3.362,14 \mathrm{mg} \mathrm{planta}^{-1}\left(140 \mathrm{~kg} \mathrm{ha}^{-1}\right)$, para uma produtividade de $36,5 \mathrm{t} \mathrm{ha}^{-1} \mathrm{e}$ exportação de $120 \mathrm{~kg} \mathrm{ha}^{-1}$, enquanto que na safra da seca, esse acúmulo foi menor, de 2.860,71 mg planta ${ }^{-1}\left(119 \mathrm{~kg} \mathrm{ha}^{-1}\right)$ para $24 \mathrm{t} \mathrm{ha}^{-1}$ e exportação de $113 \mathrm{~kg} \mathrm{ha}^{-1}$. Observase também, que nas águas, a exportação corresponde a $86 \%$ da necessidade, valor considerado baixo, quando comparado com os $95 \%$ da safra da seca.

Valores diferentes de acúmulo máximo e exportação de nitrogênio foram observados por diversos autores: Hawkins (1946) - acúmulo de $160 \mathrm{~kg} \mathrm{ha}^{-1}$ de 
nitrogênio na cv. 'Green Mountain' para $29 \mathrm{t} \mathrm{ha}^{-1}$ e exportação de $106 \mathrm{~kg} \mathrm{ha}^{-1}$; Jackson \& Haddock (1959) - acúmulo de $155 \mathrm{~kg} \mathrm{ha}^{-1} \mathrm{na} \mathrm{cv}$. 'Russet Burbank' para $38 \mathrm{t} \mathrm{ha-1} \mathrm{e}$ exportação de $110 \mathrm{~kg} \mathrm{ha}^{-1}$; Gargantini et al. (1963) - acúmulo de $56 \mathrm{~kg} \mathrm{ha}^{-1} \mathrm{na} \mathrm{cv}$. 'Bintje' para 15 t ha' ${ }^{-1}$ e exportação de $32 \mathrm{~kg} \mathrm{ha}^{-1}$; Ezeta e McCollum (1972) - acúmulo de $141 \mathrm{~kg} \mathrm{ha}^{-1}$ de nitrogênio na cv. 'Renacimiento' para $41 \mathrm{t} \mathrm{ha}^{-1}$ e exportação de $77 \mathrm{~kg} \mathrm{ha}^{-1}$; Paula et al. (1986a) - 53 kg ha ${ }^{-1}$ para cv. 'Mantiqueira' e exportação de 42,6 kg ha-1 e Paula et al. (1986a) - $31 \mathrm{~kg} \mathrm{ha}^{-1}$ para a cv. 'Achat' e exportação de $27,13 \mathrm{~kg} \mathrm{ha}^{-1}$.

Fontes (1997), relatou que uma tonelada de tubérculos retira do solo de 3,0 a $5,0 \mathrm{~kg}$ de nitrogênio. Esses valores foram confirmados neste experimento, ressaltando que na safra das águas, a remoção foi menor $\left(3,29 \mathrm{~kg} \mathrm{t}^{-1}\right)$ e na safra da seca $\left(4,71 \mathrm{~kg} \mathrm{t}^{-1}\right)$. Feltran \& Lemos (2001) também encontraram valores próximos aos do presente experimento, para as cultivares 'Asterix' $\left(3,246 \mathrm{~kg} \mathrm{t}^{-1}\right)$, 'Laguna' $\left(3,244 \mathrm{~kg} \mathrm{t}^{-1}\right)$, e 'Solide' (3,548 $\left.\mathrm{kg} \mathrm{t}^{-1}\right)$. Somente a cv. 'Picasso' (2,608 $\left.\mathrm{kg} \mathrm{t}^{-1}\right)$ apresentou um valor menor em relação \&̀ demais.

Na safra das águas, a taxa maior de acúmulo de nitrogênio total foi de $85,4 \mathrm{mg}$ planta ${ }^{-1} \mathrm{dia}^{-1}\left(3,5 \mathrm{~kg} \mathrm{ha}^{-1} \mathrm{dia}^{-1}\right)$ e na seca, de 82,43 mg planta ${ }^{-1} \mathrm{dia}^{-1}\left(3,4 \mathrm{~kg} \mathrm{ha}^{-1} \mathrm{dia}^{-1}\right)$, sendo esses valores observados no enchimento dos tubérculos (49 a 55 DAP). Valores menores foram observados por Ezeta \& McCollum (1972), com taxa de 2,5 kg ha-1 $\mathrm{dia}^{-1}$ para a cv. 'Renacimiento' e Paula et al. (1986a), nas cultivares 'Mantiqueira', com $1,14 \mathrm{~kg} \mathrm{ha}^{-1} \mathrm{dia}^{-1}$ e 'Achat' com 0,3 kg ha-1 $\mathrm{dia}^{-1}$. Já Hawkins (1946), observou valor maior de taxa de acúmulo de nitrogênio em relação ao desse experimento, com a cv. 'Green Mountain' (4,2 kg ha $\left.{ }^{-1} \mathrm{dia}^{-1}\right)$.

Paula et al. (1986a), em um estudo sobre a produção de massa de material seco e absorção de macronutrientes por cultivares de batata, observou que da quantidade total máxima acumulada de nitrogênio, a maior parte estava nos tubérculos ( $88 \%$ do $\mathrm{N}$ total nos tubérculos de 'Achat' e $80 \%$ em 'Mantiqueira').

Segundo Ojala et al. (1990), a batateira requer uma quantidade baixa de nitrogênio durante o crescimento vegetativo. Aproximadamente $15 \%$ do nitrogênio total, para a cv. 'Russet Burbank', ocorreu nesse período e sua deficiência pode ser corrigida rapidamente nessa fase, com uma adubação de cobertura seguida de irrigação.

Ezeta \& McCollum (1972) relataram que para a maioria das cultivares de batata, a quantidade de nitrogênio acumulado no início da tuberização foi menor que 
$50 \%$ do total. Segundo Westermann \& Kleinkopf (1985), na fase inicial do enchimento dos tubérculos, a batateira requer uma grande quantidade de nitrogênio. Aproximadamente $58 \%$ do nitrogênio total absorvido pela parte aérea ocorreu no início do enchimento de tubérculos, e $71 \%$ na metade desse mesmo estádio. No presente experimento, $20 \%$ de todo o nitrogênio extraído pela cultura foi absorvido na tuberização e $60 \%$ no enchimento de tubérculos, na safra das águas. Já na safra da seca, esses valores corresponderam a 24 e $76 \%$, respectivamente, confirmando os relatos dos autores citados. O acúmulo de nitrogênio nas raízes, caules e folhas foi significativo $(P<0,01)$ e ajustou-se ao modelo quadrático de regressão e, ao modelo linear de regressão, para os tubérculos (Figura 6).

$\mathrm{Na}$ safra da seca ocorreu um ataque de lagartas nas folhas, no estádio de enchimento de tubérculos, o que provocou uma redução considerável na área foliar e, com a redução da área foliar, o acúmulo de nitrogênio nas folhas e nos tubérculos foi menor nessa safra.

Na safra das águas, o acúmulo máximo de nitrogênio nas raízes, caules, folhas e tubérculos ocorreu aos 63, 74, 71 e 111 DAP e foi de 12,47, 180,58, 789,48 e 2.933,54 mg planta ${ }^{-1}\left(0,52 ; 7,5 ; 32,89\right.$ e 122,2 $\left.\mathrm{kg} \mathrm{ha}^{-1}\right)$, respectivamente, e esses valores corresponderam, na seca, a 16,64; 287,25; 573,04 e 2.736,24 mg planta $^{-1}$ $\left(0,69 ; 11,97 ; 23,88\right.$ e $\left.114,01 \mathrm{~kg} \mathrm{ha}^{-1}\right)$ aos 43; 52; 43 e 90 DAP. Resultados diferentes foram observados por Paula et al. (1986a), com as cultivares 'Achat' $(0,26 ; 0,47 ; 2,91$ e $\left.27,13 \mathrm{~kg} \mathrm{ha}^{-1}\right)$ e 'Mantiqueira' $\left(0,57 ; 1,47 ; 8,71\right.$ e $\left.42,60 \mathrm{~kg} \mathrm{ha}^{-1}\right)$.

A taxa maior de acúmulo de nitrogênio nas raízes, na safra das águas, ocorreu na fase vegetativa, de 20 a 27 DAP; nos caules, na tuberização, de 42 a 48 DAP e nas folhas, no enchimento de tubérculos, de 49 a 55, respectivamente. Na safra da seca, a taxa maior de acúmulo de nitrogênio nas raízes, caules e folhas ocorreu de 20 a 27 DAP na tuberização.

Nos tubérculos, a taxa maior de acúmulo de nitrogênio na safra das águas foi de $81,87 \mathrm{mg} \mathrm{planta}^{-1} \mathrm{dia}^{-1}\left(3,41 \mathrm{~kg} \mathrm{ha}^{-1} \mathrm{dia}^{-1}\right)$ e ocorreu no período de 63 a 69 DAP e na seca, o valor correspondente foi $105,12 \mathrm{mg} \mathrm{planta}^{-1} \mathrm{dia}^{-1}\left(4,38 \mathrm{~kg} \mathrm{ha}^{-1} \mathrm{dia}^{-1}\right)$ no período de 49 a 55 DAP. Já Hawkins (1946), com a cv 'Green Mountain' observou uma taxa de acúmulo de 2,67 kg ha ${ }^{-1} \mathrm{dia}^{-1}$, de 92 a 101 DAP, Jackson \& Haddock (1959) taxa de 2,2 $\mathrm{kg} \mathrm{ha}^{-1} \mathrm{dia}^{-1}$, de 88 a 95 DAP na cv. 'Russet Burbank' e Ezeta \& McCollum(1972), com taxa de acúmulo de $1,8 \mathrm{~kg} \mathrm{ha}^{-1} \mathrm{dia}^{-1}$ de nitrogênio nos tubérculos da cv. 
‘Renacimiento no período de 137 a 172 DAP.
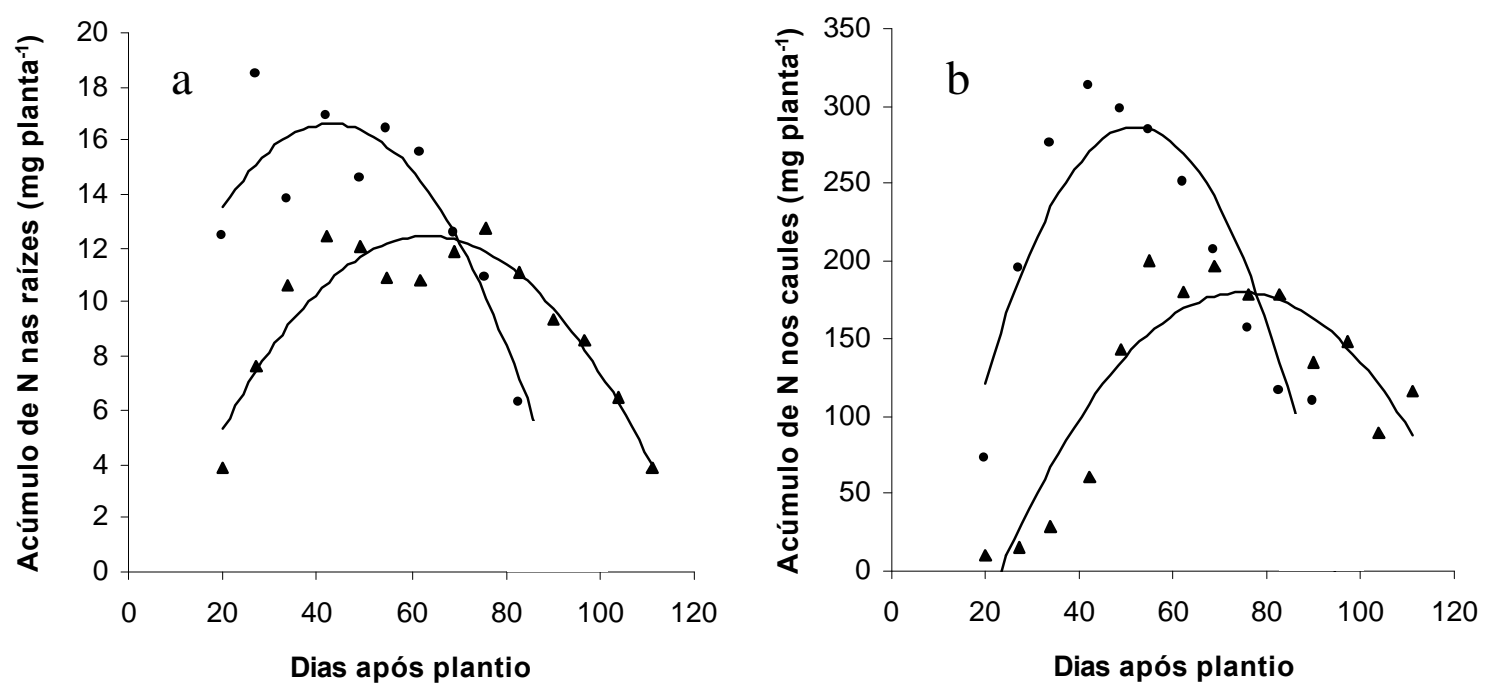

\y=-0,00378 $x^{2}+0,4793 x-2,7298 \quad\left(R^{2}=0,88\right)$

Dias após plantio

- $y=-0,00596 x^{2}+0,5134 x-5,5847 \quad\left(R^{2}=0,78\right)$

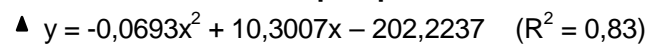

- $y=-0,1603 x^{2}+16,6593 x-145,5839 \quad\left(R^{2}=0,82\right)$

\section{\ Safra das águas}

- Safra da seca
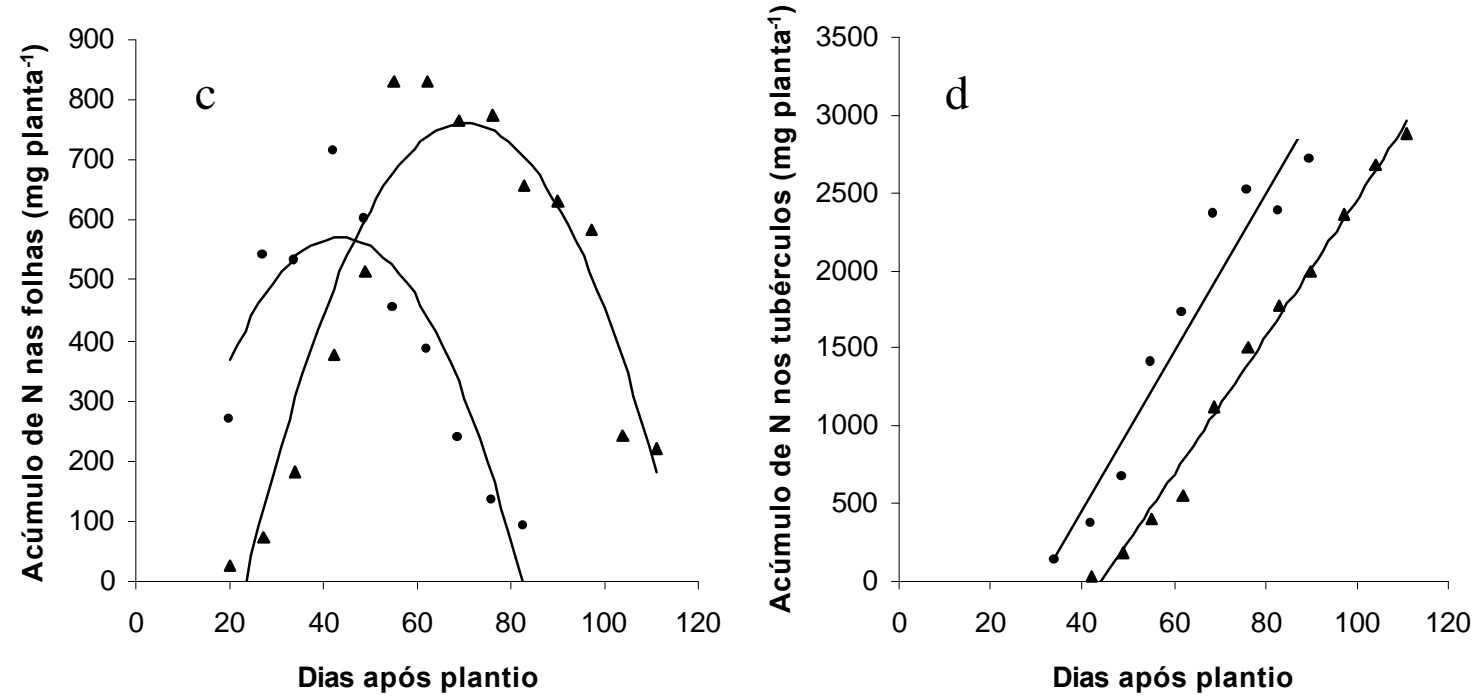

$\begin{array}{ll}\Delta y=-0,3994 x^{2}+56,6524 x-1219,3922 & \left(R^{2}=0,92\right) \\ \text { - } y=-0,3747 x^{2}+32,5028 x-131,7734 & \left(R^{2}=0,83\right)\end{array}$
\ $y=46,6177 x-1908,0198$
$\left(R^{2}=0,99\right)$
- $y=-0,5374 x^{2}+116,7488 x-3418,5038 \quad\left(R^{2}=0,96\right)$

Figura 6 - Nitrogênio acumulado nos órgãos da batateira ao longo do ciclo ( $\left.\mathrm{mg} \mathrm{planta}^{-1}\right)$ : raízes (a), caules (b), folhas (c) e tubérculos (d). 


\subsubsection{Fósforo}

O acúmulo total de fósforo na safra das águas apresentou significância $(P<0,01)$, ajustando-se ao modelo quadrático de regressão, nas duas safras (Figura 7$)$.

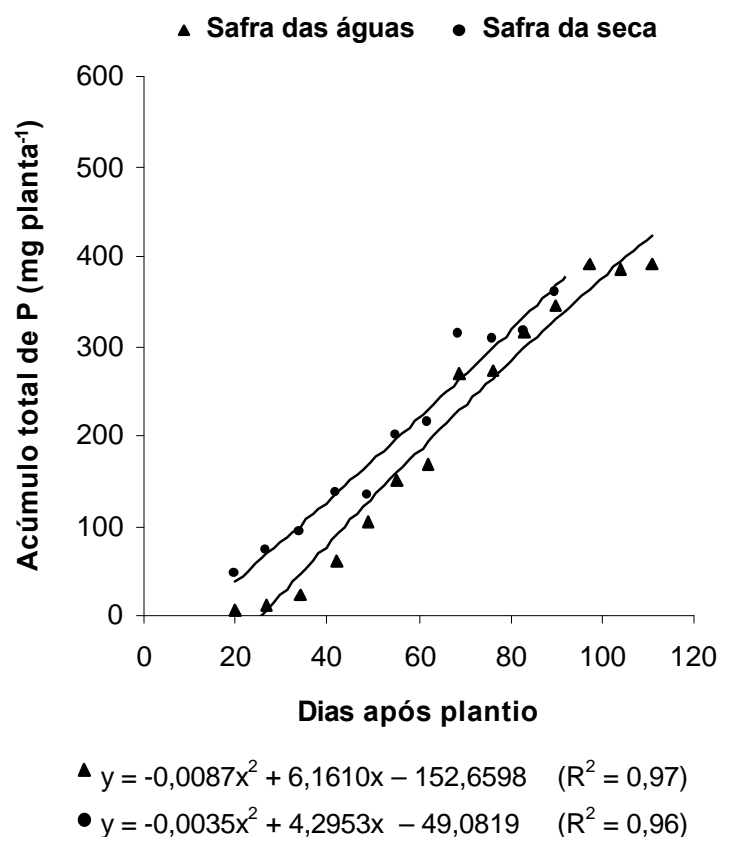

Figura 7 - Fósforo total acumulado na batateira ao longo do ciclo, nas safras das águas e da seca (mg planta ${ }^{-1}$ ).

Na safra das águas, o acúmulo máximo de fósforo total foi de $422,91 \mathrm{mg} \mathrm{planta}^{-1}$ $\left(17,62 \mathrm{~kg} \mathrm{ha}^{-1}\right)$ aos 111 DAP, para $36,5 \mathrm{t} \mathrm{ha}^{-1}$ e uma exportação de $15 \mathrm{~kg} \mathrm{ha}^{-1}$, na seca, de $366,33 \mathrm{mg}$ planta $^{-1}\left(15,26 \mathrm{~kg} \mathrm{ha}^{-1}\right)$ aos 90 DAP para $24 \mathrm{t} \mathrm{ha}^{-1}$ e uma exportação de $14,7 \mathrm{~kg} \mathrm{ha}^{-1}$, sendo que o acúmulo máximo ocorreu na maturação nas duas safras. Hawkins (1946) observou, com a cv. 'Green Mountain', um acúmulo máximo de fósforo total menor do que o observado neste experimento (12,7 $\left.\mathrm{kg} \mathrm{ha}^{-1}\right)$ para uma produtividade de $29 \mathrm{t} \mathrm{ha}^{-1}$ e exportação de $9,8 \mathrm{~kg} \mathrm{ha}^{-1}$, que foi semelhante ao valor obtido por Jackson \& Haddock (1959), com a cv. 'Russet Burbank' (13 kg ha-1), para $38 \mathrm{t} \mathrm{ha}^{-1}$ e uma exportação de $11 \mathrm{~kg} \mathrm{ha}^{-1}$. Gargantini et al. (1963), com a cv. 'Bintje', verificou um valor ainda menor de acúmulo máximo de fósforo total ( $\left.11 \mathrm{~kg} \mathrm{ha}^{-1}\right)$, para $15 \mathrm{t} \mathrm{ha}^{-1}$ e uma exportação de $10 \mathrm{~kg} \mathrm{ha}^{-1}$, porém Ezeta \& McCollum (1972) observaram um acúmulo maior ( $19 \mathrm{~kg} \mathrm{ha}^{-1}$ ), para uma produtividade de $41 \mathrm{t} \mathrm{ha}^{-1}$ e uma exportação 
de 14 kg ha ${ }^{-1}$ na cv. 'Renacimiento' e Paula et al. (1986a), 4,7 kg ha-1 para cv. 'Mantiqueira' e uma exportação de 4,5 kg ha-1 e Paula et al. (1986a), 3,2 kg ha-1 para a cv. 'Achat' e uma exportação de 3,06 kg ha-1.

Fontes (1997) relatou que uma tonelada de tubérculos retira do solo de 0,3 a $0,5 \mathrm{~kg}$ de fósforo. Um valor maior foi encontrado neste experimento na safra da seca $\left(0,61 \mathrm{~kg} \mathrm{t}^{-1}\right)$, porém o valor encontrado na safra das águas $\left(0,42 \mathrm{~kg} \mathrm{t}^{-1}\right)$ confirmou 0 relato do autor. Feltran \& Lemos (2001) encontraram valores próximos em relação aos do presente experimento, nas cultivares 'Asterix' (0,633 $\left.\mathrm{kg} \mathrm{t}^{-1}\right)$, 'Laguna' $\left(0,623 \mathrm{~kg} \mathrm{t}^{-1}\right)$, 'Picasso' (0,543 kg t'-1) e 'Solide' $\left(0,649 \mathrm{~kg} \mathrm{t}^{-1}\right)$.

As taxas maiores de acúmulo de fósforo total nas duas safras tiveram o mesmo valor, de 14,5 mg planta ${ }^{-1} \mathrm{dia}^{-1}\left(0,60 \mathrm{~kg} \mathrm{ha}^{-1} \mathrm{dia}^{-1}\right)$ e ocorreram no enchimento de tubérculos, dos 63 aos 69 DAP. Valores menores de taxa de acúmulo foram observados por Hawkins (1946) na cv. 'Green Mountain' $\left(0,28 \mathrm{~kg} \mathrm{ha}^{-1} \mathrm{dia}^{-1}\right)$, Ezeta \& McCollum (1972) na cv. 'Renacimiento' $\left(0,22 \mathrm{~kg} \mathrm{ha}^{-1} \mathrm{dia}^{-1}\right)$ e Paula et al. (1986a), nas cv. 'Mantiqueira' $\left(0,11 \mathrm{~kg} \mathrm{ha}^{-1} \mathrm{dia}^{-1}\right)$ e 'Achat' $\left(0,04 \mathrm{~kg} \mathrm{ha}^{-1} \mathrm{dia}^{-1}\right)$.

Ezeta \& McCollum (1972), estudando produção de massa de material seco, absorção de nutrientes e remoção pela batateira, observaram que as curvas de fósforo e de produção de massa de material seco estavam intimamente relacionadas, indicando que a suplementação deve ser contínua. Tal fato foi reafirmado por Fontes (1997), que constatou que o fósforo é absorvido continuamente pela cultura, assim como o cálcio.

O acúmulo de fósforo, nas raízes, caules e folhas apresentou significância $(P<0,01)$ e ajustou-se ao modelo quadrático de regressão, enquanto para os tubérculos, a significância $(P<0,01)$ foi observada, porém foi ajustada ao modelo linear de regressão para as duas safras (Figura 8).

Na safra das águas, o acúmulo máximo de fósforo nas raízes, caules e folhas ocorreu aos 61, 68 e 69 DAP e foi de 1,36, 23,23 e 55,4 mg planta $^{-1}(0,66,0,97$ e 2,31 $\left.\mathrm{kg} \mathrm{ha}^{-1}\right)$, respectivamente e, esses valores corresponderam na seca, a 1,56, 22,04 e 46,51 mg planta ${ }^{-1}(0,07,0,92$ e 1,94 kg ha-1) aos 26, 39 e 35 DAP. Paula et al.(1986a) encontrou valores menores que os encontrados neste trabalho, para todos esses órgãos estudados.

Nas duas safras, o acúmulo máximo de fósforo nas raízes, caules e folhas ocorreu no estádio de enchimento de tubérculos, a única exceção foram as raízes da 
safra da seca, que ocorreu na tuberização.

\Safra das águas - Safra da seca
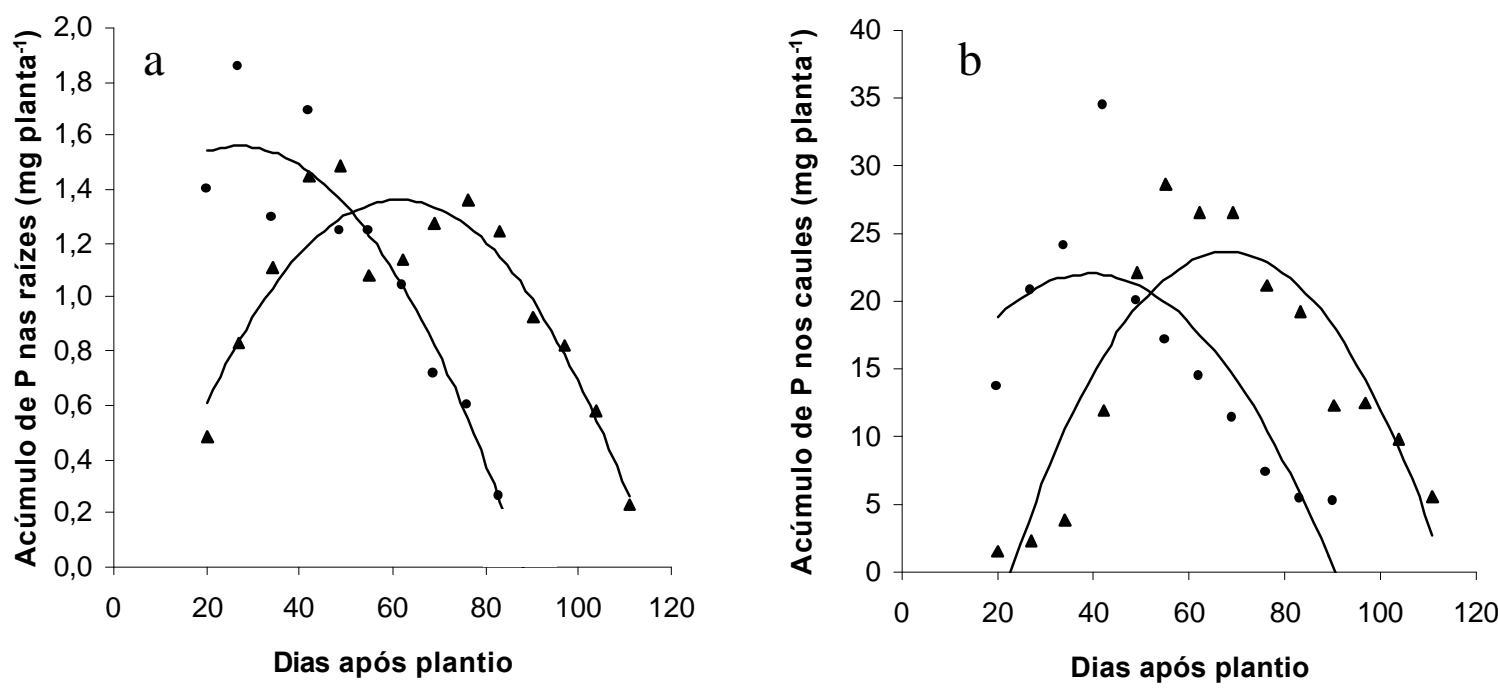

\ $y=-0,0004 x^{2}+0,0540 x-0,2873 \quad\left(R^{2}=0,85\right)$

\ $y=-0,0111 x^{2}+1,5161 x-28,3171 \quad\left(R^{2}=0,82\right)$

- $y=-0,0004 x^{2}+0,0219 x-1,2662 \quad\left(R^{2}=0,89\right)$

- $y=-0,0083 x^{2}+0,6492 x-9,4031 \quad\left(R^{2}=0,89\right)$

\section{\Safra das águas - Safra da seca}

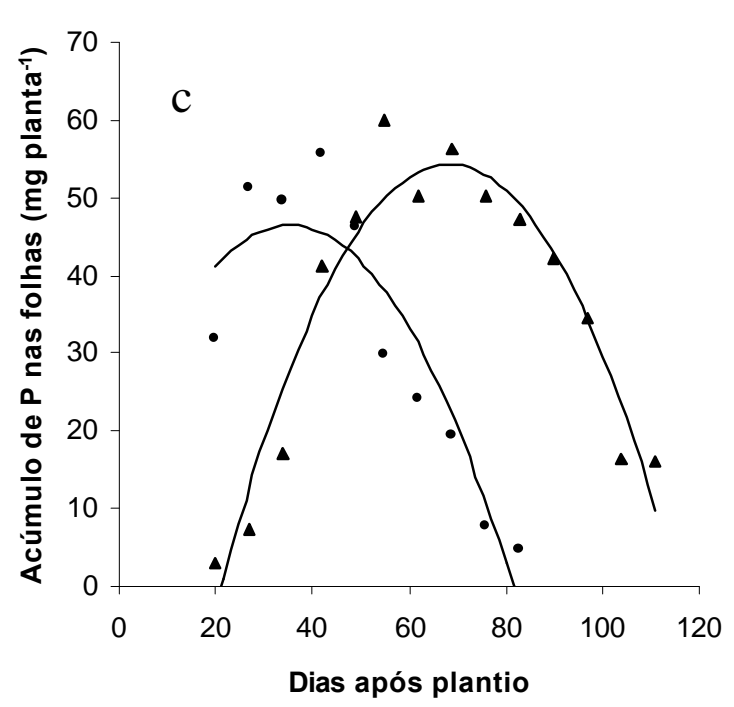

\ $y=-0,0263 x^{2}+3,6140 x-68,8159 \quad\left(R^{2}=0,91\right)$

- $y=-0,02156 x^{2}+1,5188 x+19,7571 \quad\left(R^{2}=0,86\right)$

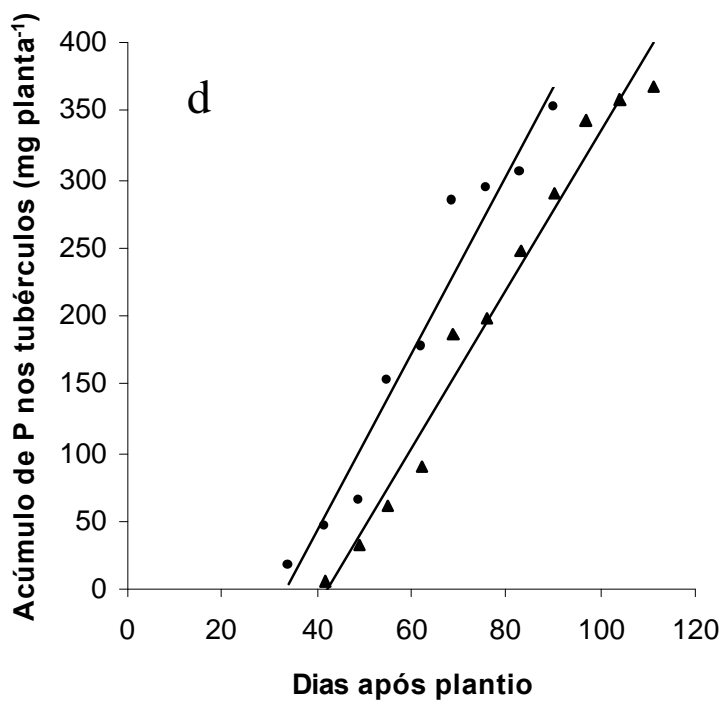

\ $y=5,7374 x-237,8752 \quad\left(R^{2}=0,98\right)$

- $y=6,4578 x-213,1929 \quad\left(R^{2}=0,96\right)$

Figura 8 - Fósforo acumulado nos órgãos da batateira ao longo do ciclo (mg planta ${ }^{-1}$ ): raízes (a), caules (b), folhas (c) e tubérculos (d). 
Quanto aos tubérculos, o acúmulo máximo de fósforo foi de 398,97 $\mathrm{mg} \mathrm{planta}^{-1}$ $\left(16,62 \mathrm{~kg} \mathrm{ha}^{-1}\right)$ aos 111 DAP nas águas e de 368,01 mg planta-1 (15,33 kg ha $\left.\mathrm{mas}^{-1}\right)$ ao DAP na seca e ambos ocorreram na maturação. Resultados diferentes foram observados por Paula et al. (1986a) nas cultivares 'Achat' e 'Mantiqueira' (3,06 e 4,15 $\mathrm{kg} \mathrm{ha}^{-1}$, respectivamente).

Na safra das águas, a taxa maior de acúmulo de fósforo nas raízes ocorreu no crescimento vegetativo de 20 a 27 DAP e nos caules e folhas, na tuberização de 42 a 48 e 35 a 41 DAP, respectivamente e nos tubérculos, no enchimento de tubérculos de 63 a 69 DAP.

Já na safra da seca, a taxa maior de acúmulo de fósforo nas raízes ocorreu no crescimento vegetativo, da emergência até 20 DAP, nas folhas, no início da tuberização, de 20 a 27 DAP, nos caules no início do enchimento de tubérculos de 35 a 41 DAP e nos tubérculos, no final da mesma fase, de 63 a 69 DAP.

\subsubsection{Potássio}

O acúmulo total de potássio apresentou significância $(P<0,01)$, ajustando-se ao modelo quadrático de regressão, nas duas safras (Figura 9).

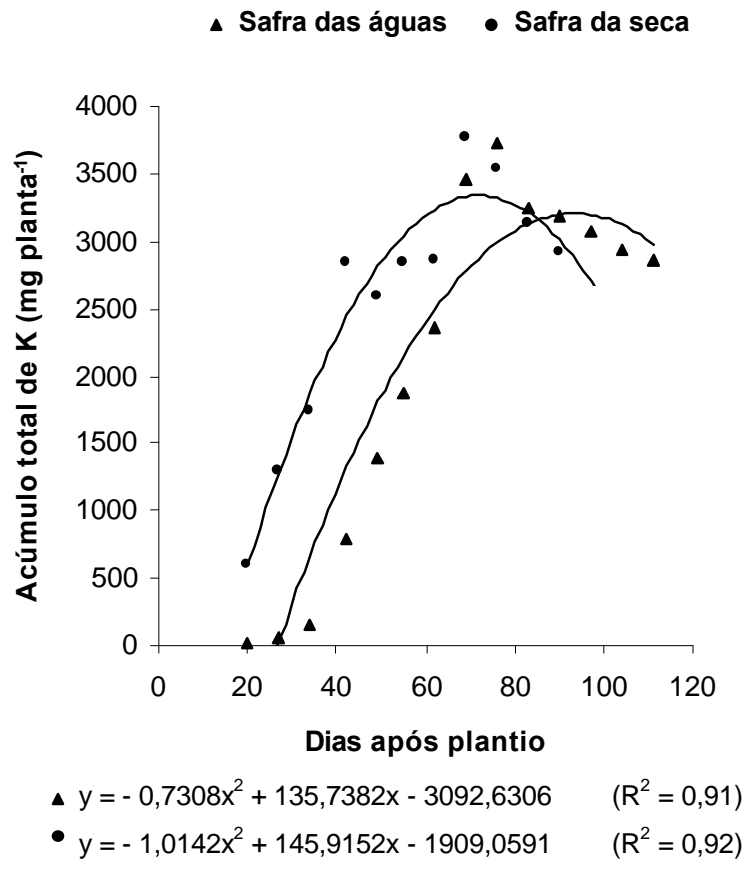

Figura 9 - Potássio total acumulado pela batateira ao longo do ciclo, nas safras das águas e da seca (mg planta ${ }^{-1}$ ). 
Na safra das águas, o acúmulo máximo de potássio total foi de $3.210,5 \mathrm{mg}$ planta $^{-1}\left(133,8 \mathrm{~kg} \mathrm{ha}^{-1}\right)$ aos 93 DAP, para uma produtividade de $36,5 \mathrm{t} \mathrm{ha}^{-1}$ e uma exportação de $104 \mathrm{~kg} \mathrm{ha}^{-1}$. Na seca, o acúmulo máximo foi de 3.339,4 $\mathrm{mg}$ planta $^{-1}$ $\left(139,1 \mathrm{~kg} \mathrm{ha}^{-1}\right)$ aos 72 DAP com uma exportação de $119 \mathrm{~kg} \mathrm{ha}^{-1}$. Nas duas safras, este acúmulo máximo ocorreu no início da maturação. Pode-se observar que, apesar da produtividade na safra da seca ser menor que a da safra das águas, o acúmulo máximo de potássio total e a exportação foram maiores na seca. Isso indica que a remoção de potássio por tonelada de tubérculos na seca $(4,96)$ foi maior do que nas águas $(2,88)$.

Hawkins (1946), com a cv. 'Green Mountain', observou valor maior de acúmulo máximo de potássio total $\left(215 \mathrm{~kg} \mathrm{ha}^{-1}\right)$, apesar da produtividade (29 $\left.\mathrm{t} \mathrm{ha}^{-1}\right)$ ser menor que a da safra das águas e a exportação foi de $109 \mathrm{~kg} \mathrm{ha}^{-1}$. Jackson \& Haddock (1959), com a cv. 'Russet Burbank', observaram valor de $151 \mathrm{~kg} \mathrm{ha}^{-1}$, para uma produtividade de $38 \mathrm{t} \mathrm{ha}^{-1}$ e uma exportação de $112 \mathrm{~kg} \mathrm{ha}^{-1}$ e Ezeta \& McCollum (1972), com a cv. 'Renacimiento' também observaram valor maior de acúmulo máximo de potássio total (403 $\mathrm{kg} \mathrm{ha}^{-1}$ ) que a cv. 'Atlantic' deste experimento, porém a produtividade também foi maior $\left(41 \mathrm{t} \mathrm{ha}^{-1}\right)$. Isso mostra a diferença de capacidade de acúmulo de potássio entre as cultivares.

Fontes (1999) relatou que de uma maneira geral, uma tonelada de tubérculos remove do solo $3,75 \mathrm{~kg}$ de potássio. Pode-se observar um valor maior de retirada de potássio que o desse autor, pois no presente experimento na safra da seca $\left(4,96 \mathrm{~kg} \mathrm{t}^{-1}\right)$ e um valor menor na safra das águas $\left(2,88 \mathrm{~kg} \mathrm{t}^{-1}\right)$. Feltran \& Lemos (2001) observaram valores semelhantes ao relatado por Fontes, nas cultivares 'Asterix' $\left(3,660 \mathrm{~kg} \mathrm{t}^{-1}\right)$, 'Laguna' (3,688 kg t $\left.{ }^{-1}\right)$, 'Picasso' (3,511 $\left.\mathrm{kg} \mathrm{t}^{-1}\right)$ e 'Solide' $\left(3,702 \mathrm{~kg} \mathrm{t}^{-1}\right)$.

O acúmulo de potássio nas raízes, caules, folhas e tubérculos, nas duas safras, apresentou significância $(\mathrm{P}<0,01)$ e ajustou-se ao modelo quadrático de regressão, com a única exceção para os tubérculos na safra da seca, que apresentou significância $(P<0,01)$ e ajustou-se ao modelo linear (Figura 10).

Na safra das águas, a taxa maior de acúmulo de potássio foi de $6,5 \mathrm{~kg} \mathrm{ha}^{-1} \mathrm{dia}^{-1}$ e ocorreu entre 63 e 69 DAP, período este, que coincidiu com a maior taxa de acúmulo de fósforo, porém, o valor observado para potássio foi dez vezes maior do que aquele observado para fósforo nesse mesmo período. Ezeta \& McCollum (1972) observaram 
uma proporção semelhante com a cv. 'Russet Burbank' de 6,6 $\mathrm{kg} \mathrm{ha}^{-1} \mathrm{dia}^{-1}$ entre $95 \mathrm{e}$ 116 DAP.

Na safra das águas, o acúmulo máximo de potássio nas raízes, caules, folhas e tubérculos ocorreu aos 68, 72, 70 e 111 DAP e foi de 9,47, 546,36, 1.058,93 e $2.458,61 \mathrm{mg}$ planta $^{-1}\left(0,39,22,77,44,12\right.$ e 102,44 kg ha $\left.{ }^{-1}\right)$, respectivamente, e esses valores corresponderam na seca, a 17,32, 805,59, 1.103,32 e 3.202,36 mg planta-1 $\left(0,72,33,57,45,97\right.$ e 133,43 $\left.\mathrm{kg} \mathrm{ha}^{-1}\right)$ e ocorreram aos 32, 52, 46 e 90 DAP.

Valores bem menores de acúmulo máximo de potássio nos órgãos foram encontrados por Paula et al. (1986a), com exceção das raízes na safra das águas, com as cultivares 'Achat' $\left(0,54,2,10,5,23\right.$ e 36,30 e kg ha $\left.{ }^{-1}\right)$ e 'Mantiqueira' $(0,61,5,63,9,51$ e $60 \mathrm{~kg} \mathrm{ha}^{-1}$ ).

Na safra das águas, a maior taxa de acúmulo de potássio nas raízes, caules e folhas ocorreu na tuberização, de 35 a 48 DAP e nos tubérculos, na maturação, dos 98 aos 104 DAP.

Já na safra da seca, a maior taxa de acúmulo de potássio nos caules, ocorreu na tuberização, de 28 a 34 DAP, nas folhas ocorreu no início do enchimento de tubérculos, nas raízes na metade e, nos tubérculos, no final da mesma fase ( 35 a 41, 49 a 55 e 63 a 69 DAP, respectivamente).

Hawkins (1946) , em estudo com a cv. 'Green Mountain', relatou que a taxa de acúmulo de potássio foi consideravelmente maior quando comparado àde outros nutrientes e ressaltou que a taxa de acúmulo de potássio total aumentou de $0,56 \mathrm{~kg} \mathrm{ha}$ ${ }^{1} \mathrm{dia}^{-1}$ aos 40 DAP, para aproximadamente $3,36 \mathrm{~kg} \mathrm{ha}^{-1} \mathrm{dia}^{-1}$ aos 50 DAP e 6,72 kg ha ${ }^{-1}$ dia $^{-1}$ aos 53 DAP. O mesmo autor afirmou ainda, que a taxa maior de acúmulo de potássio total ocorreu de 61 a 70 DAP e foi de $7,1 \mathrm{~kg} \mathrm{ha}^{-1} \mathrm{dia}^{-1} \mathrm{de}_{2} \mathrm{O}$ e nos tubérculos, de 82 a 91 DAP, e foi de $3,5 \mathrm{~kg} \mathrm{ha}^{-1} \mathrm{dia}^{-1}$ de $\mathrm{K}_{2} \mathrm{O}$.

Taxas menores de acúmulo de potássio nos tubérculos foram observadas por Jackson \& Haddock (1959), com a cv. 'Russet Burbank' (2,65 kg ha ${ }^{-1}$ dia $^{-1}$ de $\mathrm{K}_{2} \mathrm{O}$ ), no período de 88 a 95 DAP. 
¿ Safra das águas - Safra da seca
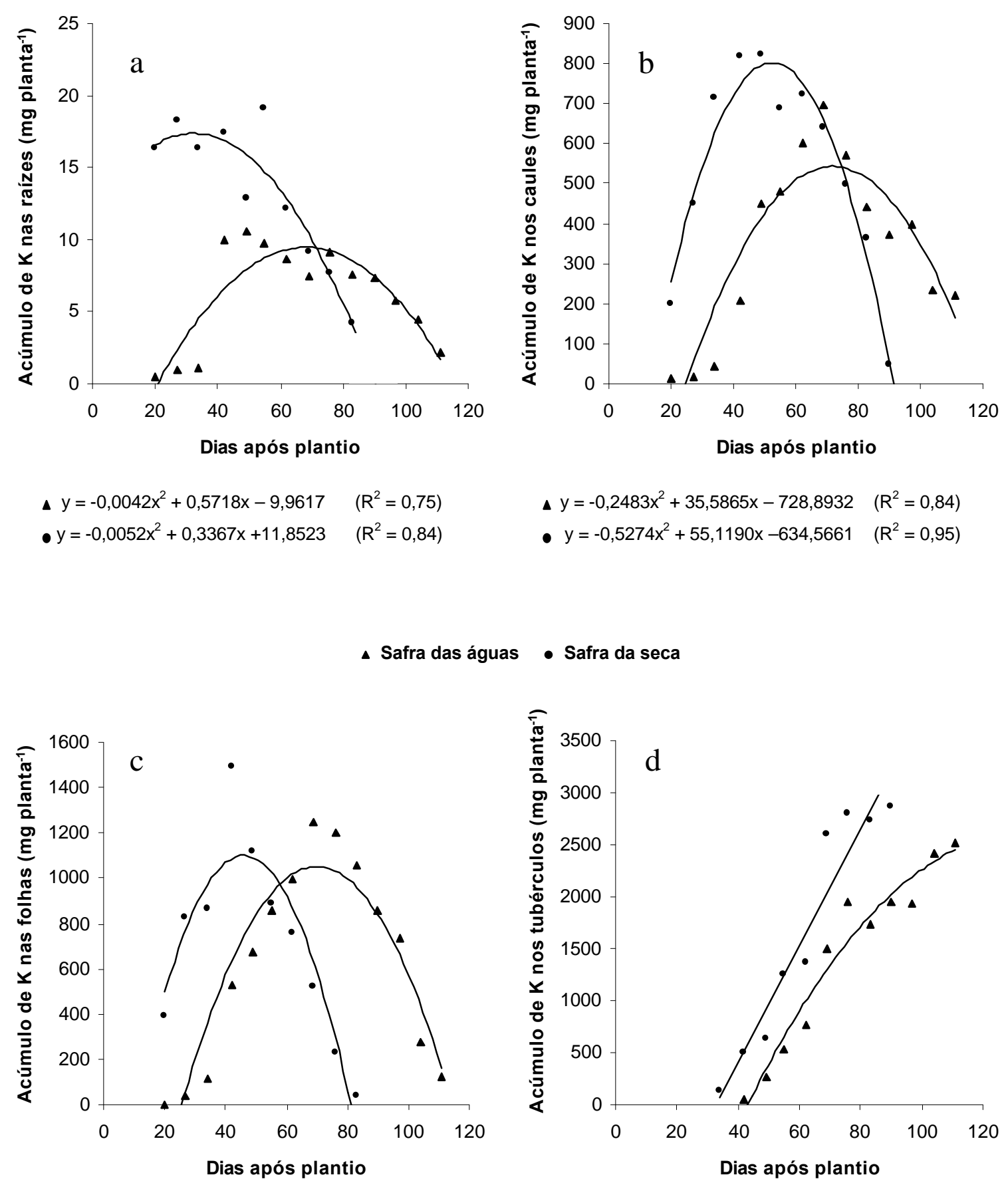

$$
\begin{array}{lr}
\text { \y=-0,5361 } x^{2}+74,9904 x-1563,6925 & \left(R^{2}=0,89\right) \\
\text { - } y=-0,8943 x^{2}+82,1226 x-781,8966 & \left(R^{2}=0,84\right)
\end{array}
$$$$
\begin{array}{ll}
\Delta y=-0,3041 x^{2}+82,3292 x-2933,5893 & \left(R^{2}=0,95\right) \\
\text { - } y=55,5137 x-1793,8728 & \left(R^{2}=0,92\right)
\end{array}
$$

- $y=55,5137 x-1793,8728$

$\left(R^{2}=0,92\right)$

Figura 10 - Potássio acumulado nos órgãos da batateira ao longo do ciclo (mg planta ${ }^{-1}$ ): raízes (a), caules (b), folhas (c) e tubérculos (d). 


\subsubsection{Cálcio}

De acordo com a análise de variância, o acúmulo total de cálcio apresentou significância $(P<0,01)$ e ajustou-se ao modelo quadrático de regressão, nas duas safras (Figura 11).

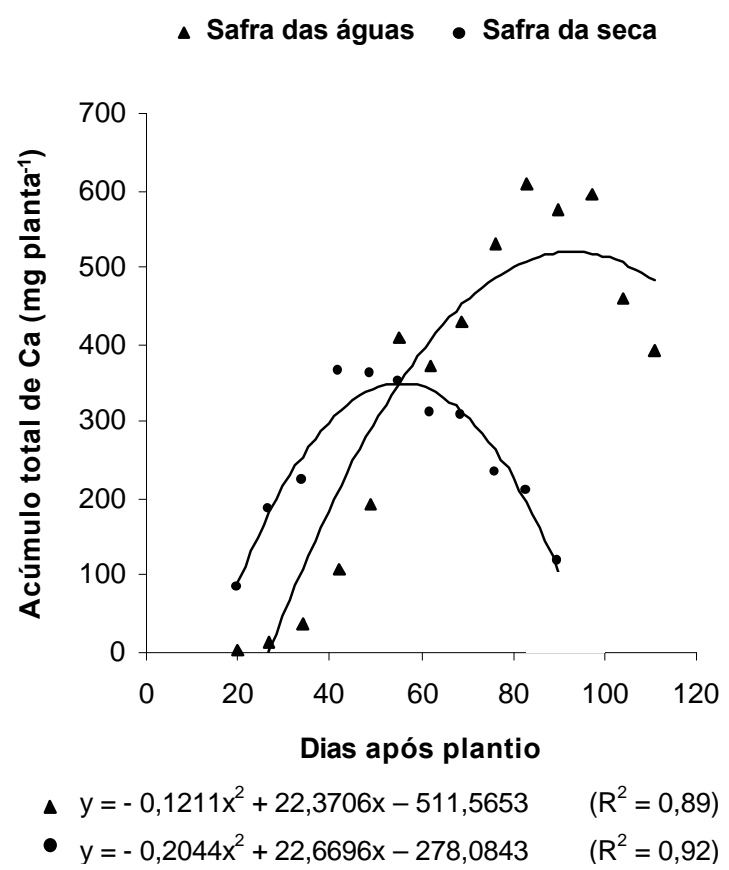

Figura 11 - Cálcio total acumulado na batateira ao longo do ciclo, nas safras das águas e da seca (mg planta ${ }^{-1}$ ).

Na safra das águas, o acúmulo máximo de cálcio total foi de 521,5 $\mathrm{mg}_{\text {planta }}{ }^{-1}$ $\left(21,7 \mathrm{~kg} \mathrm{ha}^{-1}\right)$ aos 92 DAP, com uma exportação de $2,88 \mathrm{~kg} \mathrm{ha}^{-1} \mathrm{e}$, na safra da seca, o acúmulo máximo foi de 350,2 mg planta ${ }^{-1}\left(14,6 \mathrm{~kg} \mathrm{ha}^{-1}\right)$ aos 55 DAP, com uma exportação de $1,77 \mathrm{~kg} \mathrm{ha}^{-1}$, e nas duas safras, o máximo acúmulo de cálcio total ocorreu no enchimento de tubérculos. Hawkins (1946) com a cv. 'Green Mountain', e Ezeta \& McCollum (1972), com a cv. 'Renacimiento', observaram valores de acúmulo máximo maiores $\left(44,8\right.$ e $60 \mathrm{~kg} \mathrm{ha}^{-1}$, respectivamente) do que as observadas neste trabalho, e Paula et al. (1986a), em estudo com as cv. 'Achat' e 'Mantiqueira', observaram valores menores (4,0 e 7,4 $\mathrm{kg} \mathrm{ha}^{-1}$, respectivamente).

A exportação de cálcio na safra das águas e na da seca corresponderam a 13 e $12 \%$ respectivamente do acúmulo máximo total, ao passo que Paula et al. (1986a) verificou que a exportação correspondeu a $5 \%$ do acúmulo máximo total, nas cultivares 
'Achat' e 'Mantiqueira'.

Segundo Fontes (1997), uma tonelada de tubérculos retira do solo, de 0,5 a $1,5 \mathrm{~kg}$ de cálcio. Valores bem menores foram encontrados no presente experimento, tanto na safra das águas $\left(0,08 \mathrm{~kg} \mathrm{t}^{-1}\right)$ quanto na seca $\left(0,07 \mathrm{~kg} \mathrm{t}^{-1}\right)$, porém Feltran \& Lemos (2001) encontraram valores próximos aos deste experimento, para as cultivares 'Asterix' $\left(0,074 \mathrm{~kg} \mathrm{t}^{-1}\right)$, 'Laguna' $\left(0,037 \mathrm{~kg} \mathrm{t}^{-1}\right)$, 'Picasso' $\left(0,049 \mathrm{~kg} \mathrm{t}^{-1}\right)$ e 'Solide' $\left(0,044 \mathrm{~kg} \mathrm{t}^{-1}\right)$.

O acúmulo de cálcio nas raízes, caules e folhas apresentou significância $(\mathrm{P}<0,01)$ e ajustou-se ao modelo quadrático de regressão, já os tubérculos, apresentaram significância $(P<0,01)$ e ajustaram-se ao modelo linear (Figura 12).

Na safra das águas, o acúmulo máximo de cálcio nas raízes, caules, folhas e tubérculos ocorreu aos 74, 93, 87 e 111 DAP e foi de 6,36; 102,8; 375,12 e 56,98 mg planta $^{-1}\left(0,27 ; 4,28 ; 15,63\right.$ e 2,37 $\left.\mathrm{kg} \mathrm{ha}^{-1}\right)$, respectivamente, sendo que esses valores

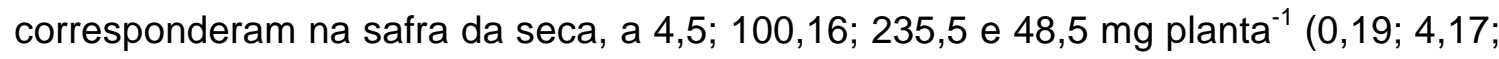
9,81 e $2,02 \mathrm{~kg} \mathrm{ha}^{-1}$ ) e ocorreram aos 48, 65, 51 e 90 DAP.

O acúmulo máximo de cálcio nas raízes, caules e folhas ocorreu no estádio de enchimento de tubérculos, nas duas safras, a única exceção foi para os caules, na safra das águas, que ocorreu na maturação.

Paula et al. (1986a) observaram valores menores de acúmulo máximo de cálcio nas raízes, caules, folhas e tubérculos, para as cultivares 'Achat' $(0,20 ; 0,75 ; 2,9$ e 0,20 $\left.\mathrm{kg} \mathrm{ha}^{-1}\right)$ e 'Mantiqueira' (0,36; 1,47; 5,25 e 0,35 $\left.\mathrm{kg} \mathrm{ha}^{-1}\right)$.

De acordo com os resultados, observou-se que o acúmulo maior de cálcio ocorreu nas folhas, ao contrário do nitrogênio, fósforo e potássio, que ocorreu nos tubérculos, evidenciando o fato do cálcio absorvido pela raiz ser translocado para a parte aérea e não ser redistribuído dentro da planta, devido a sua baixa mobilidade. Tal fato já havia sido relatado por Kratzke \& Palta (1986), em um estudo sobre acúmulo de cálcio nos tubérculos e o papel das raízes basais, observaram que o acúmulo de cálcio nos tubérculos não aumentou com o aumento da dose de cálcio nas raízes basais, separadamente dos estolões e tubérculos e, então, sugeriram que as raízes basais não contribuíram para o acúmulo de cálcio nos tubérculos e que, o cálcio presente nos tubérculos foi absorvido diretamente pelos estolões e por pêlos absorventes existentes nos tubérculos. 
¿ Safra das águas • Safra da seca
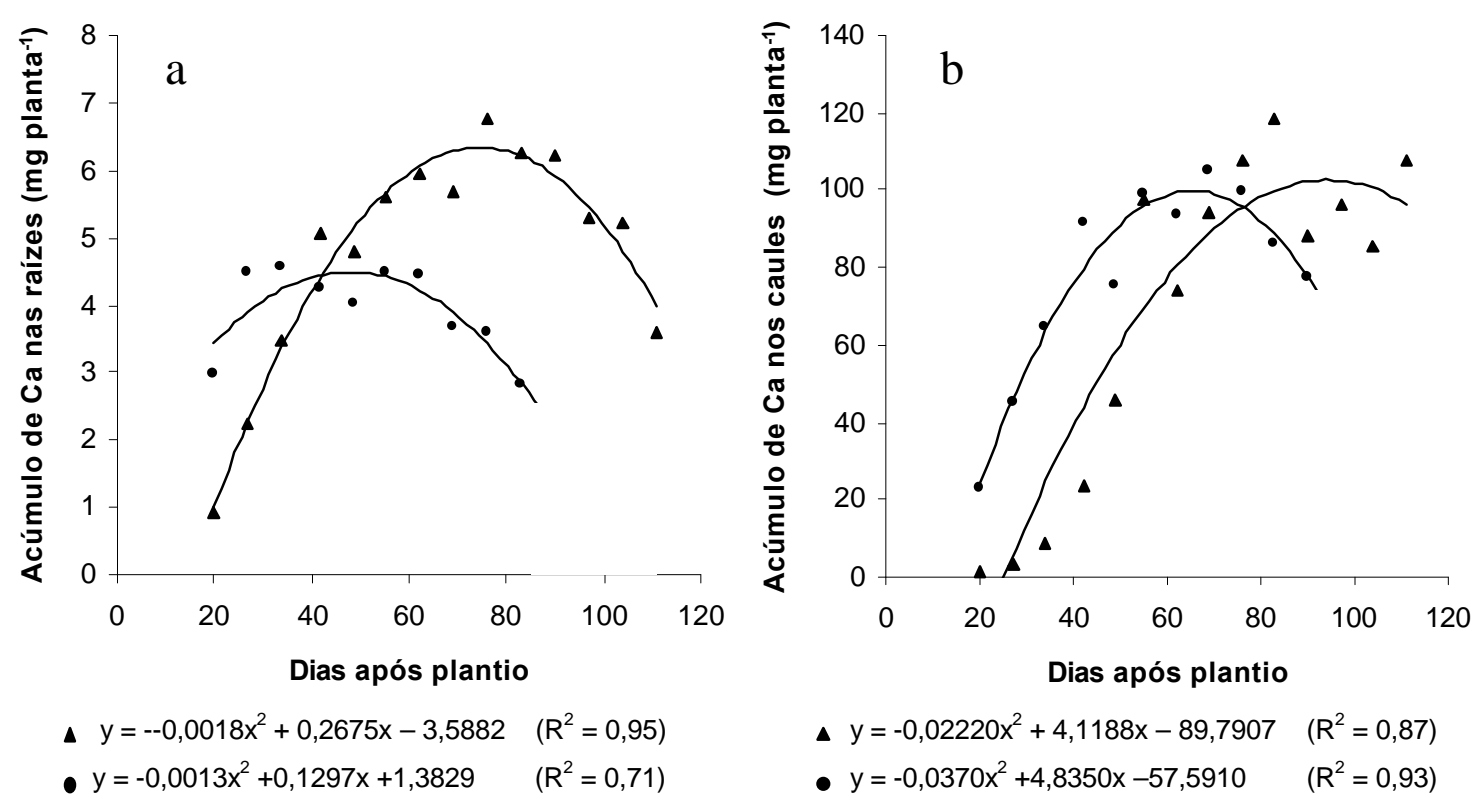

\Safra das águas - Safra da seca
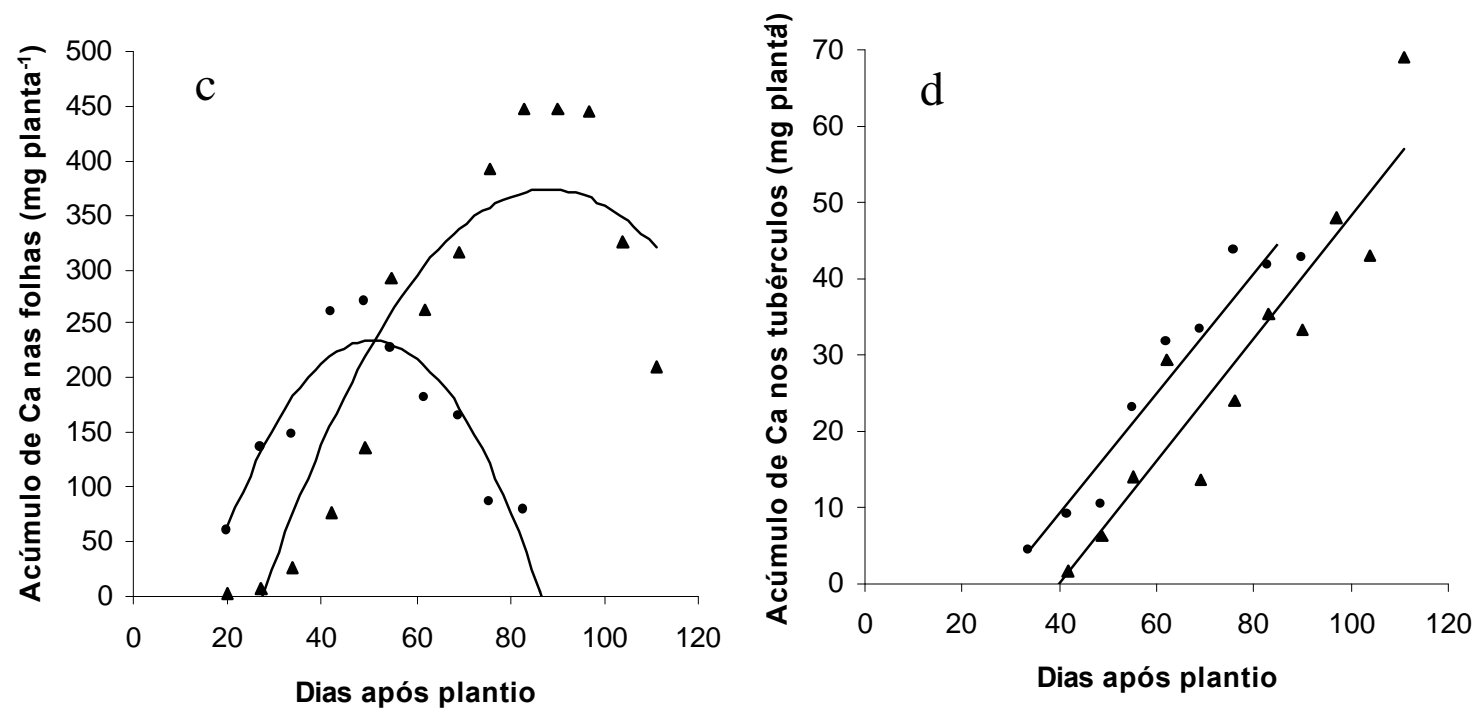

$$
\begin{array}{ll}
\Delta y=-0,1034 x^{2}+18,1137 x-418,4855 & \left(R^{2}=0,85\right) \\
\text { - } y=-0,1826 x^{2}+18,4791 x-232,0644 & \left(R^{2}=0,85\right)
\end{array}
$$
- $y=0,7898 x-30,6851 \quad\left(R^{2}=0,86\right)$
- $y=0,7826 x-21,9333 \quad\left(R^{2}=0,93\right)$

Figura 12 - Cálcio acumulado nos órgãos da batateira ao longo do ciclo (mg planta $\left.{ }^{-1}\right)$ : raízes (a), caules (b), folhas (c) e tubérculos (d). 
Na safra das águas, a taxa maior de acúmulo de cálcio nas raízes ocorreu no crescimento vegetativo, de 20 a 27 DAP, nos caules e folhas, no início do enchimento de tubérculos, de 49 a 55 DAP e nos tubérculos, na maturação, de 105 a 111 DAP.

$\mathrm{Na}$ safra da seca, a taxa maior de acúmulo de cálcio nas raízes ocorreu no crescimento vegetativo, da emergência até 20 DAP, nas folhas e caules no início do enchimento de tubérculos de 35 a 41 DAP e nos tubérculos, na metade da mesma fase de 49 a 55 DAP.

A taxa maior de acúmulo de cálcio nos tubérculos na safra das águas foi de $1,08 \mathrm{~kg} \mathrm{ha}^{-1}$ de 105 a 111 DAP, já nas folhas, a taxa maior foi de $6,49 \mathrm{~kg} \mathrm{ha}^{-1}$ de $49 \mathrm{a}$ 55 DAP. Na safra da seca, as taxas foram menores $\left(0,52\right.$ e 4,62 $\left.\mathrm{kg} \mathrm{ha}^{-1}\right)$ e ocorreram de 49 a 55 DAP e de 35 a 41 DAP, respectivamente. Hawkins (1946) observou uma taxa maior nos tubérculos $\left(1,2 \mathrm{~kg} \mathrm{ha}^{-1}\right)$, com a cv. 'Green Mountain', no período de 71 a 81 DAP.

\subsubsection{Magnésio}

A análise de variância mostrou significância $(P<0,01)$ para o acúmulo total de magnésio, ajustando-se ao modelo quadrático de regressão nas duas safras (Figura 13).

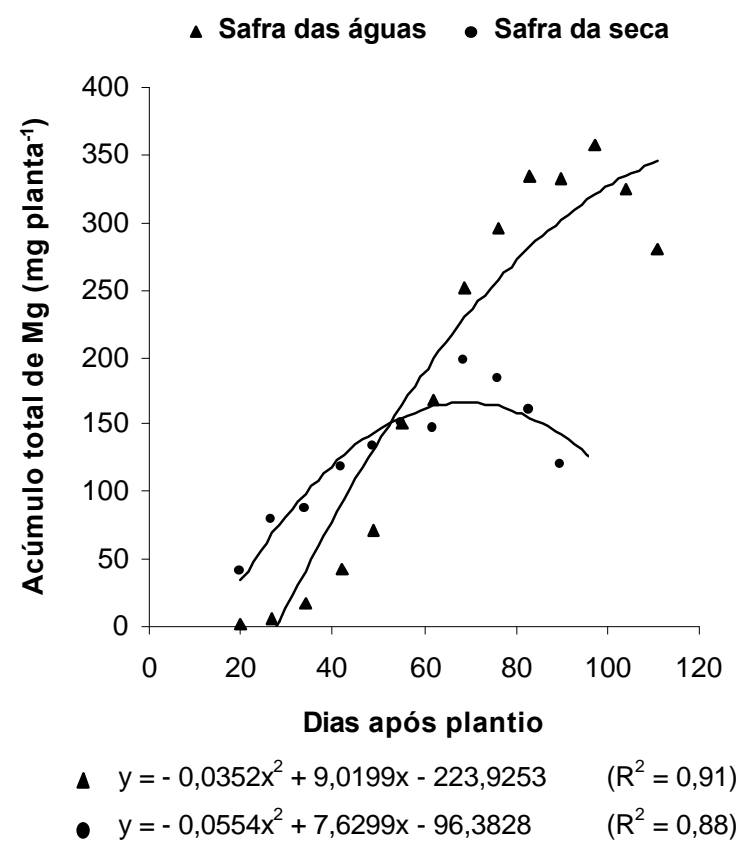

Figura 9 - Magnésio total acumulado na batateira ao longo do ciclo, nas safras das águas e da seca (mg planta $\left.{ }^{-1}\right)$. 
$\mathrm{Na}$ safra das águas, o acúmulo máximo de magnésio total foi de $344 \mathrm{mg}$ planta $^{-1}\left(14,3 \mathrm{~kg} \mathrm{ha}^{-1}\right)$ aos 111 DAP, ocorrendo na maturação e, na safra da seca, de 166,4 mg planta ${ }^{-1}\left(6,9 \mathrm{~kg} \mathrm{ha}^{-1}\right)$ aos 69 DAP, no enchimento de tubérculos. Ezeta \& McCollum (1972) com a cv. 'Renacimiento', relataram que o cálcio e o magnésio tiveram comportamentos semelhantes durante o ciclo e, que o acúmulo máximo de magnésio foi de $31 \mathrm{~kg} \mathrm{ha}^{-1}$ aos 137 DAP e Paula et al. (1986a) observaram valores de 4,8 e 2,4 $\mathrm{kg} \mathrm{ha}^{-1}$ de acúmulo de magnésio nas cultivares 'Mantiqueira' e 'Achat', respectivamente.

As exportações de magnésio nas safras das águas e da seca corresponderam a 37 e $61 \%$ do acúmulo máximo total e Paula et al. (1986a) observaram valores de 65 e $82 \%$ para as cv. 'Mantiqueira' e 'Achat', respectivamente.

Com relação àremoção por tonelada de tubérculos, observa -se que na safra das águas, foi removido do solo $0,24 \mathrm{~kg} \mathrm{t}^{-1}$ de magnésio e na seca, 0,25 $\mathrm{kg} \mathrm{t}^{-1}$. Esses valores confirmam os relatados por Fontes (1997), de 0,1 a 0,3 $\mathrm{kg} \mathrm{t}^{-1}$. Feltran \& Lemos (2001) encontraram valores próximos aos de Fontes, nas cultivares 'Asterix' $\left(0,206 \mathrm{~kg} \mathrm{t}^{-1}\right)$, 'Laguna' $\left(0,164 \mathrm{~kg} \mathrm{t}^{-1}\right)$, 'Picasso' $\left(0,152 \mathrm{~kg} \mathrm{t}^{-1}\right)$ e 'Solide' 0,221 kg t $\left.{ }^{-1}\right)$.

O acúmulo de magnésio nas raízes, caules e folhas apresentaram significância $(P<0,01)$ e ajustaram-se ao modelo quadrático de regressão, já nos tubérculos, apresentou significância $(P<0,01)$ e ajustou-se ao modelo linear (Figura 14).

Na safra das águas, o acúmulo máximo de magnésio nas raízes, caules, folhas e tubérculos ocorreu aos 81,109 e 84 e 111 DAP e foi de 1,33; 95,63; 140,99 e 129,66 mg planta $^{-1}\left(0,06 ; 3,98 ; 5,87\right.$ e 5,04 $\left.\mathrm{kg} \mathrm{ha}^{-1}\right)$, respectivamente, e esses valores corresponderam na safra da seca, a 1,13; 51,67; 65,67 e 116,67 mg planta ${ }^{-1}(0,05$; 2,15; 2,74 e 4,86 $\mathrm{kg} \mathrm{ha}^{-1}$ ) aos 46, 63, 46 e 90 DAP. Paula et al. (1986a) observaram que o acúmulo máximo de magnésio, tanto para a cv. 'Achat' como para a cv. 'Mantiqueira', ocorreu nos tubérculos (1,97 e 3,11 $\mathrm{kg} \mathrm{ha}^{-1}$, respectivamente).

Nas duas safras, o acúmulo máximo de magnésio nas raízes, caules e folhas ocorreu no estádio de enchimento de tubérculos, com única exceção para os caules na safra das águas, que ocorreu na maturação.

Na safra das águas, a taxa maior de acúmulo de magnésio nas raízes, caules e folhas, ocorreu no enchimento de tubérculos, de 63 a 76 DAP. 

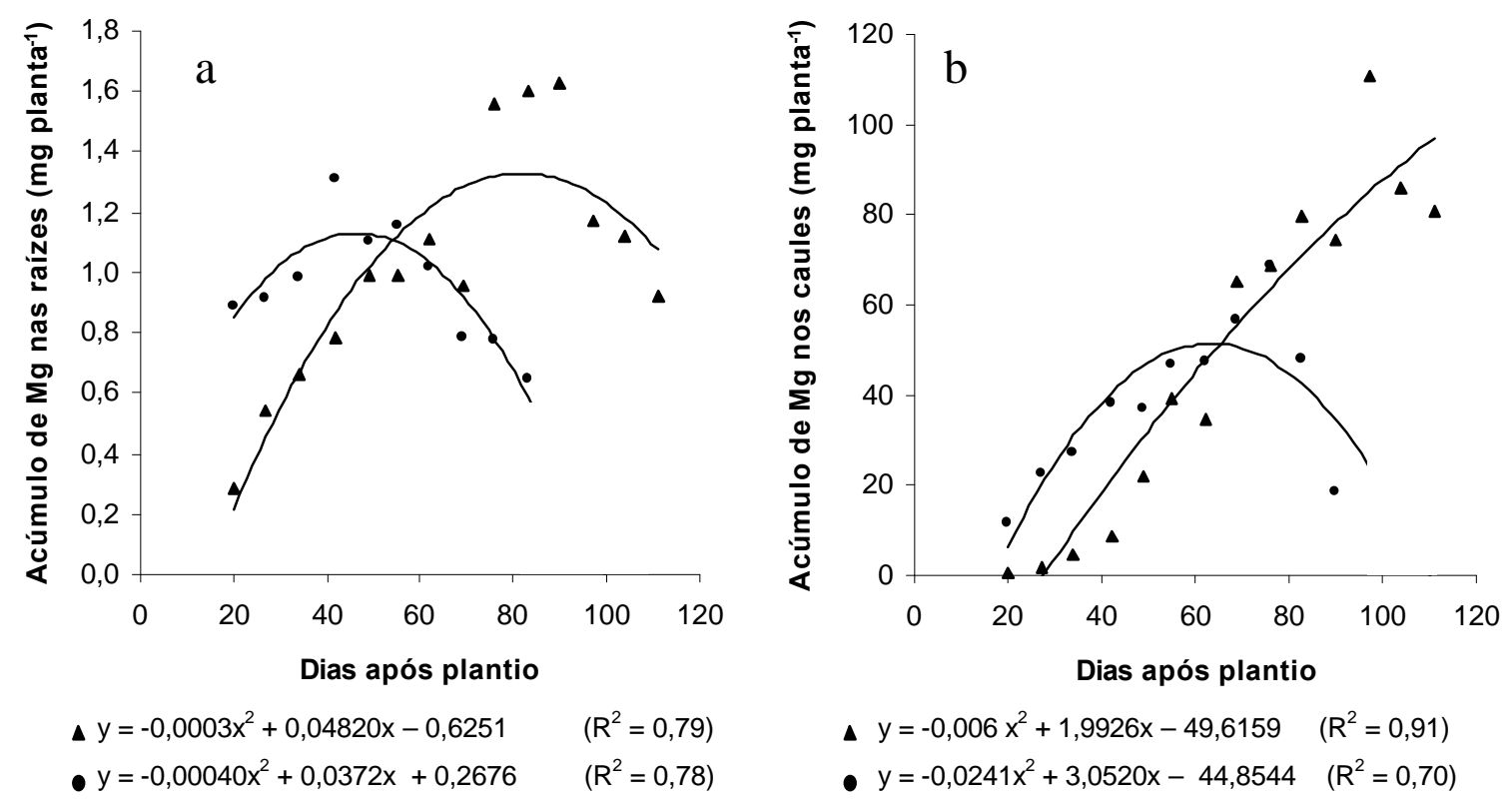

\section{\Safra das águas - Safra da seca}
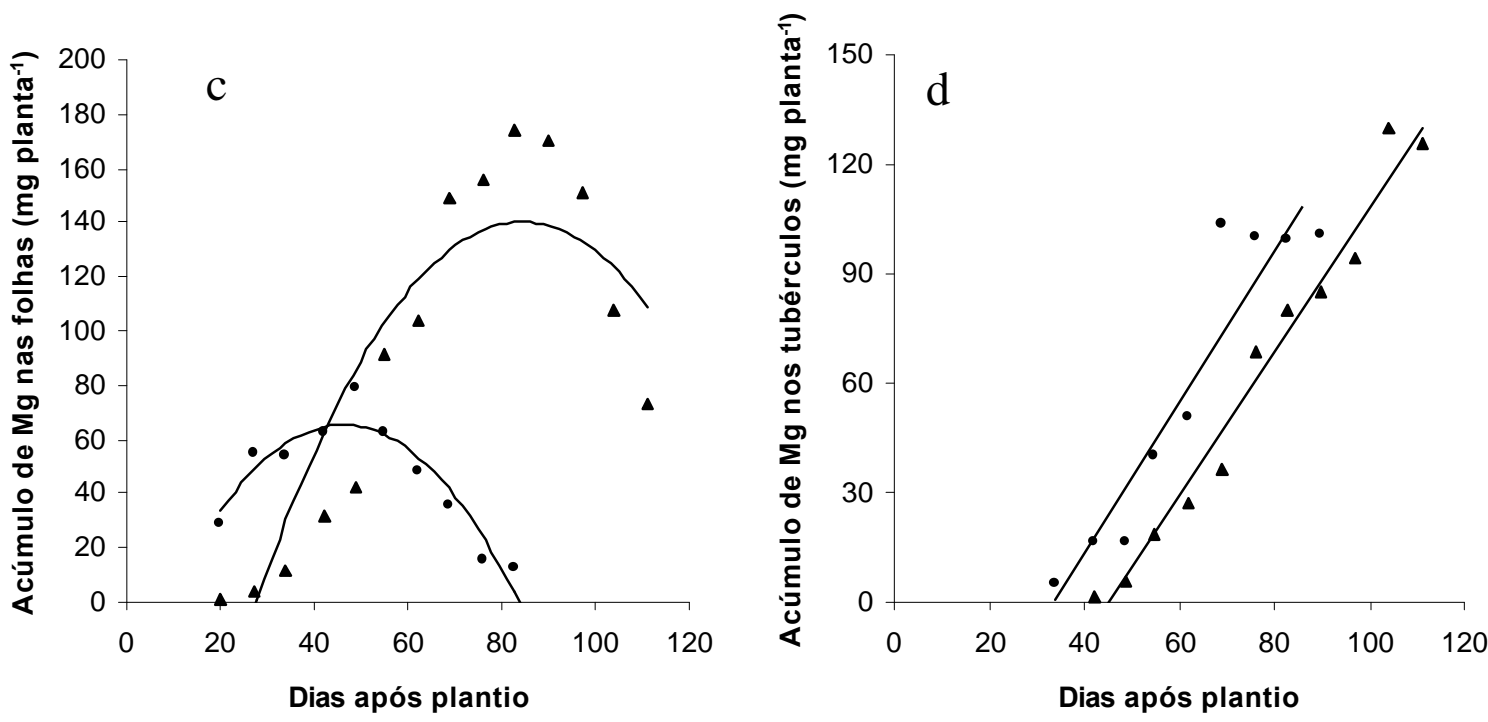

$$
\begin{array}{ll}
\Delta y=-0,0445 x^{2}+7,4612 x-171,7661 & \left(R^{2}=0,82\right) \\
\text { - } y=-0,04655 x^{2}+4,3002 x-33,6387 & \left(R^{2}=0,88\right)
\end{array}
$$

$$
\begin{array}{ll}
\text { A } y=1,9570 x-87,5675 & \left(R^{2}=0,97\right) \\
\text { - } y=2,0622 x-68,9290 & \left(R^{2}=0,88\right)
\end{array}
$$

Figura 14 - Magnésio acumulado nos órgãos da batateira ao longo do ciclo (mg planta ${ }^{-1}$ ): raízes (a), caules (b), folhas (c) e tubérculos (d). 
Já na safra da seca, a taxa maior de acúmulo de magnésio nas raízes ocorreu no início do enchimento de tubérculos, de 35 a 41 DAP, nas folhas, na maturação, de 70 a 76 DAP e nos caules, na tuberização, de 20 a 27 DAP.

A taxa maior de acúmulo de magnésio nos tubérculos na safra das águas foi de $1,37 \mathrm{~kg} \mathrm{ha}^{-1}$, de 98 a 104 DAP e na safra da seca, de 0,99 kg ha-1, de 63 a 69 DAP. Já Hawkins (1946), com a cv. 'Green Mountain', observou valores de 3,23 kg ha-1 de 92 a 101 DAP.

\subsubsection{Enxofre}

O acúmulo total de enxofre apresentou significância $(P<0,01)$ e ajustou-se ao modelo quadrático de regressão, nas duas safras (Figura 15).

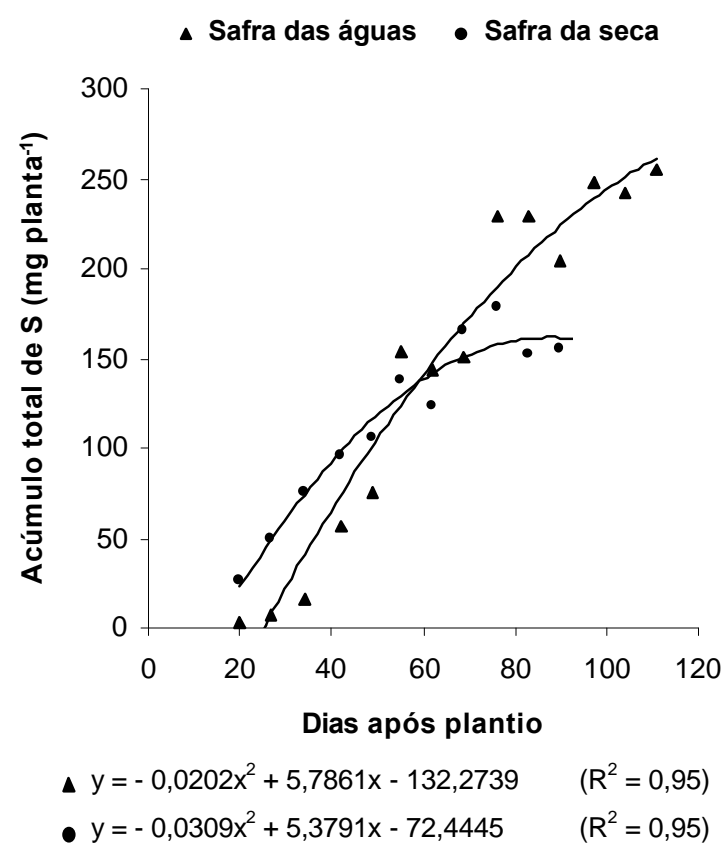

Figura 9 - Enxofre total acumulado na batateira ao longo do ciclo nas safras das águas e da seca (mg planta $\left.{ }^{-1}\right)$.

O acúmulo máximo de enxofre total foi de $260,6 \mathrm{mg} \mathrm{planta}^{-1}\left(10,8 \mathrm{~kg} \mathrm{ha}^{-1}\right)$ aos 111 DAP na safra das águas e, na safra da seca, de 161,4 $\mathrm{mg} \mathrm{planta}^{-1}\left(6,7 \mathrm{~kg} \mathrm{ha}^{-1}\right)$ aos 87 DAP, em ambos ocorreu na maturação. Hawkins (1946) observou um valor maior (12 kg ha-1) em relação aos deste experimento, com a cv. 'Green Mountain', assim 
como Gargantini et al. (1963), com a cv. 'Bintje' (13 kg ha-1). Já Paula et al. (1986a) observaram valores menores de acúmulo máximo de enxofre, com as cultivares 'Achat' $\left(2,54 \mathrm{~kg} \mathrm{ha}^{-1}\right)$ e 'Mantiqueira' (4,58 kg ha-1).

A exportação de enxofre na safra das águas foi $81 \%$ do acúmulo máximo total e na safra da seca, 88\%. Hawkins (1946) encontrou, com a cv. 'Green Mountain', 56\%; Gargantini et al. (1963) - 46\% com 'Bintje' e Paula et al.(1986a) - 79 e 88\%, nas cv. 'Mantiqueira' e 'Achat', respectivamente.

A remoção de enxofre por tonelada de tubérculos foi de 0,24 $\mathrm{kg}$ na safra das águas e 0,25 na safra da seca. Esses valores são menores do que os relatados por Fontes (1997), de 0,3 a 0,8 $\mathrm{kg} \mathrm{t}^{-1}$.

O acúmulo de enxofre nas raízes, caules e folhas apresentou significância $(P<0,01)$, ajustando-se ao modelo quadrático de regressão $e$, nos tubérculos, apresentou significância $(P<0,01)$, ajustando-se ao modelo linear de regressão (Figura 16).

O acúmulo máximo de enxofre nas raízes, caules, folhas e tubérculos ocorreu aos $67,74,71$ e 111 DAP e foi de 1,$72 ; 26,07 ; 71,98$ e 211,97 mg planta $^{-1}(0,07 ; 1,09$; 3 e $8,83 \mathrm{~kg} \mathrm{ha}^{-1}$ ), respectivamente, na safra das águas e, esses valores corresponderam na safra da seca, a 1,72; 28,06; 45,03 e 163,85 mg planta ${ }^{-1}(0,07$; 1,$17 ; 1,88$ e 6,83 $\mathrm{kg} \mathrm{ha}^{-1}$ ) aos 47, 53, 45 e 90 DAP. Resultados observados por Paula et al. (1986a) foram bem menores, para todos os órgãos, para as cultivares 'Achat' $\left(0,034 ; 0,08 ; 0,18\right.$ e 2,25 kg ha-1) e 'Mantiqueira' $\left(0,061 ; 0,24 ; 0,63\right.$ e 3,63 $\mathrm{kg} \mathrm{ha}^{-1} \mathrm{de}$ enxofre, referentes a raízes, caules, folhas e tubérculos, respectivamente).

Nas duas safras, o acúmulo máximo de enxofre nas raízes, caules e folhas ocorreu no estádio de enchimento de tubérculos e, nos tubérculos, na maturação.

Na safra das águas, a taxa maior de acúmulo de enxofre nos caules e folhas ocorreu no início do enchimento de tubérculos, de 49 a 55 DAP, nas raízes, na metade da mesma fase, de 70 a 76 DAP e nos tubérculos, na maturação, de 91 a 97 DAP.

Já na safra da seca, a taxa maior de acúmulo de enxofre nos caules ocorreu no início do enchimento de tubérculos, de 35 a 41 DAP, nas raízes na metade da mesma fase, de 49 a 55 DAP e para os tubérculos, no final, de 63 a 69 DAP. Quanto \&̀ folhas, a taxa maior de acúmulo ocorreu na tuberização, de 20 a 27 DAP.

A taxa maior de acúmulo de enxofre nos tubérculos foi de $53,11 \mathrm{mg} \mathrm{planta}^{-1}$ $\left(2,21 \mathrm{~kg} \mathrm{ha}^{-1}\right)$ na safra das águas e foi muito próxima àda safra seca, $58,43 \mathrm{mg} \mathrm{planta}^{-1}$ 
$\left(2,43 \mathrm{~kg} \mathrm{ha}{ }^{-1}\right)$. Hawkins (1946) observou um valor de taxa maior semelhante $\left(2,5 \mathrm{~kg} \mathrm{ha}^{-1}\right)$ com a cultivar 'Green Mountain'.

- Safra das águas - Safra da seca
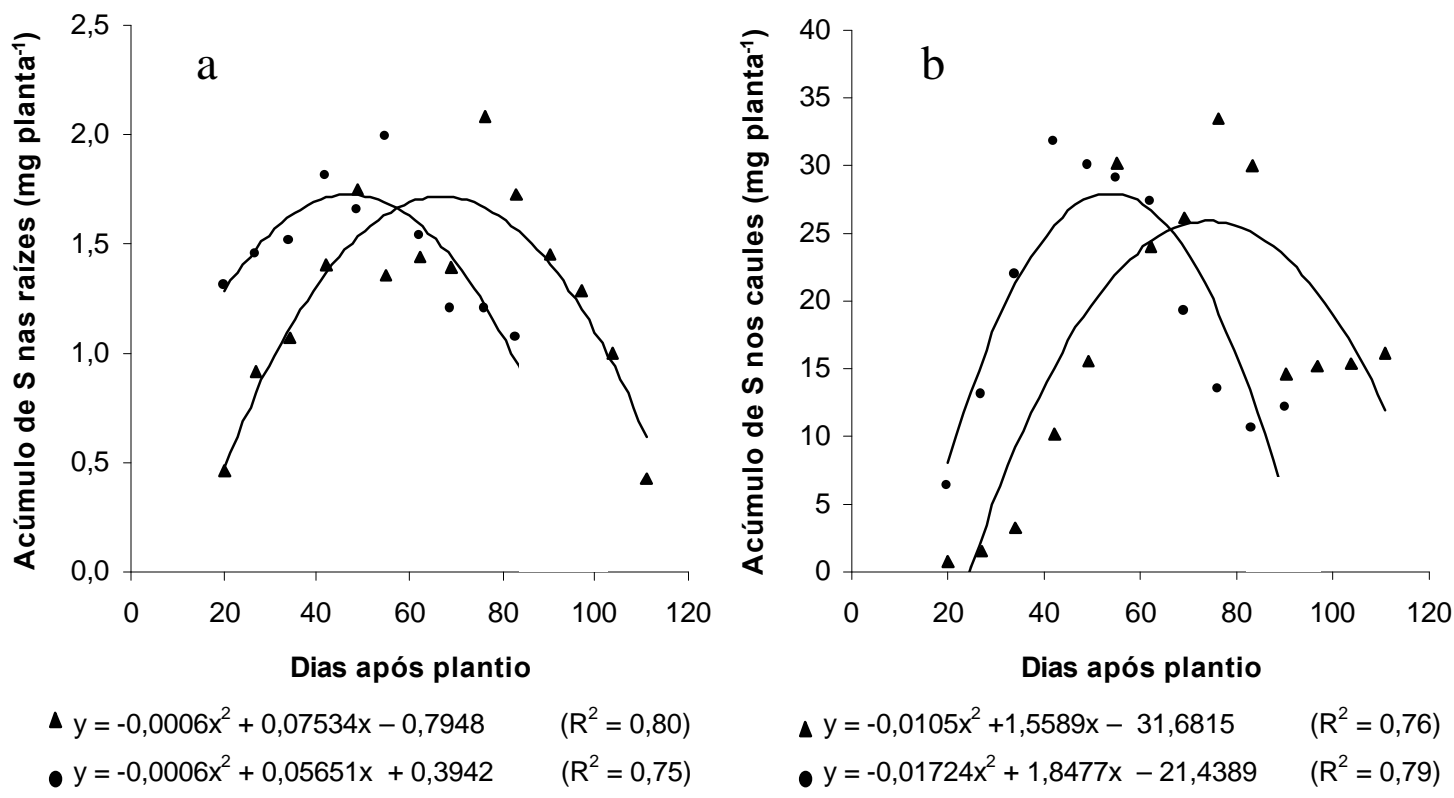

- Safra das águas

- Safra da seca
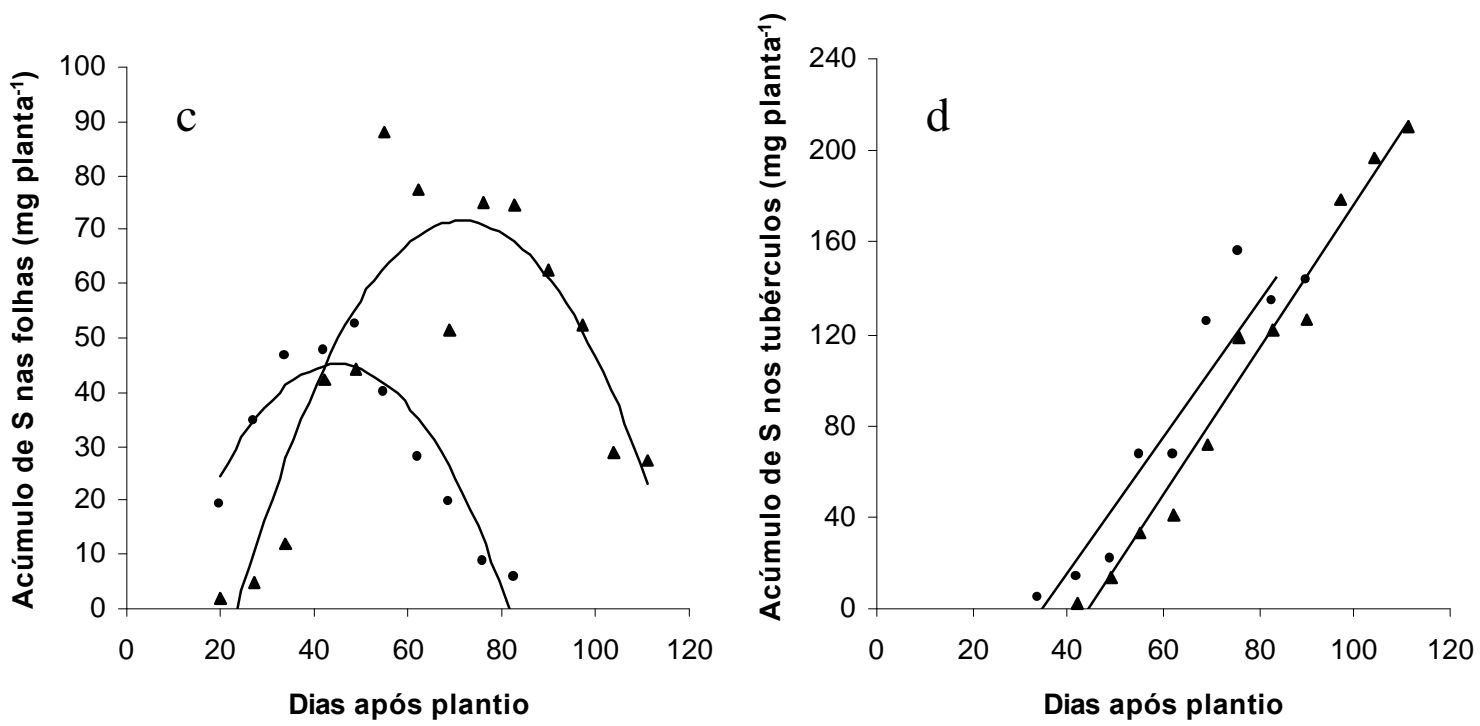

$\Delta y=-0,03136 x^{2}+4,4818 x-88,1673 \quad\left(R^{2}=0,82\right)$

- $y=-0,03312 x^{2}+2,9779 x-21,8926 \quad\left(R^{2}=0,87\right)$
A $y=3,1591 x-138,6890$
$\left(R^{2}=0,98\right)$
- $y=2,9579 x-102,3629$
$\left(R^{2}=0,90\right)$

Figura 16 - Enxofre acumulado nos órgãos da batateira ao longo do ciclo (mg planta ${ }^{-1}$ ): raízes (a), caules (b), folhas (c) e tubérculos (d). 


\subsection{Acúmulo e exportação de micronutrientes}

\subsubsection{Boro}

De acordo com a análise de variância, o acúmulo total de boro apresentou significância $(P<0,01)$ e ajustou-se ao modelo quadrático de regressão, nas duas safras (Figura 17).

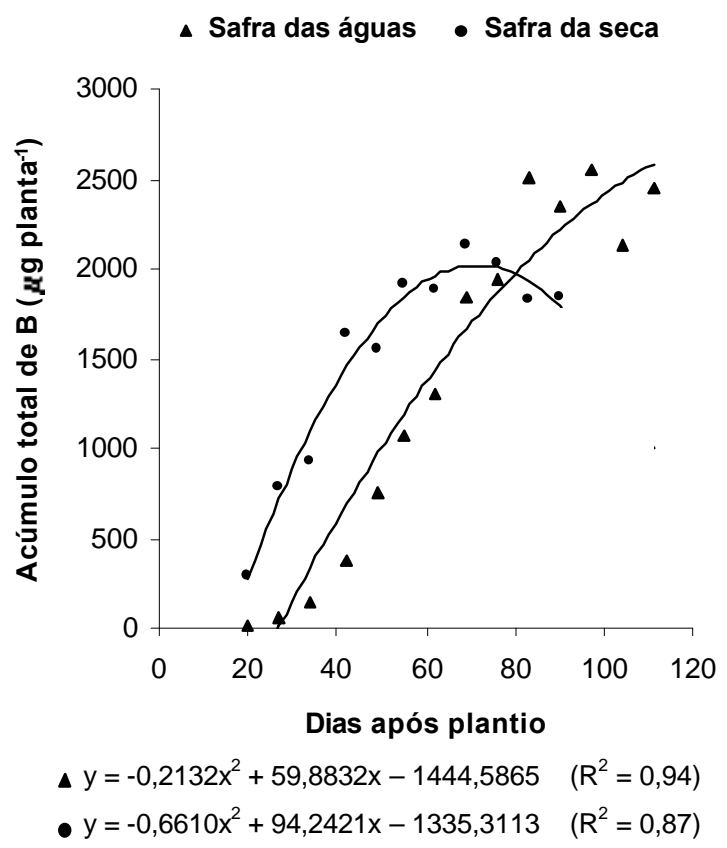

Figura 16 - Boro total acumulado na batateira ao longo do ciclo, nas safras das águas e da seca $\left(\mu \mathrm{g}_{\text {planta }}{ }^{-1}\right)$.

Na safra das águas, o acúmulo máximo de boro total foi de 2.574,82 $\mu \mathrm{g} \mathrm{planta}^{-1}$ $\left(107,28 \mathrm{~g} \mathrm{ha}^{-1}\right)$ aos 111 DAP e, na safra da seca, de 2.023,69 $\mu \mathrm{g} \mathrm{planta}^{-1}\left(84,32 \mathrm{~g} \mathrm{ha}^{-1}\right)$ aos 71 DAP, sendo que ambos ocorreram na maturação. Paula et al. (1986b) relataram valores bem menores, (33,27 e 17,73 $\left.\mathrm{g} \mathrm{ha}^{-1}\right)$ para as cultivares 'Achat' e 'Mantiqueira'.

A exportação na safra das águas foi de $67 \%$ do acúmulo máximo total de boro (72 $\left.\mathrm{g} \mathrm{ha}^{-1}\right)$ e, na safra da seca, 79\% (67 $\mathrm{g} \mathrm{ha}^{-1}$ ). Paula et al. (1986b) observou exportação de 67\%, para cv. 'Mantiqueira' (22,2 $\left.\mathrm{g} \mathrm{ha}^{-1}\right)$ e de $70 \%$ para 'Achat' $\left(12,4 \mathrm{~g} \mathrm{ha}^{-1}\right)$.

A remoção de boro por tonelada de tubérculo foi de 1,99 $\mathrm{g}$ na safra das águas e, 2,8 g na safra da seca. Esses valores são superiores aos relatados por Fontes 
(1997), de 0,6 a 1,5 $\mathrm{g} \mathrm{t}^{-1}$, porém Feltran \& Lemos (2001) também encontraram valores próximos aos deste experimento, para as cultivares 'Asterix' $\left(2,142 \mathrm{~g} \mathrm{t}^{-1}\right)$, 'Laguna' $\left(1,657 \mathrm{~g} \mathrm{t}^{-1}\right)$, 'Picasso' (2,311 $\left.\mathrm{g} \mathrm{t}^{-1}\right)$ e 'Solide' (1,981 $\left.\mathrm{g} \mathrm{t}^{-1}\right)$.

O acúmulo de boro nas raízes, caules e folhas apresentou significância $(P<0,01)$ e ajustou-se ao modelo quadrático de regressão, já nos tubérculos, ajustou-se ao modelo linear de regressão na safra das águas e ao modelo quadrático na safra da seca (Figura 18).

Na safra das águas, o acúmulo máximo de boro nas raízes, caules e folhas ocorreu aos 67, 40 e 80 DAP e foi de 20,52, 298,78 e 644,65 g planta $^{-1}(0,86,12,45$ e $26,86 \mathrm{~g} \mathrm{ha}^{-1}$ ) respectivamente, e esses valores corresponderam na safra da seca, a 21,09; 423,87 e 642,24 $\mu$ g planta $^{-1}$ (0,88, 17,66 e 26,76 $\left.\mathrm{g} \mathrm{ha}^{-1}\right)$ aos 40, 56 e 47 DAP. Nas duas safras, o acúmulo máximo de boro nas raízes, caules e folhas ocorreu no estádio de enchimento de tubérculos, com exceção do caule na safra das águas. Paula et al. (1986b) observaram valores diferentes de acúmulo máximo nas raízes, caules e folhas, para as cultivares 'Achat' e 'Mantiqueira' $(0,53 ; 0,85$ e $3,95 \mathrm{~g} \mathrm{ha}^{-1}$ e 1,08; 2,85 e 7,14 $\mathrm{g} \mathrm{ha}^{-1}$, respectivamente).

Quanto aos tubérculos, o acúmulo máximo de boro foi de 1.805,89 $\mu \mathrm{g}_{\text {planta }}{ }^{-1}$ $\left(75,25 \mathrm{~g} \mathrm{ha}^{-1}\right), 111$ DAP na safra das águas e, de 1.642,22 $\mu$ g planta $^{-1}\left(68,43 \mathrm{~g} \mathrm{ha}^{-1}\right)$ aos 90 DAP na safra da seca, ambos na maturação. Valores menores foram observados nas cultivares 'Achat' e 'Mantiqueira' (22,2 e 12,4 $\mathrm{g}$ ha' ${ }^{-1}$ de boro).

$\mathrm{Na}$ safra das águas, a taxa maior de acúmulo de boro nas raízes e caules ocorreram na tuberização, de 35 a 41 , e de 42 a 48 DAP, respectivamente e, nas folhas e tubérculos, no enchimento de tubérculos, de 63 a 69, e de 77 a 83 DAP, respectivamente.

Já na safra da seca, a taxa maior de acúmulo de boro nas raízes ocorreu no crescimento vegetativo, da emergência até 20 DAP, nos caules, na tuberização, de 20 a 27 DAP, nas folhas e tubérculos, no enchimento de tubérculos, de 35 a 41 e de 49 a 55 DAP. 
^Safra das águas - Safra da seca
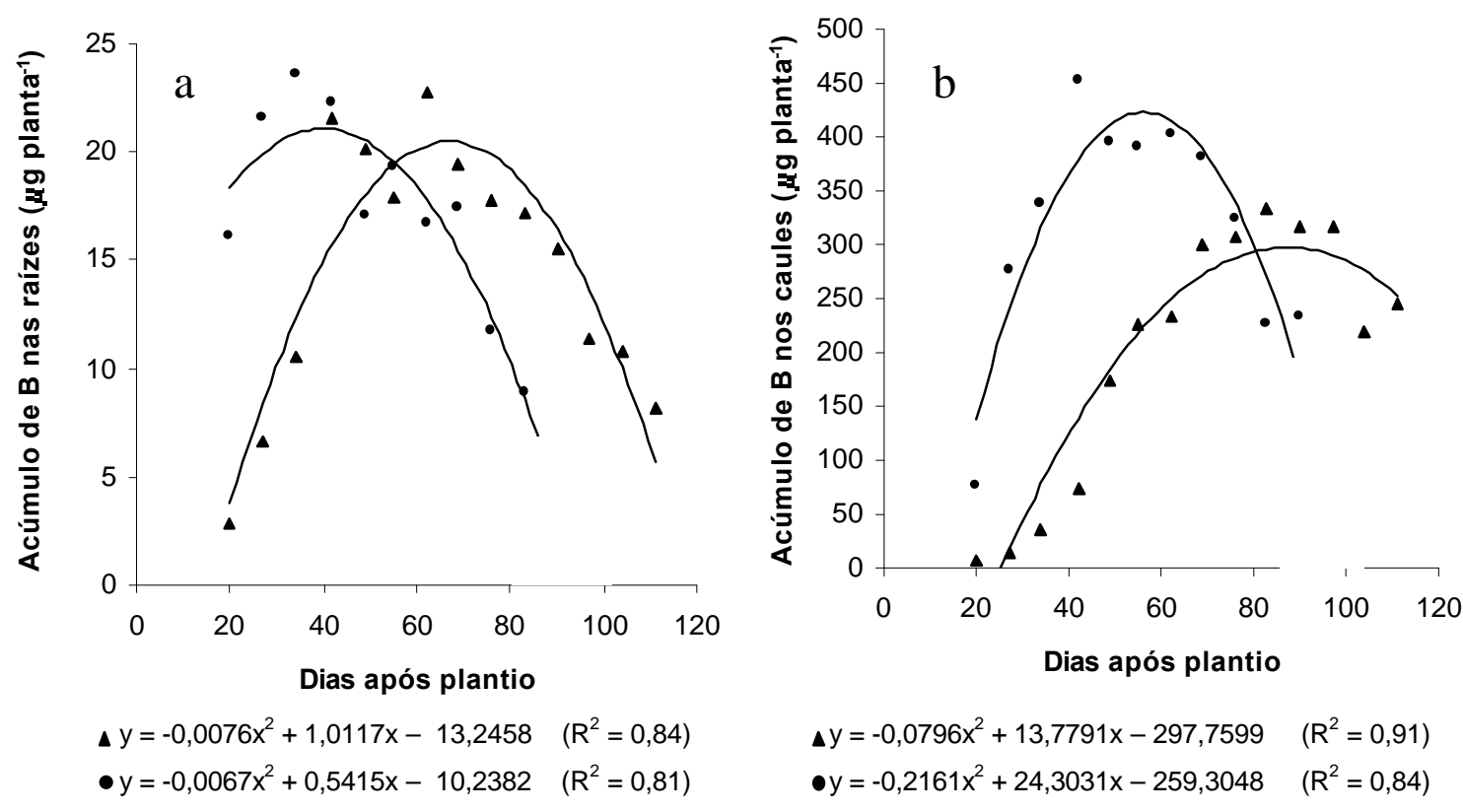

\Safra das águas - Safra da seca
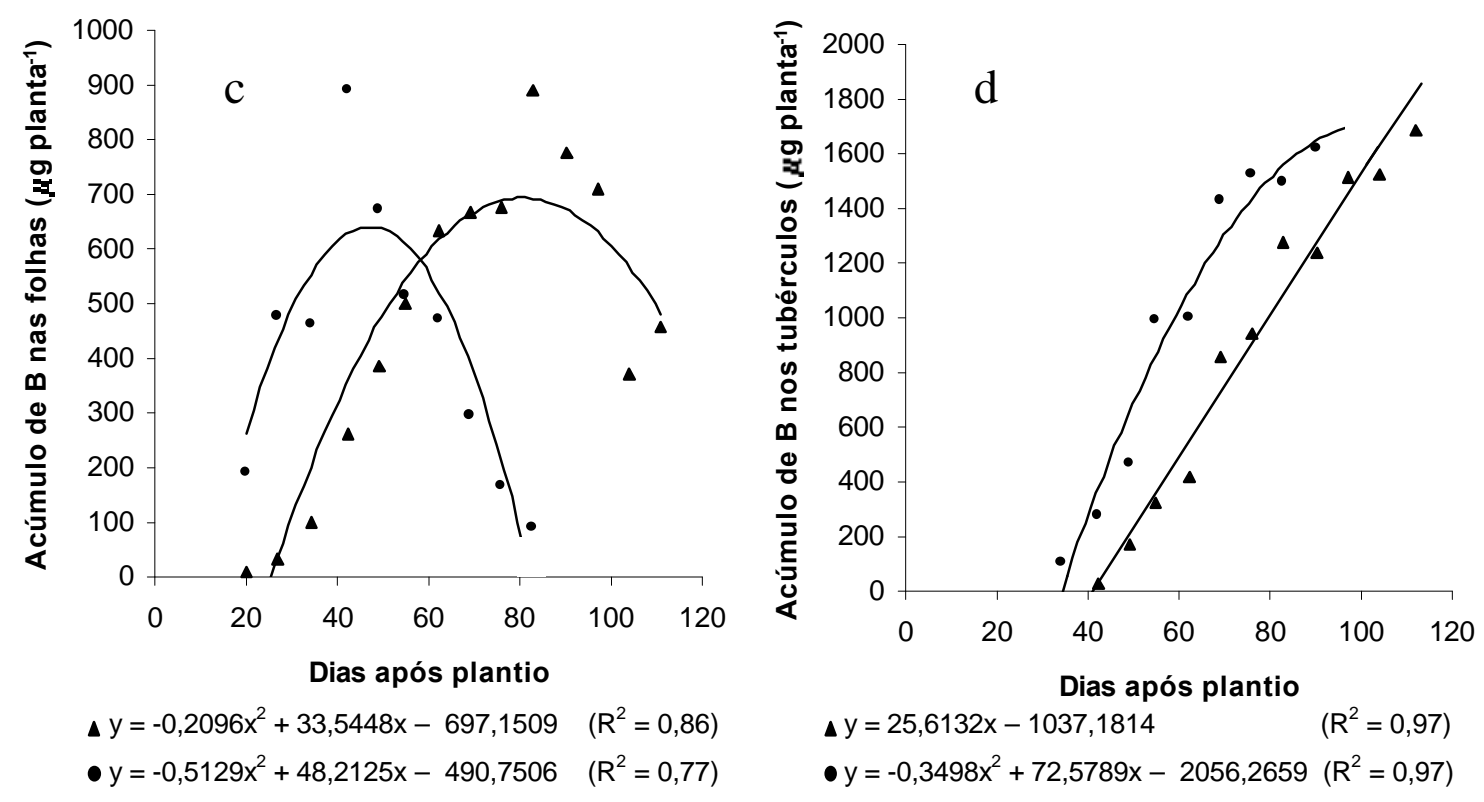

Figura 18 - Boro acumulado nos órgãos da batateira ao longo do ciclo ( $\mu$ g planta $\left.{ }^{-1}\right)$ : raízes (a), caules (b), folhas (c) e tubérculos (d). 


\subsubsection{Cobre}

De acordo com a análise de variância, o acúmulo total de cobre apresentou significância $(P<0,01)$, ajustando-se ao modelo quadrático de regressão, nas duas safras (Figura 19).

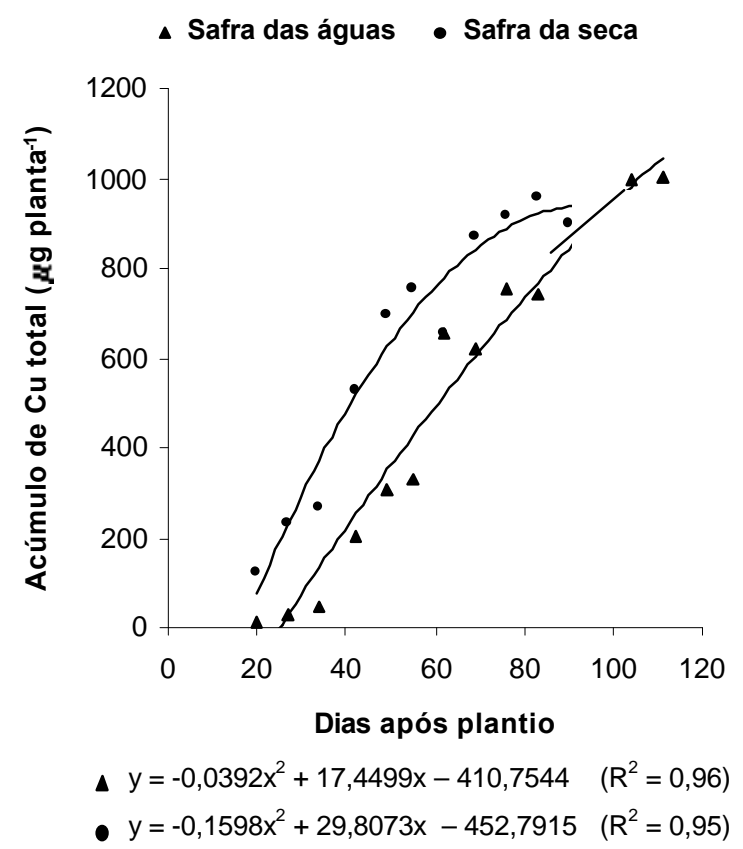

Figura 19 - Cobre total acumulado na batateira ao longo do ciclo, nas safras das águas e da seca ( $\mu$ g planta $\left.{ }^{-1}\right)$.

Na safra das águas, o acúmulo máximo de cobre total foi de1.043,56 $\mu \mathrm{g} \mathrm{planta}^{-1}$ $\left(43,5 \mathrm{~g} \mathrm{ha}^{-1}\right)$ aos $111 \mathrm{DAP}$, que foi maior do que na safra da seca, de 934,84 $\mu \mathrm{g} \mathrm{planta}^{-1}$ (38,9 $\left.\mathrm{g} \mathrm{ha}^{-1}\right)$ aos 90 DAP, e ambos ocorreram na maturação. Paula et al. (1986b) observaram valores de acúmulo menores em relação aos deste experimento para as cv. 'Mantiqueira' (22,4 $\left.\mathrm{g} \mathrm{ha}^{-1}\right)$ e 'Achat' (18 $\left.\mathrm{g} \mathrm{ha}^{-1}\right)$.

A exportação de cobre na safra das águas foi de $31 \mathrm{~g} \mathrm{ha}^{-1}$ e na safra da seca, de $35 \mathrm{~g} \mathrm{ha}^{-1}$. Pode-se observar que, apesar da produtividade na safra das águas ser maior do que na da seca, a exportação foi menor. Então, pode-se observar que a concentração de cobre nos tubérculos foi maior na safra da seca do que na safra das águas. Paula et al. (1986b) encontraram valores menores em relação aos deste experimento, para as cv. 'Mantiqueira' (16,03 $\left.\mathrm{g} \mathrm{ha}^{-1}\right)$ e 'Achat' (12,4 $\left.\mathrm{g} \mathrm{ha}^{-1}\right)$. 
A remoção de cobre por tonelada de tubérculo nas águas foi de $0,86 \mathrm{~g}$, valor esse, inferior ao relatado por Fontes (1997) de 1,3 a 2,0 $\mathrm{g} \mathrm{t}^{-1}$, porém, na safra da seca, a remoção foi de $1,47 \mathrm{~g} \mathrm{t}^{-1}$ que confirma o resultado do autor.

O acúmulo de cobre nas raízes, caules e folhas apresentou significância $(P<0,01)$ e ajustou-se ao modelo quadrático de regressão nas duas safras, exceção para as raízes da safra das águas e os tubérculos das duas safras, que apresentaram significância $(P<0,01)$, com ajuste ao modelo linear (Figura 20). Os valores de acúmulo de cobre nas folhas de 90 e 97 DAP, na safra das águas, não foram incluídos na análise estatística, pois foi realizada uma pulverização com $2 \mathrm{~kg} \mathrm{ha}^{-1}$ de oxicloreto de cobre (Recop) um dia antes de 90 DAP, e os resultados indicavam uma nítida contaminação nas folhas, logo, esses valores também não foram incluídos na análise estatística do acúmulo total do cobre.

Na safra das águas, o acúmulo máximo de cobre nas raízes, caules e folhas ocorreu aos 111, 85 e 80 DAP e foi de 10,93; 69,68 e 288,65 $\mu$ planta $^{-1}(0,46 ; 2,9$ e $\left.12,03 \mathrm{~g} \mathrm{ha}^{-1}\right)$, respectivamente e, esses valores, corresponderam na safra da seca, a 7,75; 80,94 e 245,52 $\mu$ planta $^{-1}\left(0,32 ; 3,37\right.$ e 10,23 $\left.\mathrm{g} \mathrm{ha}^{-1}\right)$ aos 56, 55 e 49 DAP. Nas duas safras, o máximo acúmulo de cobre nas raízes, caules e folhas ocorreu no estádio de enchimento de tubérculos, com exceção das raízes, na safra das águas. Paula et al. (1986b) observaram valores diferentes nesses órgãos, para as cultivares 'Achat' $\left(0,42 ; 2,5\right.$ e 2,08 $\left.\mathrm{g} \mathrm{ha}^{-1}\right)$ e 'Mantiqueira' (0,52; 2,72 e 3,17 $\left.\mathrm{g} \mathrm{ha}^{-1}\right)$.

Quanto aos tubérculos, o acúmulo máximo de cobre foi de 746,41 $\mu \mathrm{g}_{\text {planta }}{ }^{-1}$ $\left(31,1 \mathrm{~g} \mathrm{ha}^{-1}\right)$, aos 111 DAP na safra das águas e, de 920,86 $\mu \mathrm{g} \mathrm{planta}^{-1}\left(38,37 \mathrm{~g} \mathrm{ha}^{-1}\right)$ aos 90 DAP na safra da seca, ambos na maturação. Valores observados por Paula et al. (1986b) foram bem menores, para 'Achat' (13 $\left.\mathrm{g} \mathrm{ha}^{-1}\right)$ e 'Mantiqueira' (16,03 $\left.\mathrm{g} \mathrm{ha} \mathrm{h}^{-1}\right)$.

$\mathrm{Na}$ safra das águas, a taxa maior de acúmulo de cobre nas raízes e caules ocorreram no enchimento de tubérculos, de 56 a 62 e de 84 a 90 DAP, respectivamente e nas folhas e tubérculos, na maturação, de 98 a 104 DAP.

Já na safra da seca, a taxa maior de acúmulo de cobre nos caules ocorreu no crescimento vegetativo, da emergência até 20 DAP. Para as raízes ocorreu na maturação, de 84 a 90 DAP e para as folhas e tubérculos, no final do enchimento de tubérculos, de 63 a 69 DAP. 
\Safra das águas - Safra da seca
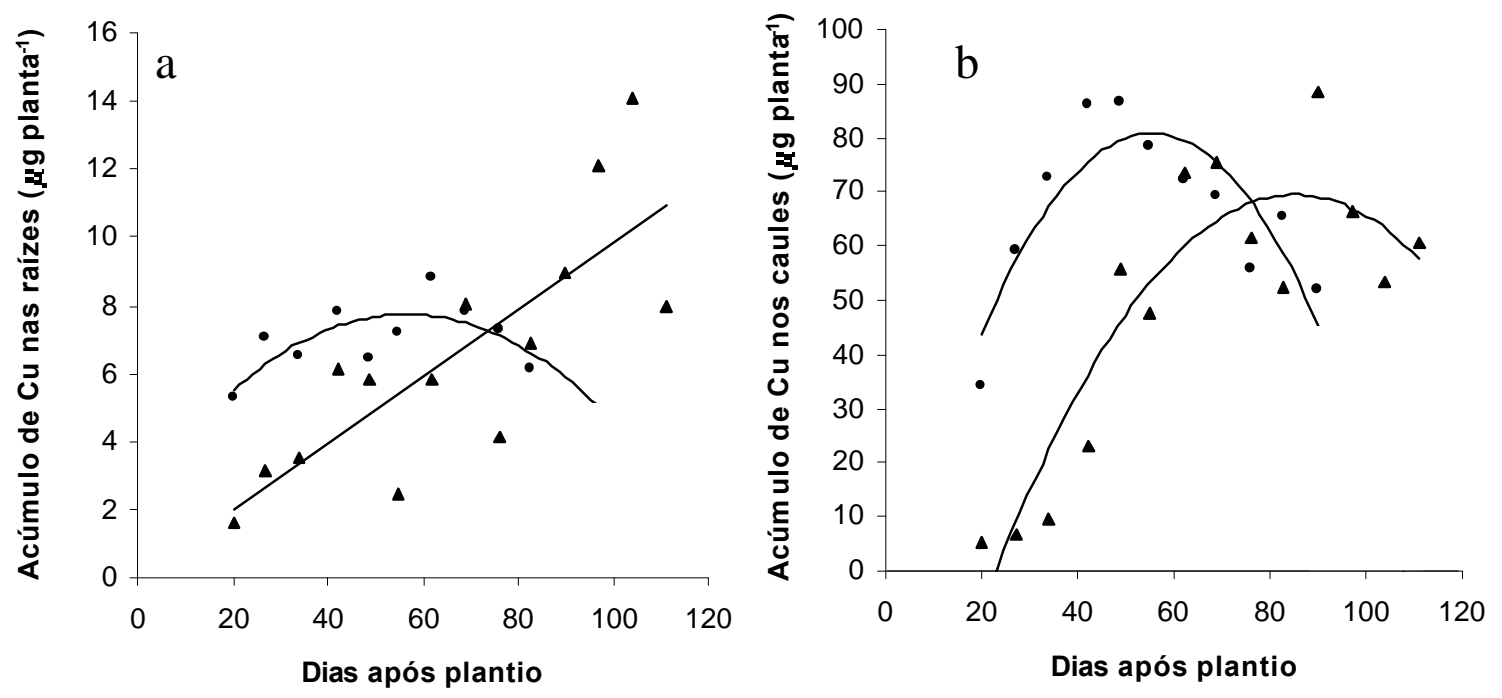
- $y=0,0981 x+0,04230$
$\left(R^{2}=0,64\right)$
- $y=-0,0017 x^{2}+0,1905 x+2,3751 \quad\left(R^{2}=0,53\right)$

\ $y=-0,01809 x^{2}+3,06997 x-60,5384 \quad\left(R^{2}=0,82\right)$

- $y=-0,02941 x^{2}+3,2512 x-8,9171 \quad\left(R^{2}=0,73\right)$
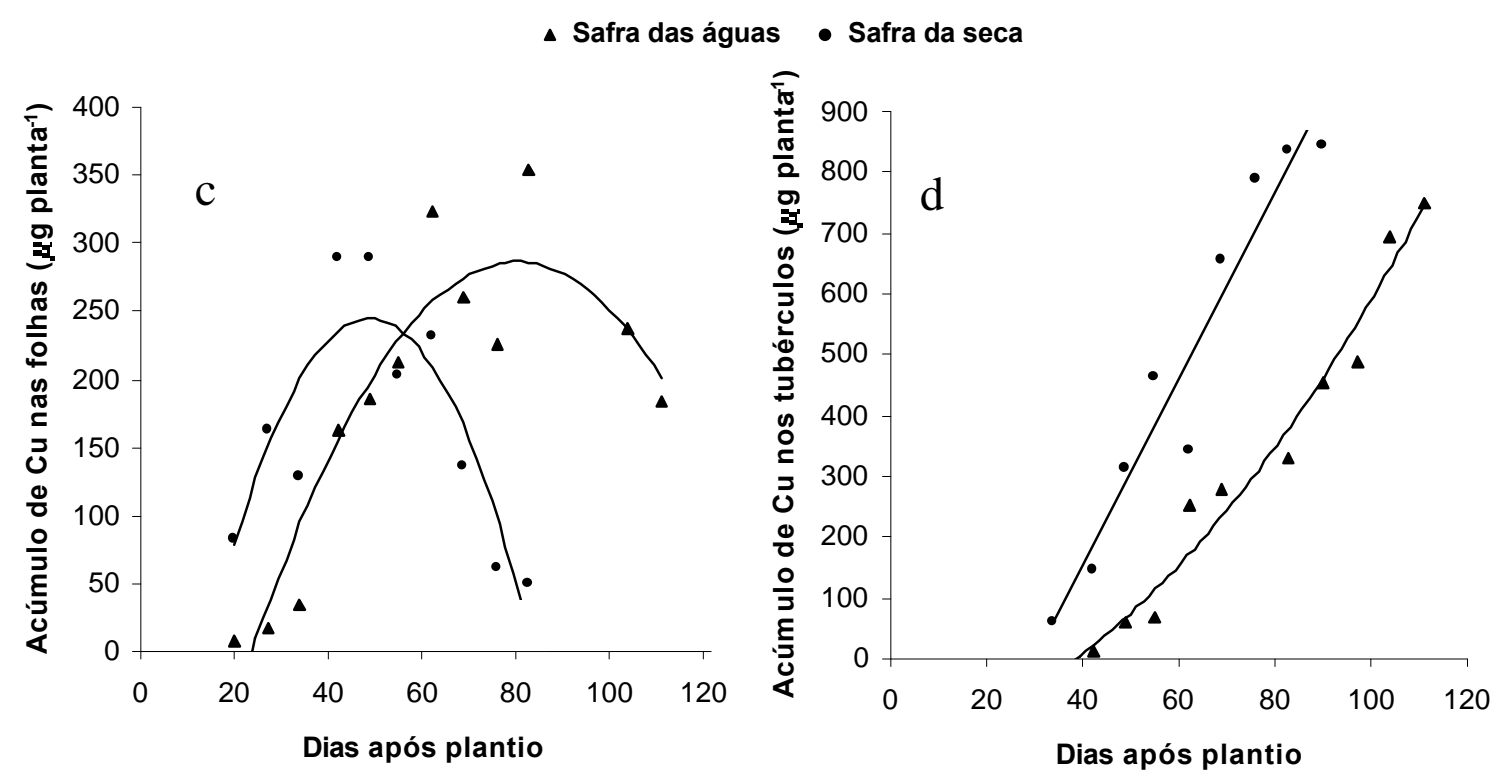

$$
\begin{array}{cc}
\Delta y=-0,0915 x^{2}+14,6071 x-294,1055 & \left(R^{2}=0,86\right) \\
\text { - } y=-0,1989 x^{2}+19,4230 x-228,6882 & \left(R^{2}=0,78\right)
\end{array}
$$

$$
\begin{array}{ll}
\text { \ } y=0,0729 x^{2}-0,4070 x-75,8039 & \left(R^{2}=0,97\right) \\
\text { - } y=15,3559 x-461,1687 & \left(R^{2}=0,93\right)
\end{array}
$$

Figura 20 - Cobre acumulado nos órgãos da batateira ao longo do ciclo ( $\mu$ g planta $\left.{ }^{-1}\right)$ : raízes (a), caules (b), folhas (c) e tubérculos (d). 


\subsubsection{Ferro}

O acúmulo total de ferro apresentou significância $(P<0,01)$ e ajustou-se ao modelo quadrático de regressão, nas duas safras (Figura 21).

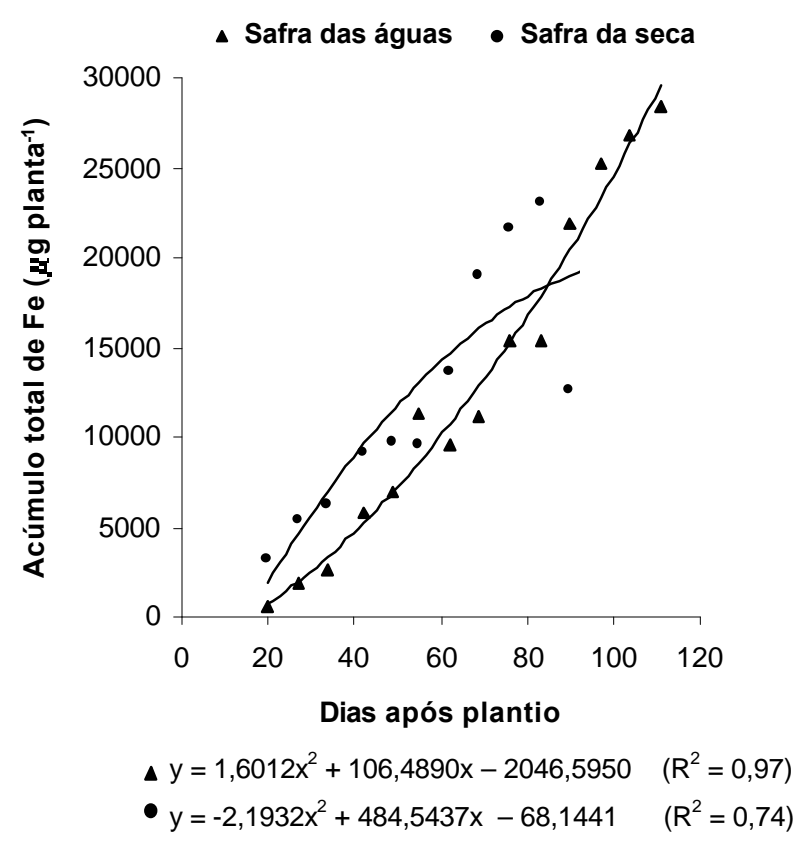

Figura 6 - Ferro total acumulado na batateira ao longo do ciclo nas safras das águas e da seca $\left(\mu\right.$ planta $\left.^{-1}\right)$.

$\mathrm{Na}$ safra das águas, o acúmulo máximo total de ferro foi de 29.502,53 $\mu \mathrm{g} \mathrm{planta}^{-1}$ (1.229 $\left.\mathrm{g} \mathrm{ha}^{-1}\right)$ aos $111 \mathrm{DAP}$, maior do que na safra da seca, de 18.969,7 $\mu \mathrm{g} \mathrm{planta}^{-1}\left(790 \mathrm{~g} \mathrm{ha}^{-1}\right)$ aos $92 \mathrm{DAP}$, sendo que ambos ocorreram na maturação. Paula et al. (1986b) observaram valores de acúmulo próximos aos da safra da seca, para as cv. 'Mantiqueira' (710 $\left.\mathrm{g} \mathrm{ha}^{-1}\right)$ e 'Achat' $\left(760 \mathrm{~g} \mathrm{ha}^{-1}\right)$.

A exportação de ferro na safra das águas foi de 32\% (392 $\left.\mathrm{g} \mathrm{ha}^{-1}\right)$ do acúmulo máximo de ferro total e, na safra da seca, foi de 45\% (358 $\left.\mathrm{g} \mathrm{ha}^{-1}\right)$. Paula et al. (1986b) encontraram valores menores de exportação para as cv. 'Mantiqueira' (112 g ha-1) e 'Achat' (111 $\left.\mathrm{g} \mathrm{ha}^{-1}\right)$.

A remoção de ferro por tonelada de tubérculo na safra das águas e na safra da seca $(10,76$ e $14,74 \mathrm{~g}$ respectivamente) foram bem superiores aos relatados por Fontes (1997) de 2,0 a 4,0 $\mathrm{g} \mathrm{t}^{-1}$. 
Para o acúmulo de ferro nas raízes e folhas, nas duas safras e nos caules na safra das águas, o modelo quadrático de regressão foi o mais adequado, já para os caules da safra da seca e os tubérculos nas duas safras, os resultados ajustaram-se ao modelo linear de regressão (Figura 22).

Na safra das águas, o acúmulo máximo de ferro nas raízes, caules e folhas ocorreu aos 65, 111 e 111 DAP e foi de 1.301,02; 3.613,55 e 15.565,72 $\mu$ g planta $^{-1}$ $\left(54,21 ; 150,27\right.$ e $\left.648,58 \mathrm{~g} \mathrm{ha}^{-1}\right)$, respectivamente, enquanto esses valores corresponderam na safra da seca, a 1.003,32, 4.007,46 e 9.143,12 $\mu$ planta $^{-1}$ $\left(41,81 ; 166,98\right.$ e 380,97 $\left.\mathrm{g} \mathrm{ha}^{-1}\right)$ e ocorreram aos 44, 90 e 83 DAP. Nas duas safras, o acúmulo máximo de ferro nos caules e folhas ocorreu no estádio de maturação, e nas raízes, no enchimento de tubérculos. Paula et al. (1986b) observaram valores diferentes de acúmulo máximo nas raízes, caules e folhas, para nas cultivares 'Achat' e 'Mantiqueira' (185, 126 e $347 \mathrm{~g} \mathrm{ha}^{-1}$ e, 148, 127 e $338 \mathrm{~g} \mathrm{ha}^{-1}$ respectivamente).

Quanto aos tubérculos, o acúmulo máximo de ferro foi de 9.638,57 $\mu \mathrm{g}_{\text {planta }}{ }^{-1}$ $\left(401,61 \mathrm{~g} \mathrm{ha}^{-1}\right), 111$ DAP na safra das águas e, de 10.171,67 $\mu \mathrm{g} \mathrm{planta}^{-1}\left(423,82 \mathrm{~g} \mathrm{ha}^{-1}\right)$ aos 90 DAP na safra da seca, ambos na maturação, diferentes dos valores observados por Paula et al. (1986b), para a cv. 'Achat' (111 $\left.\mathrm{g} \mathrm{ha}^{-1}\right)$ e 'Mantiqueira' (112 $\left.\mathrm{g} \mathrm{ha}^{-1}\right)$.

$\mathrm{Na}$ safra das águas, a taxa maior de acúmulo de ferro nas raízes ocorreu na tuberização. Nos caules, ocorreu na maturação, de 98 a 104 DAP e nas folhas e tubérculos, no enchimento de tubérculos, de 84 a 90 e de 70 a 76 DAP, respectivamente.

Já na safra da seca, a taxa maior de acúmulo de ferro nas raízes ocorreu no crescimento vegetativo, da emergência até 20 DAP, nos caules e tubérculos ocorreu no final do enchimento de tubérculos, de 63 a 69 DAP e nas folhas, na maturação, de 77 a 83 DAP. 
\Safra das águas - Safra da seca
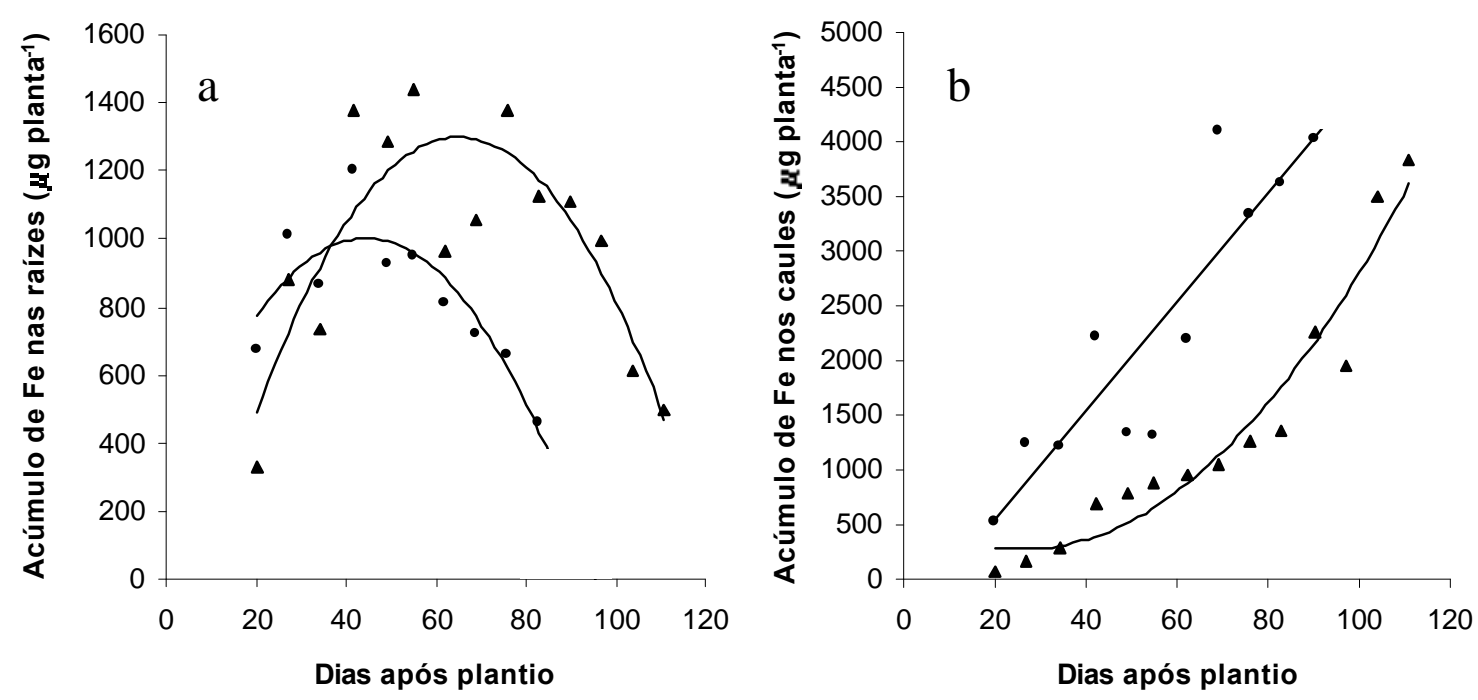

$\begin{array}{ll}\Delta y=-0,3968 x^{2}+51,6204 x-377,7885 & \left(R^{2}=0,72\right) \\ \text { - } y=-0,3860 x^{2}+34,3525 x-239,0934 & \left(R^{2}=0,77\right)\end{array}$
$\Delta y=0,4674 x^{2}-24,8665 x-614,6654$
$\left(R^{2}=0,93\right)$
- $y=49,3338 x-432,5762$
$\left(R^{2}=0,79\right)$

- Safra das águas - Safra da seca

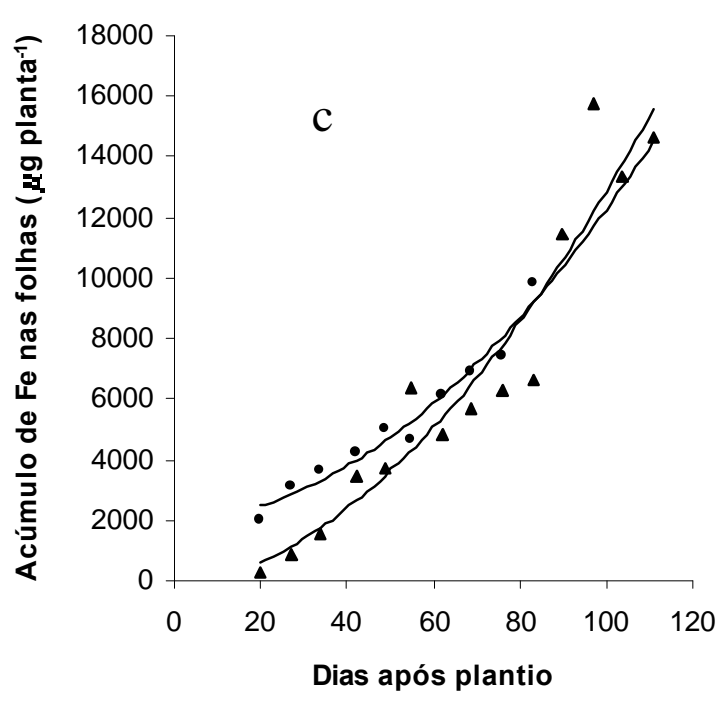

\ $y=1,0299 x^{2}+29,5599 x-404,7819 \quad\left(R^{2}=0,91\right)$

- $y=0,9265 x^{2}+10,1550 x-1917,7567\left(R^{2}=0,96\right)$

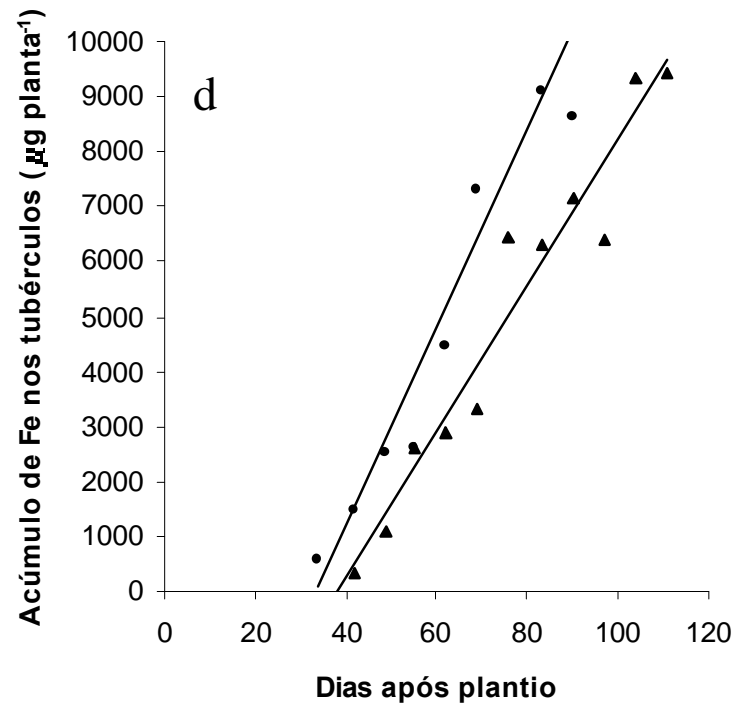

\ $y=131,5785 x-4966,65$

$\left(R^{2}=0,94\right)$

- $y=178,4522 x-5889,0268$

$\left(R^{2}=0,88\right)$

Figura 22 - Ferro acumulado nos órgãos da batateira ao longo do ciclo ( $\mu$ g planta $\left.{ }^{-1}\right)$ : raízes (a), caules (b), folhas (c) e tubérculos (d). 


\subsubsection{Manganês}

O acúmulo total de manganês apresentou significância $(P<0,01)$ e ajustando-se ao modelo quadrático de regressão, nas duas safras (Figura 23).

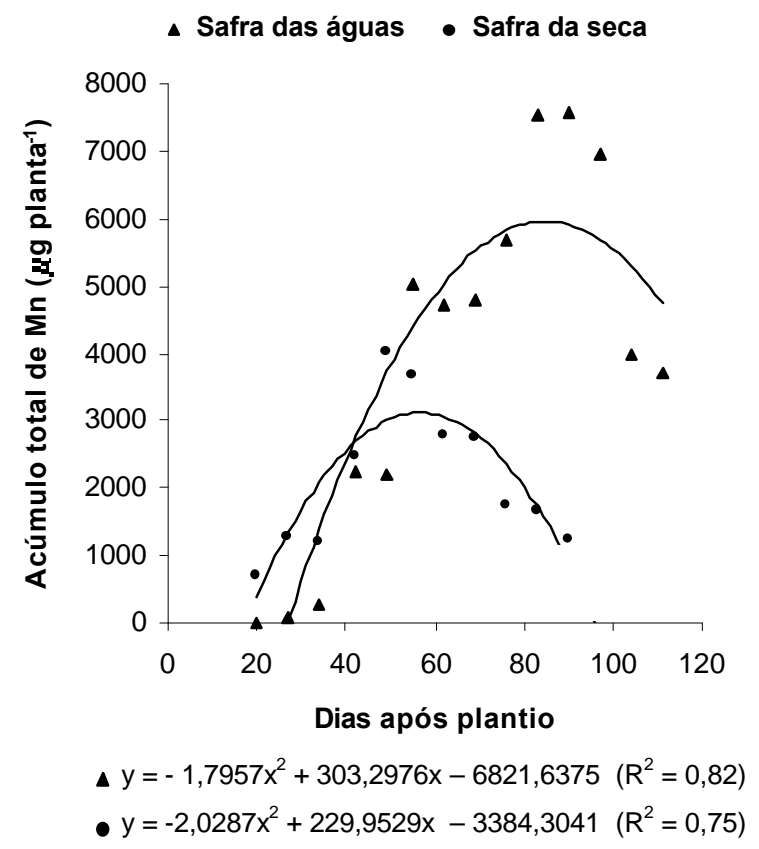

Figura 23 - Manganês total acumulado na batateira ao longo do ciclo, nas safras das águas e da seca ( $\mu$ g planta $\left.{ }^{-1}\right)$.

$\mathrm{Na}$ safra das águas, o acúmulo máximo de manganês total, de $5.984,75 \mu$ planta $^{-1}$ (250 $\mathrm{g} \mathrm{ha}^{-1}$ ) aos 84 DAP e foi maior que o da safra da seca, que foi de $3.131,91 \mu$ planta $^{-1}\left(130 \mathrm{~g} \mathrm{ha}^{-1}\right.$ ) aos 57 DAP, sendo que ambos ocorreram no enchimento de tubérculos. Paula et al. (1986b) observaram um acúmulo máximo de manganês de 140 e $104 \mathrm{~g} \mathrm{ha}^{-1}$ nas cv. 'Mantiqueira' e 'Achat', respectivamente.

A exportação de manganês na safra das águas foi de $28 \mathrm{~g} \mathrm{ha}^{-1}$ e correspondeu a $11 \%$ do acúmulo máximo total, já na safra da seca, a exportação foi de $16,5 \mathrm{~g} \mathrm{ha}^{-1}$, cerca de $13 \%$ do acúmulo máximo. Pode-se observar, que a exportação ( $\left.\mathrm{g} \mathrm{ha}^{-1}\right)$ na safra das águas foi maior do que na safra da seca, porém a proporção (\%) em relação ao total se manteve. Paula et al. (1986b) observou exportações próximas ̊̀ deste experimento, para as cv. 'Mantiqueira' (25,9 $\left.\mathrm{g} \mathrm{ha}^{-1}\right)$ e 'Achat' (19,93 $\left.\mathrm{g} \mathrm{ha}^{-1}\right)$. 
A remoção de manganês por tonelada de tubérculo foi de $0,77 \mathrm{~g}$ na safra das águas e 0,69 $\mathrm{g}$ na safra da seca. Esses valores foram bem inferiores aos relatados por Fontes (1997), que eram de 1,7 a 2,1 $\mathrm{g} \mathrm{t}^{-1}$.

O acúmulo de manganês nas raízes, caules, folhas e tubérculos, apresentou significância $(P<0,01)$ e ajustou-se ao modelo quadrático de regressão, exceção para os caules na safra da seca, que apresentou significância $(P<0,01)$, ajustando-se ao modelo linear de regressão (Figura 24).

Na safra das águas, o acúmulo máximo de manganês nas raízes, caules, folhas e tubérculos ocorreu aos 70, 93, 80 e 111 DAP e foi de 43,16; 527,07; 5.085,28 e $789,05 \mu$ planta $^{-1}\left(1,80 ; 21,96 ; 211,89\right.$ e 32,88 $\left.\mathrm{g} \mathrm{ha}^{-1}\right)$, respectivamente, sendo que esses valores corresponderam na safra da seca, a 54,4; 760,87; 2.459,41 e 424,13 $\mu \mathrm{g}$ planta $^{-1}\left(2,27 ; 31,70 ; 102,48\right.$ e 17,67 $\left.\mathrm{g} \mathrm{ha}^{-1}\right)$ aos 41, 90, 52 e 90 DAP. O acúmulo máximo de manganês nos caules e tubérculos ocorreu no estádio de maturação. Nas raízes e folhas, ocorreu no enchimento de tubérculos, nas duas safras. Paula et al. (1986b) observaram valores diferentes de acúmulo máximo de manganês nas raízes, caules, folhas e tubérculos para as cultivares 'Achat' $(3,2 ; 13,32,57,7$ e 19,93 g ha-1, respectivamente) e 'Mantiqueira' (4,28; 25,0; 85,22 e 25,9 $\mathrm{g} \mathrm{ha}^{-1}$, respectivamente).

Na safra das águas, a taxa maior de acúmulo de manganês nas raízes ocorreu no crescimento vegetativo, de 20 a 27 DAP, nos caules e tubérculos na maturação, de 91 a 97 DAP e nas folhas, no início do enchimento de tubérculos, de 49 a 55 DAP.

Já na safra da seca, a taxa maior de acúmulo de manganês nas raízes ocorreu no crescimento vegetativo, da emergência até 20 DAP, nas folhas e tubérculos ocorreu no enchimento de tubérculos, de 42 a 48 e de 49 a 55 DAP e, nos caules, na maturação, de 84 a 90 DAP. 


\section{- Safra das águas - Safra da seca}
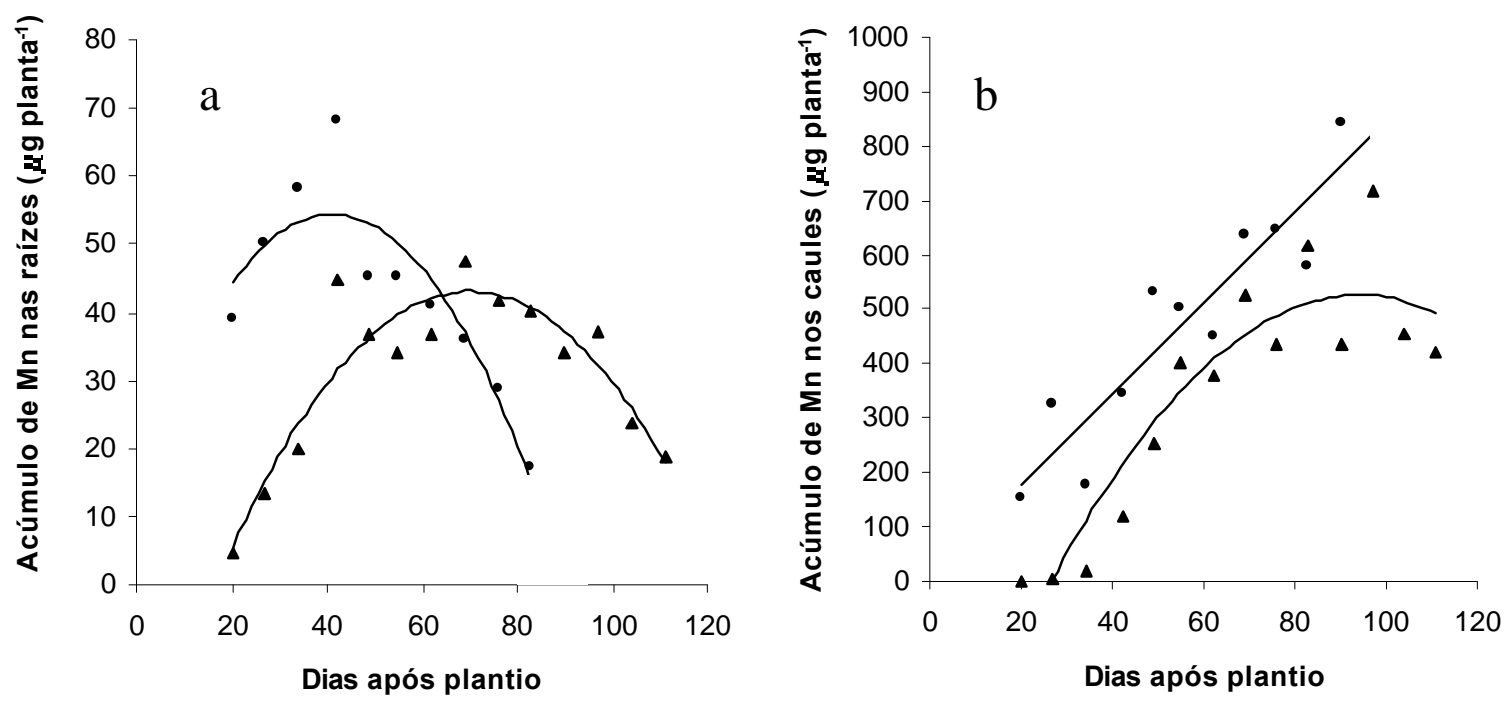
\ $y=-0,01496 x^{2}+2,0939 x-30,0989 \quad\left(R^{2}=0,84\right)$
- $y=-0,1170 x^{2}+21,8982 x-497,4113 \quad\left(R^{2}=0,85\right)$
- $y=-0,0224 x^{2}+1,8419 x+16,58005,5847 \quad\left(R^{2}=0,81\right)$
- $y=8,2897 x+14,7893$
$\left(R^{2}=0,85\right)$
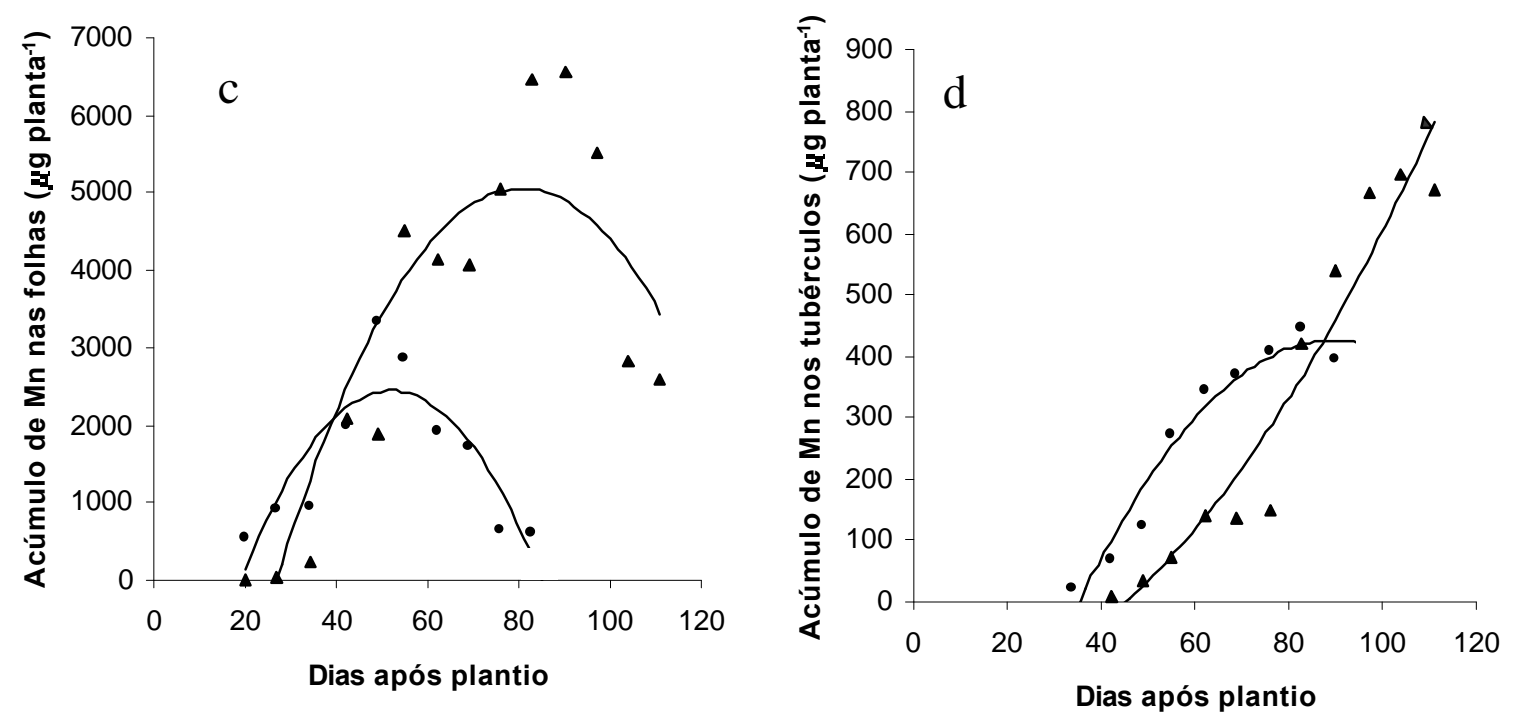

$\begin{array}{lll}\text { A } y=-1,7735 x^{2}+284,8059 x-6348,7892 & \left(R^{2}=0,79\right) \\ \text { - } y=-2,2619 x^{2}+235,0608 x-3647,6210 & \left(R^{2}=0,74\right)\end{array}$

$\begin{array}{ll}\Delta y=0,1026 x^{2}-4,1249 x-16,9307 & \left(R^{2}=0,89\right) \\ \text { • } y=-0,1454 x^{2}+25,8941 x-728,7487 & \left(R^{2}=0,96\right)\end{array}$

Figura 24 - Manganês acumulado nos órgãos da batateira ao longo do ciclo (mg planta ${ }^{-1}$ ): raízes (a), caules (b), folhas (c) e tubérculos (d). 


\subsubsection{Zinco}

O acúmulo total de zinco apresentou significância $(P<0,01)$ ajustando-se ao modelo linear de regressão, nas duas safras (Figura 25).

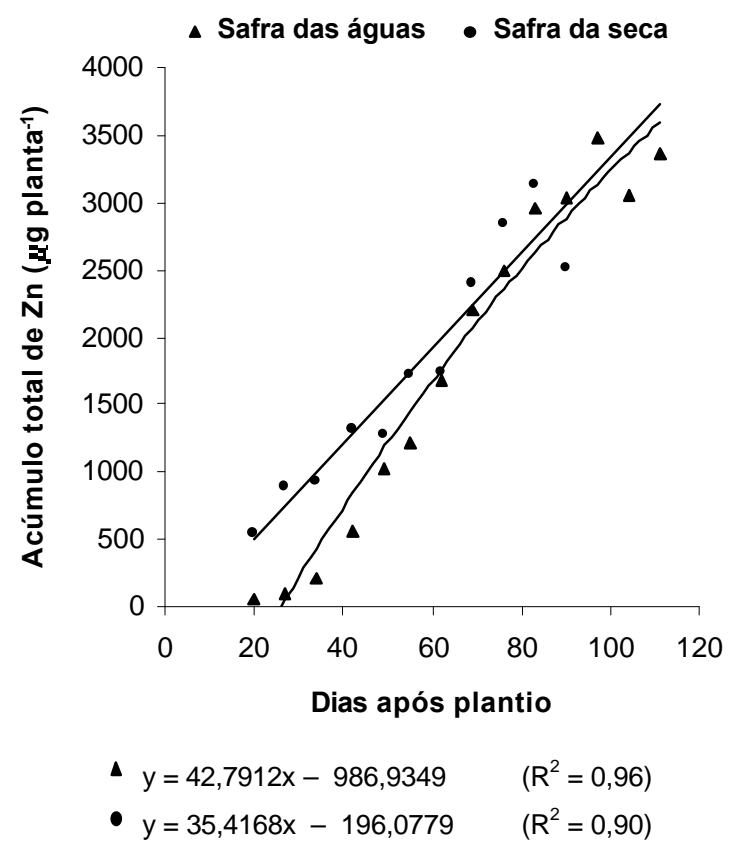

Figura 25 - Zinco total acumulado na batateira ao longo do ciclo nas safras das águas e da seca $\left(\mu\right.$ planta $\left.^{-1}\right)$.

O acúmulo máximo de zinco total na safra das águas, foi de 3.762,89 $\mathrm{g} \mathrm{planta}^{-1}\left(156,8 \mathrm{~g} \mathrm{ha}^{-1}\right)$ aos $111 \mathrm{DAP}$, sendo maior do que na safra da seca, que foi de 2.991,44 $\mu \mathrm{g}_{\text {planta }}^{-1}\left(124,6 \mathrm{~g} \mathrm{ha}^{-1}\right)$, aos 90 DAP e, nas duas safras, o acúmulo máximo de zinco total ocorreu na maturação. Paula et al. (1986b) observou valores menores do que os deste experimento, para as cv. 'Mantiqueira' (86 $\mathrm{g} \mathrm{ha}^{-1}$ ) e 'Achat' (38 $\left.\mathrm{g} \mathrm{ha}^{-1}\right)$.

A exportação de zinco na safra da seca $\left(97,2 \mathrm{~g} \mathrm{ha}^{-1}\right)$ foi maior do que na safra das águas (91,5 $\left.\mathrm{g} \mathrm{ha}^{-1}\right)$, apesar do acúmulo máximo ser menor. Paula et al. (1986b) verificaram valores bem menores, para as cv. 'Mantiqueira' e 'Achat' (63 e $24 \mathrm{~g} \mathrm{ha}^{-1}$, respectivamente).

A remoção de zinco por tonelada de tubérculo na safra das águas $(2,51 \mathrm{~g})$ foi menor do que na safra da seca $(4,05 \mathrm{~g})$. Esses valores são próximos aos relatados por 
Fontes (1997), que foi de 3,0 a 5,0 $\mathrm{g} \mathrm{t}^{-1}$, porém, Feltran \& Lemos (2001) observaram valores menores que os deste experimento, para as cultivares 'Asterix' $\left(1,880 \mathrm{~g} \mathrm{t}^{-1}\right)$, 'Laguna' (1,592 $\left.\mathrm{g} \mathrm{t}^{-1}\right)$, 'Picasso' (1,648 $\left.\mathrm{g} \mathrm{t}^{-1}\right)$ e 'Solide' (1,706 $\left.\mathrm{g} \mathrm{t}^{-1}\right)$.

O acúmulo de zinco nas raízes, caules e folhas apresentou significância $(P<0,01)$, ajustando-se ao modelo quadrático de regressão, enquanto nos tubérculos, ajustou-se ao modelo linear de regressão (Figura 26).

Na safra das águas, o acúmulo máximo de zinco nas raízes, caules e folhas ocorreu aos 69, 86, 96 e 111 DAP e foi de 14,93; 585,87; 690,96 e $2.325,84 \mu$ g planta $^{-1}\left(0,62 ; 24,41 ; 28,79\right.$ e $\left.96,91 \mathrm{~g} \mathrm{ha}^{-1}\right)$, respectivamente, sendo que esses valores corresponderam na safra da seca, a 20; 615,59; 347,64 e $2.668,51 \mu$ g planta $^{-1}\left(0,83 ; 25,65 ; 14,49\right.$ e $\left.111,19 \mathrm{~g} \mathrm{ha}^{-1}\right)$ aos 44, 51, 35 e 90 DAP. Nas duas safras, o acúmulo máximo de zinco nas raízes, caules e folhas ocorreu no estádio de enchimento de tubérculos, com exceção das folhas, na safra das águas, que ocorreu na maturação. Paula et al.(1986b) observaram valores diferentes para acúmulo máximo de zinco nas raízes, caules, folhas e tubérculos, para as cultivares 'Achat' $\left(0,87 ; 6,53 ; 5,79\right.$ e $\left.24 \mathrm{~g} \mathrm{ha}^{-1}\right)$ e Mantiqueira' $\left(1,86 ; 8,24 ; 12,14\right.$ e $63 \mathrm{~g} \mathrm{ha}^{-1}$, respectivamente).

Na safra das águas, a taxa maior de acúmulo de zinco nas raízes e caules ocorreu na tuberização (35 a 41 e 42 a 48 DAP, respectivamente), enquanto nas folhas e tubérculos, ocorreu na maturação (77 a 83 e 63 a 69 DAP, respectivamente).

Já na safra da seca, a taxa maior de acúmulo de zinco nas raízes e caules ocorreu no crescimento vegetativo, da emergência até 20 DAP, nas folhas ocorreu na tuberização, de 20 a 27 DAP e nos tubérculos, ocorreu na maturação, de 70 a 76 DAP. 
\Safra das águas • Safra da seca
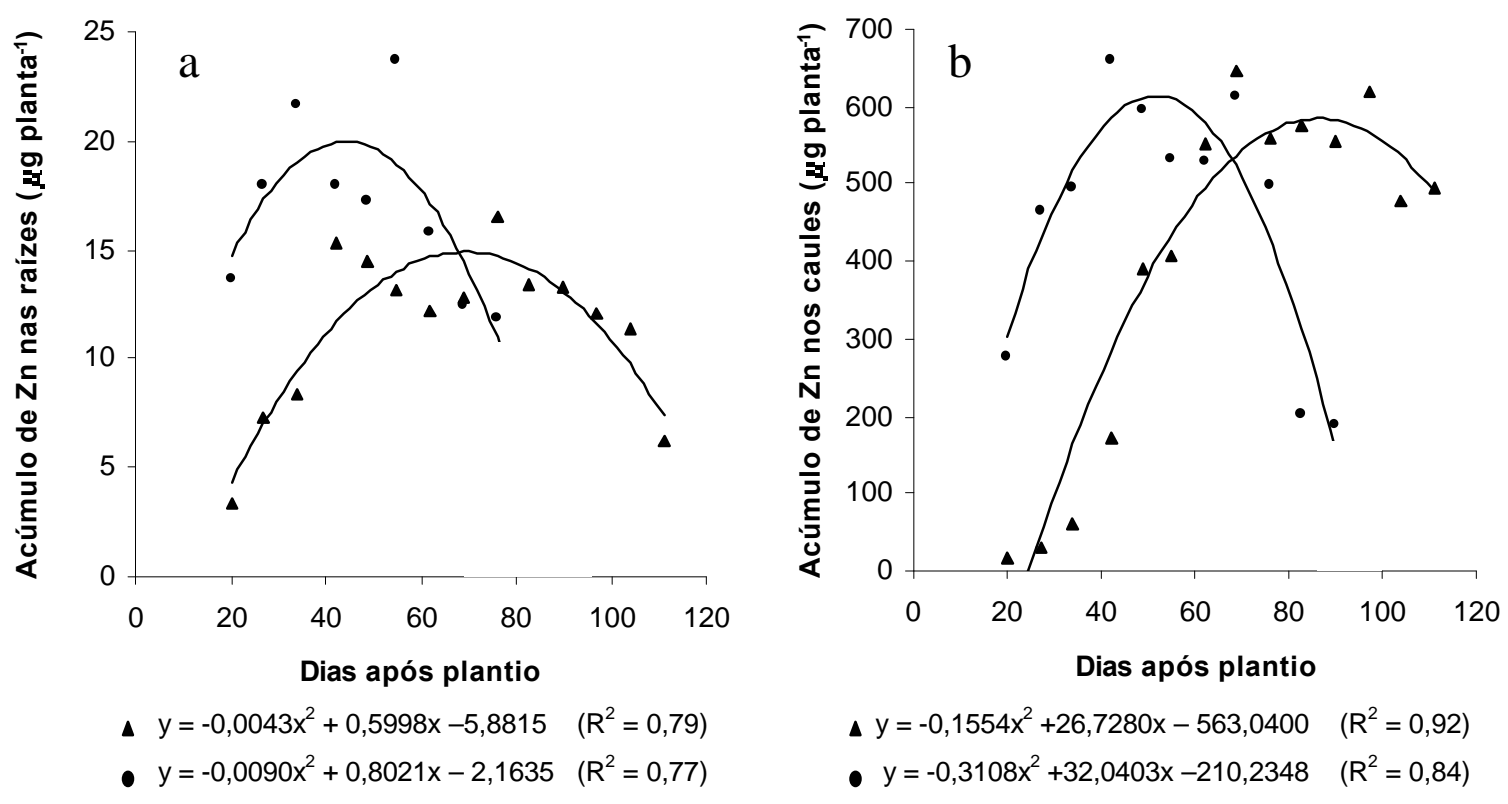

- $y=-0,3108 x^{2}+32,0403 x-210,2348 \quad\left(R^{2}=0,84\right)$

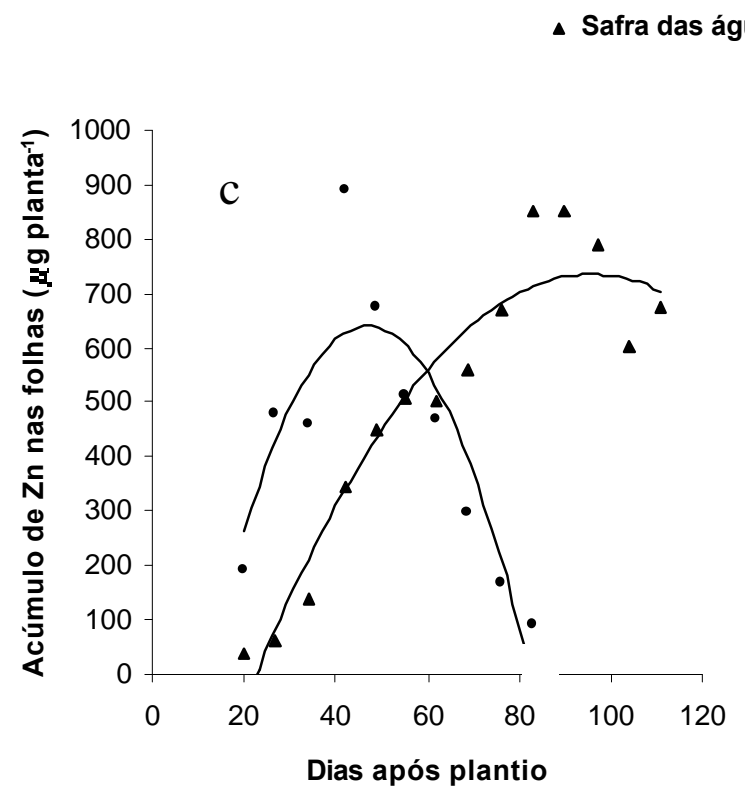

- Safra da seca

$$
\begin{array}{ll}
\Delta y=-0,1370 x^{2}+26,235 x-520,780 & \left(R^{2}=0,92\right) \\
\text { - } y=-0,1052 x^{2}+7,2828 x+221,6206 & \left(R^{2}=0,71\right)
\end{array}
$$

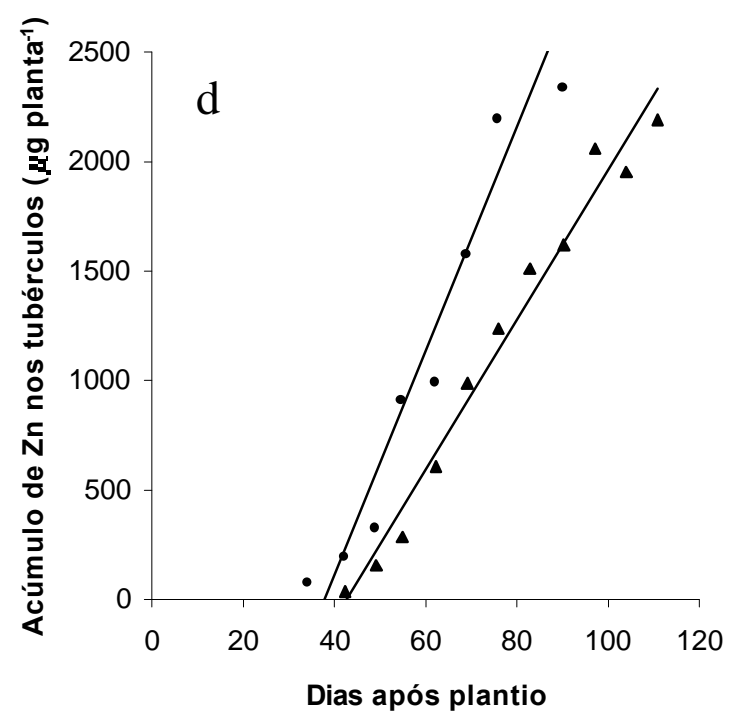
\ $y=33,5594 x-1399,2471$
$\left(R^{2}=0,98\right)$
- $y=50,5164 x-1877,9635$
$\left(R^{2}=0,93\right)$

Figura 26 - Zinco acumulado nos órgãos da batateira ao longo do ciclo ( $\mu$ g planta ${ }^{-1}$ ): raízes (a), caules (b), folhas (c) e tubérculos (d). 


\section{CONCLUSÕES}

- A safra das águas produziu mais massa de material seco que a safra da seca.

- O acúmulo de massa da planta foi influenciado pelos estádios da cultura e pela safra: vegetativo $(2,2$ e 5,2\%) < tuberização (13 e 20\%) < enchimento de tubérculos (90 e 95\%) < maturação (100 e 100\%) para a safra das águas e da seca, respectivamente.

- A sequêencia de acúmulo máximo na safra das águas foi: nitrogênio > potássio $>$ cálcio $>$ fósforo $>$ magnésio $>$ enxofre $>$ ferro $>$ manganês $>$ zinco $>$ boro $>$ cobre. Na safra da seca, o potássio trocou de posição com o nitrogênio e o fósforo com o cálcio.

- O acúmulo máximo dos nutrientes depende da safra e do nutriente: nitrogênio (140 e 119); fósforo (17,6 e15,2); potássio (134 e 139); cálcio (21,7 e 14,6); magnésio (14,3 e 6,9); enxofre (10,8 e 14,6) em kg ha ${ }^{-1}$; boro (107 e 84,3); cobre (43,5 e 38,9); ferro (1.229 e 790); manganês (250 e 130); zinco $\left(156,6\right.$ e 124,6) em g ha-1 ${ }^{-1}$ para as safras das águas e da seca, respectivamente.

- A seqüência de exportação de nutrientes na safra das águas foi: nitrogênio $>$ potássio $>$ fósforo $>$ enxofre $>$ magnésio $>$ cálcio $>$ ferro $>$ zinco $>$ boro $>$ manganês $>$ cobre. Na safra da seca, potássio trocou de posição nitrogênio e cobre com manganês. 


\section{REFERÊNCIAS BIBLIOGRÁFICAS}

ASSOCIAÇÃO NACIONAL PARA DIFUSÃO DE ADUBOS. Anuário Estatístico. São Paulo: ANDA, 2000. 252p.

BEUKEMA, H.P.; ZAAG, van der. Introduction to potato production. Amsterdam: Pudoc, 1990. 208p.

BIEMOND, H.; VOS, J. Effects of nitrogen onthe development and growth of potato plant. 2. The partitioning of dry matter, nitrogen and nitrate. Annals of Botany, v.70, p.37-45, 1992.

CAROLUS, R.L. Chemical estimations of the weekly nutrient level of a potato crop. American Potato Journal, v.24, p.141-153, 1937.

CARPENTER, P.N. Mineral acumulation in potato plants. Orono: Maine Agricultural Experiment Station, 1957. 23p. (Bulletin, 562).

CHAPMAN, K.S.R.; SPARROW, P.R.; HARDMAN, D.N. Potassium nutrition of Kennebec and Russet Burbank potatoes in Tasmania: effect of soil and fertilizer potassium on yield, petiole and tuber potassium concentrations, and tuber quality. Australian Journal of Experimental Agriculture, v.32, p.521-527, 1992.

CORASPE-LÉÓN, H.M. Aplicações foliares de ácido giberélico e seus efeitos sobre a dormência de batata-semente (Solanum tuberosum L.) cv. Atlantic. Piracicaba, 1995. 91p. Dissertação (Mestrado) - Escola Superior de Agricultura "Luiz de Queiroz", Universidade de São Paulo. 
ELMA CHIPS. Manual de recomendações técnicas para produção da variedade Atlantic. 5.ed. Itu, 2000. 15p.

ERREBI, M.; ROSEN, C.J.; GUPTA, S.C.; BIRONG, D.E. Potato yield response and nitrate leaching as influenced by nitrogen manegement. Agronomy Journal, v.90, p.10-15, 1998.

EWING, E.E. Potato. In: WIEN, H.C. The physiology of vegetable crops. CABI, 1997. p.295-344.

EZETA, F.N.; McCOLLUM, R.E. Dry-matter production and nutrient uptake and removal by Solanum andigena in the Peruvian Andes. American Potato Journal, v.49, p.151-163, 1972.

FAGERIA, N.K.; BALIGAR, V.C.; JONES, C.A. Growth and mineral nutrition of field crops. 2.ed. New York: Marcel Dekker, 1997. 624p.

FELTRAN, J.C.; LEMOS, L.B. Acúmulo de nutrientes na parte aérea e nos tubérculos em cultivares de batata (Solanum tuberosum L.). In: ENCONTRO NACIONAL DE PRODUÇÃO E ABASTECIMENTO DE BATATA, 11; SEMINÁRIO NACIONAL DE BATATA SEMENTE, 7., Uberlândia, 2001. Resumos expandidos. Uberlândia: ABBA, 2001. p.21-25.

FILGUEIRA, F.A.R. Novo manual de olericultura: agrotecnologia moderna na produção e comercialização de hortaliças. Viçosa: Ed. UFV, 2000. 402p.

FNP CONSULTORIA \& COMÉRCIO. Agrianual 2002: anuário da agricultura brasileira. São Paulo, 2002. p.190-201: Batata.

FONTES, P.C.R. Calagem e adubação da cultura da batata. Informe Agropecuário, v.20, n.197, p.42-52, 1999 
FONTES, R.R. Preparo do solo e adubação de plantio. In: LOPES, C.A.; BUSO, J.A. Cultivo da batata (Solanum tuberosum L.). Brasília: EMBRAPA/CNPH, 1997. 35p. (Instruções técnicas, 8).

GARGANTINI, H.; BLANCO,G.; GALLO, J.R.; NÓBREGA, S.A. Absorção de nutrientes pela batatinha. Bragantia, v.22, n.22, p.267-289, 1963.

GUASENA, H.P.M.; HARRIS, P.M. The effect of the time application of nitrogen and potassium on the growth of the second early potato, variety Craig's Royal. Journal of Agricultural Science, v.71, p.283-296,1968.

HAAG, P.H.; OLIVEIRA, G.D. de; BARBOSA, V.; SILVA NETO, J.M. de. Marcha de absorção de nutrientes pelo tomateiro (Lycopersicum esculentum Mill) destinado ao processamento industrial. In: HAAG, H.P.; MINAMI, K. Nutrição mineral de hortaliças. Campinas: Fundação Cargill, 1981. p.447-474.

HAEDER, H.E.; BERINGER, H. Potato. Potencial productivity of field crops under different environments. Philippines: IRRI, p.307-317, 1983.

HANG, A.N.; MILLER, D.E. Yield and phisiological responses of potato todeficit, high frequency sprinkler irrigation. Agronomy Journal, v.78, p.436-440, 1986.

HARRIS, P. The Potato Crop: the scientific basis for improvement. London: Chapman and Hall, 1992. 437p.

HAWKINS, A. Rate of absortion and translocation of mineral nutrients by potatoes in Aroostook County, Maine, and their relation to fertilizer practices. Journal of the American Society of Agronomy, v.38, n.8, p.667-681.

HOOKER, W.J. Compendium of potato diseases. Minnesota: American Phytopathological Society, 1986, p.1-6: the potato. 
JACKSON, R.D.; HADDOCK, J.L. Growth and mineral uptake of Russet Burbank potatoes. American Potato Journal, v.36, p.22-28, 1959.

JOERN, B.C.; VITOSH, M.L. Influence of applied nitrogen on potato. Part I: Yield, quality and nitrogen uptake. American Potato Journal, v.72, p.53-63, 1995.

KLEINKOPF, G.E.; WESTERMANN, D.T.; Dwelle. Dry matter production and nitrogen utilization by siz potato cultivars. Agronomy Journal, v.73, p.799-802, 1981.

KLEINKOPF, G.E.; WESTERMANN, D.T.; PAINTER, C.G. Nitrogen effects and Russet Burbank potato growth. IN: ANNUAL NORTHWEST FERTILIZER CONFERENCE, 30., Washington,1979. Proceedings. Sporkane: Northwest Plant Food Association, 1979. p.143-150.

KOLASA, K.M. The potato and human nutrition. American Potato Journal, v.70, p.375-384, 1993.

KRATZKE, M.G.; PALTA, J.P. Calcium accumulation in potato tubers: role of basal roots. Hortscience, v.21, n.4, p.1022-1024, 1986.

LOOM, C.D. van Effect of water stress on potato growth, development and yield. American Potato Journal, v.58, p.51-69, 1981.

LOPES, C.A. In: LOPES, C.A.; BUSO, J.A. Cultivo da batata (Solanum tuberosum L.). Brasília: EMBRAPA/CNPH, 1997. 35p. (Instruções técnicas, 8).

MALAVOLTA, E.; VITTI, G.C.; OLIVEIRA, S.A. de. Avaliação do estado nutricional das plantas: princípios e aplicações. 2.ed. Piracicaba: POTAFOS, 1997. 319p.

MANRIQUE, L.A. Potato production in the tropics: crop requirements. Journal of Plant Nutrition, v.15, p.2679-2728, 1992. 
MAAS, E.V.; HOFFMAN, G.V. Crop salt tolerance-current assessment. Journal of Irrigation and Drainage, v.103, p.115-134, 1977.

MEYER, R.D; MARCUM, D.B. Potato yield, petiole nitrogen and soil nitrogen response to water and nitrogen. Agronomy Journal, v.90, p.420-429, 1998.

OJALA, J.C.; STARK, J.C.; KLEINKOPF, G.E. Influence of irrigation and nitrogen management on potato yiled and quality. American Potato Journal, v.67, p.29-43, 1990.

PANIQUE, E.; KELLING, K.A.; SCHULTE, E.E. Potassium rate and source effects on potato yield, quality, and disease interaction. American Potato Journal, v.74, p.379-398, 1997.

PASCHOALINO, J.E. Prevenção do escurecimento em batatas frescas descascadas e fatiadas. ITAL, v.23, n.2, p.189-197, 1993.

PAULA, M.B.; FONTES, P.C.R., NOGUEIRA, F.D. Produção de matéria seca e absorção de macronutrientes por cultivares de batata. Horticultura Brasileira, v.4, n.1, p.10-16, 1986a.

PAULA, M.B.; FONTES, P.C.R., NOGUEIRA, F.D. Absorção de micronutrientes por cultivares de batata em presença e ausência de adubação. Horticultura Brasileira, v.4, n.2, p.3-8, 1986b.

PEREIRA, A.S. Composição química, valor nutricional e industrialização. In: REIFSCHNEIDER, F.J.B. Produção de batata. Brasília: Linha Gráfica, 1987. p.12-28.

RAIJ, B. van.; CANTARELLA, H.; QUAGGIO, J.A.; FURLANI, A.M.C. Recomendações de adubação e calagem para o Estado de São Paulo. 2.ed. Campinas: Instituto Agronômico, Fundação IAC, 1997. 285p. 
ROBERTS, S.; DOLE, R.E. Potassium nutrition of potatoes. In: MUNSON, R.D. Potassium in agriculture. Madison: American Society of Agronomy, 1985. p.799-818.

SAFFIGNA, P.G.; KEENEY, D.R. Nitrogen and chloride uptake by irrigated Russet Burbank potatoes. Agronomy Journal, v.69, p.258-264, 1977.

SARRUGE, J. R.; HAAG, H.P. Análises químicas em plantas. Piracicaba: Escola Superior de Agricultura " Luiz de Queiroz ". 1974. 54p.

SNACK FOOD ASSOCIATION. 50 Years: A Foundation for the Future. Alexandria: CTI Publications, 1987, p.10-41.

SOUSA, V.F. de.; COELHO, E.F. Manejo de fertirrigação em fruteiras. In: FOLEGATTI, M.V. (Coord.) Fertirrigação: flores, frutas e hortaliças. Guaíba: Agropecuária, 2001. v.2, cap.9, p.289-317.

VILLAS BÔAS, R.L.; ANTUNES, C.L.; BOARETTO, A.E.; SOUSA, V.F. de.; DUENHAS, L.H. Perfil da pesquisa e emprego da fertirrigação no Brasil. In: FOLEGATTI, M.V. (Coord.) Fertirrigação: flores, frutas e hortaliças. Guaíba: Agropecuária, 2001. v.2, cap.2, p.71-103.

VITTI, G.C.; BOARETTO, A.E.; PENTEADO, S.R. Fertlizantes e fertirrigação. In: SIMPÓSIO BRASILEIRO SOBRE FERTLIZANTES FLUÍDOS. 1., Piracicaba, 1993. Anais. Piracicaba: Associação Brasileira para Pesquisa da Potassa e do Fosfato, 1994. p.261-280.

VOS, J. The nitrogen response of potato (Solanum tuberosum L.) in the fiels: nitrogen uptake and yield, harvest index and nitrogen concentration. American Journal of Potato Research, v.40, p.237-248, 1997.

WESTERMANN, D.T.; KLEINKOPF, G.E. Nitrogen requirements of potatoes. Agronomy Journal, v.77, p.616-621, 1985. 
WESTCOTT, M.P.; STEWART, V.R.; LUND, R.E. Critical petiole nitrate levels in potato. Agronomy Journal, v.83, p.844-850, 1991.

WILLARD, M. Potato processing: Past, Present and Future. American Potato Journal, v.70, p. 405-418, 1993. 